bioRxiv preprint doi: https://doi.org/10.1101/2020.01.11.902908; this version posted April 16, 2020. The copyright holder for this preprint (which

was not certified by peer review) is the author/funder, who has granted bioRxiv a license to display the preprint in perpetuity. It is made available under aCC-BY-NC-ND 4.0 International license.

\title{
5' UTR variants in the quantitative trait gene Hnrnph1 support reduced 5' UTR usage and hnRNP H protein as a molecular mechanism underlying reduced methamphetamine sensitivity
}

Running title: Functional variants within the 5' UTR of Hnrnph1

Qiu T. Ruan ${ }^{1,2,3}$, Neema Yazdani ${ }^{1,2,3}$,Eric R. Reed ${ }^{4}$, Jacob A. Beierle ${ }^{1,2,3}$, Lucy P. Peterson ${ }^{2}$, Kimberly P. Luttik $^{1}$, Karen K. Szumlinski ${ }^{5}$, William E. Johnson ${ }^{6}$, Peter E. A. Ash ${ }^{7}$, Benjamin Wolozin ${ }^{7}$, Camron D. Bryant $^{1,2,3 *}$

1. Laboratory of Addiction Genetics, Department of Pharmacology and Experimental Therapeutics and Psychiatry, Boston University School of Medicine, 02118

2. Biomolecular Pharmacology Training Program, Department of Pharmacology and Experimental Therapeutics, Boston University School of Medicine, 02118

3. Transformative Training Program in Addiction Science, Boston University School of Medicine, 02118

4. Ph.D. Program in Bioinformatics, Boston University, 02118

5. Department of Psychological and Brain Sciences, Molecular, Cellular and Developmental Biology, Neuroscience Research Institute, University of California, Santa Barbara, 93106-9660

6. Department of Medicine, Computational Biomedicine, Boston University School of Medicine, 02118

7. Laboratory of Neurodegeneration, Department of Pharmacology and Experimental Therapeutics and Neurology, Boston University School of Medicine, 02118

\section{*Corresponding Author}

Camron D. Bryant, Ph.D.

Department of Pharmacology and Experimental Therapeutics and Department of Psychiatry

Boston University School of Medicine

72 E. Concord St. L-616

Boston, MA 02118 USA

E: camron@bu.edu

P: (617) 358-9581 
bioRxiv preprint doi: https://doi.org/10.1101/2020.01.11.902908; this version posted April 16, 2020. The copyright holder for this preprint (which

was not certified by peer review) is the author/funder, who has granted bioRxiv a license to display the preprint in perpetuity. It is made available under aCC-BY-NC-ND 4.0 International license.

\section{NONSTANDARD ABBREVIATIONS}

psychostimulant use disorder (PUD)

methamphetamine (MA)

quantitative trait locus (QTL)

substance use disorders (SUD)

DBA/2J (D2J)

C57BL/6J (B6J)

Hnrnphl mutants $\left(\mathrm{H}^{+/}\right)$

quantitative trait variant (QTV)

real-time quantitative PCR (qPCR) 


\begin{abstract}
We previously identified a $210 \mathrm{~kb}$ region on chromosome 11 (50.37-50.58 Mb, mm10) containing two protein-coding genes (Hnrnphl, Rufyl) that was necessary for reduced methamphetamine-induced locomotor activity in C57BL/6J congenic mice harboring DBA/2J polymorphisms. Gene editing of a small deletion in the first coding exon supported Hnrnphl as a quantitative trait gene. We have since shown that Hnrnphl mutants also exhibit reduced methamphetamine-induced reward, reinforcement, and dopamine release. However, the quantitative trait variants (QTVs) that modulate Hnrnphl function at the molecular level are not known. Nine single nucleotide polymorphisms and seven indels distinguish C57BL/6J from DBA/2J within Hnrnph1, including four variants within the 5' untranslated region (UTR). Here, we show that a $114 \mathrm{~kb}$ introgressed region containing Hnrnphl and Rufyl was sufficient to cause a decrease in MA-induced locomotor activity. Gene-level transcriptome analysis of striatal tissue from $114 \mathrm{~kb}$ congenics versus Hnrnphl mutants identified a nearly perfect correlation of fold-change in expression for those differentially expressed genes that were common to both mouse lines, indicating functionally similar effects on the transcriptome and behavior. Exonlevel analysis (including noncoding exons) revealed decreased 5' UTR usage of Hnrnphl and immunoblot analysis identified a corresponding decrease in hnRNP H protein in $114 \mathrm{~kb}$ congenic mice. Molecular cloning of the Hnrnph1 5' UTR containing all four variants (but none of them individually) upstream of a reporter induced a decrease in reporter signal in both HEK293 and N2a cells, thus identifying a set of QTVs underlying molecular regulation of Hnrnph1.
\end{abstract}

\title{
KEY WORDS
}

RNA binding protein, psychostimulant, functional variants, positional cloning, alternative splicing, untranslated regions 


\section{INTRODUCTION}

Psychostimulant use disorders (PUDs), including methamphetamine (MA) and cocaine dependence, are a serious public health concern in the United States. While the opioid epidemic crisis continues to garner warranted attention, there has been much less focus on the recent steep surge in PUDs as evidenced by the steep increase in PUD-related deaths, especially MA-related deaths (1). This public health concern is particularly problematic, given that there are no FDA-approved treatments for PUDs. Both genetic and environmental factors contribute to PUDs (2), yet genome-wide association studies to date have identified very few genetic factors (3). One notable example was the identification of a genome-wide association between FAM53B and cocaine dependence in humans (4). This finding was particularly interesting in the context of a mouse forward genetic study of psychostimulant addiction traits that identified a trans-expression quantitative trait locus (QTL) originating from a locus containing Cyfip2 and Hnrnph1 that influenced Fam53b expression and was associated with cocaine intravenous self-administration (5). This is one of the first examples demonstrating a direct correspondence between genome-wide genetic association, functional changes in gene expression, and trait-relevant behaviors (cocaine self-administration) between rodents and humans. Thus, this example highlights the power and translational relevance of systems genetics in mice in the study of substance use disorder (SUD)-relevant traits.

There are several advantages to using rodent forward genetics in studying the genetic basis of molecular and behavioral traits relevant to SUDs, including the ability to control allelic frequency, genetic background, the environment, the amount and length of drug exposure, the sample size, the collection of the appropriate tissue at the appropriate time points, and the ability to both map and validate causal functional variants in vivo within the same animal species. While there are clear limitations to modeling the genetic basis of psychiatric disease traits in rodents, it is important to point out studies in which there have been promising successes. In addition to the translational link of Fam53b with cocaine addiction traits in mice and humans $(4,5)$, there are multiple other recent examples of forward genetic discoveries in rodents that have yielded a high likelihood for translation to humans. A missense SNP in Taarl (trace amine-associated receptor 1) was mapped in mice for the aversive properties of MA self-administration, body temperature (6) and toxicity (7-9) and genetic variants in TAARl in humans were associated with drug craving in methamphetamine dependence (10, 11). CNIH3 (Cornichon Family AMPA Receptor Auxiliary Protein 3) was identified as a GWAS hit for opioid dependence in humans that was corroborated with a forward genetic study of morphine physical dependence in mice (12). Whole genome sequencing plus QTL analysis and functional validation identified Grm2 (mGlu2 receptor) in escalation of alcohol consumption in rats (13). A mouse strain survey correlating gene expression with behavior found a link between glyoxylase 1 (Glol) and anxiety-like behavior that was confirmed via viral knockdown and overexpression (14). A cis-eQTL and copy number variant containing Glol was subsequently discovered to segregate in outbred mice and is fixed in several classical inbred strains, thus revealing a genetic and molecular mechanism linking Glol expression with anxiety-like behavior (15). Glol metabolizes methylglyoxal which, in 
light of mouse preclinical studies, was found to act as an agonist for the GABA-A receptor and exert anxiolyticlike effects $(16,17)$. Increasing methylglyoxal levels preclinically reduced alcohol drinking $(18,19)$, induced a rapid antidepressant-like response (20), and reduced seizures (21). To summarize, mouse forward genetic studies have led to the identification and/or corroboration of several promising therapeutic targets for SUDs and other psychiatric disorders.

A major focus of our lab is to use discovery-based forward genetics to identify novel genetic factors underlying heritable differences in sensitivity to the locomotor stimulant response to drugs of abuse, including opioids as well as psychostimulants such as MA. The neurocircuitry and neurochemical mechanisms underlying drug-induced locomotor activity are in part shared with those that mediate the addictive properties of drugs of abuse (22-24); thus, a reasonable hypothesis is that a subset of shared, polymorphic genetic factors influence both sets of complex behavioral traits. Examples from our lab that support this hypothesis include casein kinase 1-epsilon (Csnk1e) which influences opioid- and MA-induced locomotor activity $(25,26)$ and opioid conditioned place preference (27) as well as heterogeneous nuclear ribonucleoprotein H1(Hnrnphl) which we first mapped and validated for MA-induced locomotor activity (28) and subsequently found influences MAinduced dopamine release in the nucleus accumbens, MA-induced reward, and MA-induced reinforcement (29).

With regard to Hnrnph1, QTL mapping in an F2 cross first identified a locus containing Hnrnph1 on chromosome 11 whereby the DBA/2J (D2J) allele was associated with reduced MA-induced locomotor activity (30). An interval-specific congenic approach was employed in C57BL/6J (B6J) mice carrying various introgressed regions on chromosome 11 from the DBA/2J strain (31) to fine map the QTL. We detected a fortuitous recombination event that revealed a $210 \mathrm{~kb}$ region on chromosome $11(50.37-50.58 \mathrm{Mb})$ that was necessary for reduced sensitivity in the locomotor stimulant response to MA (28). Replacement of this polymorphic region with the background C57BL/6J allele completely eliminated the MA-induced behavioral phenotype, thus demonstrating that this region was necessary for reduced MA-induced locomotor activity (28). The $210 \mathrm{~kb}$ region contains two protein-coding genes - Hnrnphl and Rufyl. Introduction of a heterozygous deletion within the first coding exon of each gene provided strong support for Hnrnphl (and not Rufyl) as a quantitative trait gene (QTG) underlying reduced MA sensitivity (28) and we subsequently expanded the phenotypic repertoire of the Hnrnph1 mutants to include a reduction MA reinforcement, MA reward and MAinduced dopamine release (32).

Although the combined published evidence supports Hnrnphl as a QTG for MA sensitivity, to date, we have only demonstrated that inheritance of the $210 \mathrm{~kb}$ region polymorphic region containing Hnrnphl and Rufyl is necessary for the reduction in MA-induced behavior. In order to demonstrate that this region is also sufficient, in the present study, we backcrossed and screened for congenic mice capturing only Hnrnphl and Rufy 1 and we identified a founder containing a $114 \mathrm{~kb}$ introgressed region. Following the observation of reduced MA-induced locomotor activity in $114 \mathrm{~kb}$ congenic mice, we assessed the striatal transcriptome at both 
the gene- and exon-level and compared these results to the transcriptome of Hnrnphl mutants $\left(\mathbf{H 1} \mathbf{1}^{+/}\right)$in order to provide further support for Hnrnphl as a QTG and to identify the quantitative trait variant(s) (QTV)s. Upon discovering decreased usage of the 5' UTR in Hnrnphl in $114 \mathrm{~kb}$ congenic mice as a potential molecular mechanism underlying the QTL and QTG, we validated decreased 5' UTR expression via real-time quantitative PCR (qPCR) by targeting the adjacent exon junction and the specific 5' UTR noncoding exon. We then identified decreased protein expression of hnRNP $\mathrm{H}$ in $114 \mathrm{~kb}$ congenic mice as a potential downstream functional consequence of reduced 5' UTR usage. Finally, to validate candidate QTV(s), we cloned the 5' untranslated region (5' UTR) of Hnrnphl containing either the individual Hnrnphl 5' UTR variants, or the combined set of all four 5' UTR variants fused to a luciferase reporter gene and tested the effect on reporter expression in two different cell lines. The results identify a set of 5' UTR variants within Hnrnphl that likely represent the QTVs underlying molecular regulation of Hnrnphl and behavior.

\section{MATERIALS AND METHODS}

\section{Generation of B6J.D2J $114 \mathrm{~kb}$ congenic mice}

All procedures involving mice were conducted in accordance with the Guidelines for Ethical Conduct in the Care and Use of Animals and were approved by the Institutional Animal Care and Use Committee at Boston University (\#AN-15326). The founder $114 \mathrm{~kb}$ congenic mouse was identified by monitoring the distal single nucleotide polymorphism (SNP) sites of offspring generated via backcrossing heterozygous congenic mice from Line 4a carrying one copy of a $\sim 11 \mathrm{Mb}$ introgressed interval from the D2J strain to the background B6J strain (28). We monitored for retention of the most proximal D2J SNP that was just upstream of Hnrnph1 (rs29383600; 50,373,006 bp; mm10) and this SNP defined the proximal end of the $114 \mathrm{~kb}$ interval. We previously genotyped several purported SNP markers proximal to rs29833600 that were monomorphic until 49,873,463 bp (mm10), which was catalogued by Sanger as a B6J/D2J polymorphic marker and that we genotyped as homozygous for B6J (28). Because we were unable to identify any polymorphisms between 49,873,463 bp (mm10) and rs29383600, we defined the proximal interval of this smaller congenic with the marker rs29383600 (50,373,006 bp). The remainder of the genome is isogenic for B6J as determined by several other markers on chromosome 11 and by a medium-density genotyping array containing 882 informative SNP markers from our previous study (28).

We also simultaneously monitored for the detection of a recombination event (i.e., the observation of a homozygous B6J genotype) at a second marker located just distal to Rufyl (rs254771403; 50,486,998 bp; mm10). Following detection of a recombination event at rs254771403, we then genotyped at an additional upstream proximal marker at rs29459915 (50,484,260 bp; mm10) that was also downstream of Rufyl and found retention of the D2J allele at this locus. Thus, the new remarkably smaller congenic interval was conservatively 
defined by a region spanning proximal rs29383600 (50,373,006 bp) and distal rs254771403 (50,486,498 bp), yielding a $114 \mathrm{~kb}$ interval. Thus, we named this new congenic, “114 kb”.

PCR primers were designed to amplify a 200 bp amplicon that contained and flanked each SNP. The PCR products were run on a $1.5 \%$ agarose gel and visualized for band specificity. Single bands were excised according to their predicted fragment size and gel-purified (Promega Wizard SV Gel and PCR Clean-Up System, Cat A9281), and prepared for Sanger sequencing (Genewiz, Cambridge, MA, USA). Mice homozygous for the $114 \mathrm{~kb}$ region (referred to as $114 \mathrm{~kb}$ ) and B6J littermates were generated via heterozygous-heterozygous $114 \mathrm{~kb}$ breeders. To avoid genetic drift, heterozygous $114 \mathrm{~kb}$ breeders were maintained by mating heterozygous male offspring with C57BL/6J females purchased from The Jackson Laboratory in Bar Harbor, ME, USA. Mice were SNP-genotyped using genomic DNA extracted from tail biopsies and two Taqman SNP markers: rs29383600 (50.37 Mb) and rs29459915 (50.48 Mb) (ThermoFisher Scientific, Waltham, MA, USA).

\section{Methamphetamine (MA)-induced locomotor activity in $114 \mathrm{~kb}$ congenic mice}

Both female and male littermates (56-100 days old at the start of the experiment), were phenotyped for MA-induced locomotor activity. Mice were housed in same-sex groups of 2 to 4 mice per cage in standard shoebox cages and housed within ventilated racks under standard housing conditions. Colony rooms were maintained on a 12:12 h light-dark cycle. The estimated sample size required to detect a significant effect (Cohen's $d=0.72)$, with $80 \%$ power $(p<0.05)$ was $n=25$ per genotype based on the previously published phenotype in the larger congenics capturing a QTL for reduced MA-induced locomotor activity (28). Mice were tested for baseline locomotor activity on Days 1 and 2 over $60 \mathrm{~min}$ and then administered MA (2 mg/kg, i.p.) on Days 3, 4, and 5 and were video-recorded for distance traveled over 60 min using Anymaze (Stoelting Co., Wood Dale, IL, USA) as previously described (28). Data are presented in six, five-min bins or as the summed distance traveled over $60 \mathrm{~min}$ for each of the five days of injections.

\section{Transcriptome analysis followed by gene set enrichment analysis}

Striatum punches were harvested bilaterally from $114 \mathrm{~kb}$ congenic mice homozygous for the congenic region $(\mathrm{n}=8)$ and B6J wild-type littermates $(\mathrm{n}=8)$ and processed for total RNA extractions (28). RNA samples were bioanalyzed (RIN > 8) and cDNA library was prepared using the Illumina TruSeq Standard mRNA LT (100 bp paired-end reads). The 16 samples were multiplexed and sequenced over three lanes on Illumina HiSeq 2500. The data is available on the NCBI GEO database under accession number GSE76929. FastQ files were aligned to the mouse mm10 reference genome using TopHat (33). HTSeq Python framework (34) was used to compute the read counts per gene followed by limma (35) to integrate counts and detect differentially expressed genes. For differential analysis, a linear model was used to compare gene expression between genotypes with "Cage" included as a covariate. Furthermore, between-technical replicate correlation was accounted for using the duplicateCorrelation(), limma function (36). An $\alpha$ level of $p<0.001$ was employed. For gene set 
enrichment analysis of the 69 differentially expressed genes that meet the significant cutoff, Enrichr $(37,38)$ as used to determine the enrichment of top Kyoto Encyclopedia of Genes and Genomes (KEGG) pathway terms and gene ontology (GO) terms.

\section{Differential exon usage analysis followed by gene set enrichment analysis}

For differential usage of exons using limma (35), reads were aligned to the Ensembl-annotated genome that contains extensive annotation of coding and non-coding exons and quantified using DEXSeq (39) with a requirement of one read count per exon bin and a minimum of at least 10 reads across all replicates. Similar to differential analysis, for each gene, a linear model was used to detect differential exon usage between genotypes with "Cage" included as a covariate and between-technical replicate correlation was accounted for using the duplicateCorrelation(), limma function (36). Differential exon usage was defined as the proportion of total normalized reads per gene that are counted within an exon bin for that gene. Statistical significance was evaluated using gene-level tests, including an F test that reflects a consensus signal across a gene and is highly powered to detect differential exon usage when more than one signal is observed across multiple exons per gene. We also report the results from a Simes multiple testing procedure that assesses all exons within a gene which is more powered to detect differential exon usage when a single strong signal is observed. An $\alpha$ level of $p$ $<0.001$ was employed for both the F-test and the Simes test. The 35 significant genes exhibiting differential exon usage between the $114 \mathrm{~kb}$ and B6J were analyzed for pathway enrichment using Enrichr $(37,38)$ for KEGG pathway enrichment analysis. A clustergram was used for visualization of the overlapping genes of the top enriched pathways.

\section{Real-time quantitative PCR (qPCR) validation}

For qPCR validation of exon usage, oligo-dT primers were used to synthesize cDNA from total RNA using the same samples that were used in RNA-seq analysis using SYBR Green (ThermoFisher Scientific, Waltham, MA, USA; Cat\# 4309155). The qPCR primers used for exon usage in Hnrnph1 are shown in Supplementary Table 1. Each sample was run in triplicate, averaged, and normalized to its own expression level using GAPDH as a housekeeping gene. Differential exon usage was reported as the fold-change in $114 \mathrm{~kb}$ congenic mice relative to B6J littermates using the $2^{-\left(\Delta \Delta C_{T}\right)}$ method (40).

\section{SDS-PAGE and Western blot}

Whole striata (left and right sides) were homogenized using a hand-held homogenizer in RIPA buffer supplemented with Halt protease and phosphatase inhibitor cocktail (Thermo Fisher Scientific, Waltham, MA, USA; Cat\# 78840) followed by sonication. $30 \mu \mathrm{g}$ of protein was heated in a $70^{\circ} \mathrm{C}$ water bath for 10 min before loading into a 4 - 20\% Criterion TGX precast Midi protein gel (Bio-Rad, Hercules, CA, USA; Cat\# 5671094) for SDS-PAGE followed by wet transfer to a nitrocellulose membrane. After the transfer, all membranes were 
stained with ponceau $\mathrm{S}$ solution $(0.1 \%$ ponceau $\mathrm{S}$ in $1 \%(\mathrm{v} / \mathrm{v})$ acetic acid) for 1 minute and quickly de-stained in water to remove non-specific staining. The membranes were then imaged and densitometry analysis for total protein per lane was quantified in ImageJ2 (41). The membrane was then blocked with 5\% milk for $1 \mathrm{~h}$ and probed with primary antibodies. hnRNP H protein expression was evaluated using three different antibodies: 1) C-term specific hnRNP H antibody (1:100,000, Bethyl, Montgomery, TX, USA; Cat \#A300-511A); 2) N-term specific hnRNP H antibody (1:20,000, Santa Cruz, Dallas, TX, USA; Cat\# sc-10042); and 3) hnRNP H1 antibody (1:10,000, Proteintech, Rosemont, IL, USA; Cat\# 14774-1-AP). The secondary used for the Bethyl and Proteintech antibodies was donkey anti-rabbit HRP (1:10,000, Jackson ImmunoResearch Laboratories, West Grove, PA; Cat\# 711-035-152) and the secondary used for the Santa Cruz one was bovine anti-goat HRP (1:10,000, Jackson ImmunoResearch Laboratories, West Grove, PA; Cat\# 805-035-180). All membranes were imaged via enhanced chemiluminescence photodetection. For quantification analysis of protein expression, total protein stains were used as loading controls in normalization for immunoblotting quantification $(42,43)$.

\section{Cell culture and transfection}

Human embryonic kidney (HEK)293T cells were grown in DMEM, high glucose with L-glutamine (Gibco, Waltham, MA, USA; Cat\# 11965-092), supplemented with 10\% fetal bovine serum (Gibco, Waltham, MA, USA; Cat\# 26140-079), and 1\% penicillin-streptomycin (Gibco, Waltham, MA, USA; Cat\# 15140-122). Mouse neuro(N)2a (N2a) neuron-like cells were grown in 1:1 ratio of DMEM, high glucose with L-glutamine (Gibco, Waltham, MA, USA; Cat\# 11965-092) to Opti-MEM (GibCO, Waltham, MA, USA; Cat\# 31985-070), supplemented with 5\% fetal bovine serum (Gibco, Waltham, MA, USA; Cat\# 26140-079), and 1\% penicillinstreptomycin (Gibco, Waltham, MA, USA; Cat\# 15140-122). Cells were split every 3 to 4 days and were grown at $37^{\circ} \mathrm{C}$ in an atmosphere of $5 \% \mathrm{CO}_{2}$.

For HEK293T, cells were seeded in 6-well plate at a density of $2.5 \times 10^{5}$ cells per well 24 hours prior to transfection and would be about $90 \%$ confluent at the time of transfection. For N2A (given they grow faster than HEK293T cells), cells were seeded in 6-well plate at a density of 2 × $10^{5}$ cells per well. A suspension of plasmids, Lipofectamine 3000 and P3000 reagents (ThermoFisher Scientific, Waltham, MA, USA; Cat\# L3000008) in Opti-MEM medium was pre-incubated at room temperature for 15 min before being added to each well of the 6-well plates. The cells were co-transfected with $1 \mu \mathrm{g}$ of the experimental firefly luciferase construct and $0.2 \mu \mathrm{g}$ internal pRL control plasmid expressing Renilla luciferase driven by the CMV promoter (Promega, Madison, WI, USA; Cat\# E2261). 24 hours after transfection, HEK293T cells were detached with $0.25 \%$ of Trypsin-EDTA (ThermoFisher Scientific, Waltham, MA, USA; Cat\# 25200056) and counted and reseeded at a density of $2.5 \times 10^{4}$ cells per well in 96-well plate. N2a cells were re-seeded at a density of $2 \times 10^{4}$ cells per well in 96-well plate. Cells were allowed to grow for approximately $48 \mathrm{~h}$ before measurement of luciferase activity as described below. 


\section{Luciferase reporter assay}

We cloned the B6J Hnrnph1 promoter sequence (Chr11: 50,375,375 to 50,378,330; mm10) starting at $2956 \mathrm{bp}$ upstream of the annotated transcription start site for Hnrnphl. This sequence was amplified from B6J genomic DNA extracted from spleen tissue using iProof High-Fidelity PCR kit (BIO-RAD, Hercules, CA, USA; Cat\# 172-5330) with the following primers containing XhoI and HindIII restriction enzyme sites in the sense and antisense primers respectively: sense (5'-GATTCTCGAGGCTCCCGTGATCAGATACAG-3') and anti-sense (5'-GTAAAGCTTCGTCCCTTCGGTGGTCCTGGC- 3'). The sequence was subsequently cloned into the multiple cloning site of pGL4.17[luc2/Neo] (Promega, Madison, WI, USA; Cat\# E6721) with restriction enzymes XhoI and HindIII, placing the Hnrnphl promoter was inserted upstream of firefly luciferase luc2 coding sequence.

To identify variants within Hnrnphl between D2J and B6J mice, we used the whole genome sequence dataset $(35,36)$ and the online Sanger variant query tool (REL-1505 - GRCm38) to identify a total of 16 variants including three SNPs and one idel (insertion/deletion) located in the 5' UTR of Hnrnph1 (see Table 6). To replace B6J variants with D2J variants within the 5' UTR of Hnrnphl, we conducted site-directed mutagenesis using the B6J Hnrnph1:luc2 construct as a template (Agilent QuikChange II, Santa Clara, CA, USA; Cat\# 200521) to generate four luciferase reporter lines, each containing a single D2J variant. To introduce the three SNPs and the single indel all together into the 5' UTR of Hnrnph1, multi-site directed mutagenesis was performed by using the GA7546G:luc2 construct with rs221962608 SNP variant as the template (Agilent, Santa Clara, CA, USA; Cat\# 200514). The mutagenic primers are provided in Supplemental Table 2.

To account for background fluorescence signal, untransfected cells were used to subtract out background signal from the 96-well plate. Negative control cells were transfected with the promoter-less plasmid pGL4.17[luc2/Neo]. The Dual-Glo luciferase assay system (Promega, Madison, WI, USA; Cat\# E2920) was used to measure luciferase activity. The growth medium was removed first and cells were then washed with PBS. Cell lysates were prepared by adding $50 \mu \mathrm{l}$ of $1 \mathrm{X}$ passive lysis buffer to each well to lyse the cells by shaking the plate on rocker for $15 \mathrm{~min} .20 \mu \mathrm{l}$ of lysate from each well was transferred to wells of white opaque 96-well microplate (Corning, Corning, NY, USA; Cat\# 3610). Dual-Glo LARII reagents (100 $\mu$ l) were added into each well and the firefly luminescence was measured with SpectraMax i3x microplate reader after 15 min. An equal amount $(100 \mu \mathrm{l})$ of Stop \& Glo reagent was then added to the wells and Renilla luminescence was measured after $15 \mathrm{~min}$.

Firefly and Renilla luciferase signal values were subtracted from the average background signal first. The background-adjusted firefly luciferase activity (FLA) for each sample was normalized to the backgroundadjusted internal control Renilla luciferase activity (RLA) to correct for differences in transfection efficiency 
and cell death. Relative luciferase activity for each experimental construct is expressed as the fold increase over the B6J Hnrnph1:luc2 control:

$$
\text { Normalized luciferase activity }=\frac{\left(\frac{F L A}{R L A}\right)_{\text {Experimental }}}{\left(\frac{F L A}{R L A}\right)_{\text {B6J Hnrnph1:luc2 control }}}
$$

\section{Experimental design and statistical analyses}

All data are presented as means of replicates from each experiment \pm S.E.M. For experiments in which two conditions were compared, a two-tailed unpaired t-test was used to analyze the data unless otherwise specified. For the behavioral experiments in which multiple factors were evaluated, ANOVA was used and significant interactions were deconstructed along the relevant factor to examine main effects and group differences followed up with t-tests. For the qPCR validation and luciferase report assay analyses in which multiple factors were evaluated, ANOVA was used and significant interactions were deconstructed with Dunnett's post hoc test for multiple comparisons. Statistical $\alpha$ level for t-test, ANOVA, and post-hoc tests were set to 0.05 . The data comprising MA-induced locomotor activity were analyzed in R (http://www.Rproject.org/). All other data analyses were performed in GraphPad Prism (Version 8.3.0).

\section{RESULTS}

\section{Positional cloning of a $114 \mathrm{~kb}$ interval that is necessary for reduced MA sensitivity}

In backcrossing the congenic line "Line 4a" that captured a QTL for reduced MA-induced locomotor activity and contained a heterozygous introgressed region from the $\mathrm{D} 2 \mathrm{~J}$ strain that spanned $50 \mathrm{Mb}$ to $60 \mathrm{Mb}$, we monitored for recombination events at rs254771403 (50,486,998 bp, mm10). We identified a crossover event that defined $114 \mathrm{~kb}$ congenic region that influenced MA sensitivity. There are two protein coding genes within this 114 kb region - Hnrnphl and Rufyl (Fig.1A). 114 kb congenic mice homozygous for the D2J allele within this region on an otherwise isogenic B6J background displayed no difference in saline-induced locomotor activity, compared to their wild-type homozygous B6J littermates (Fig.1B,C). In response to an acute dose of MA on Day 3, 114 kb congenic mice showed reduced locomotor activity relative to B6J (Fig.1D). Again, in response to a second dose of MA on Day 4, the $114 \mathrm{~kb}$ congenic mice showed reduced MA-induced locomotor activity compared to B6J wild-type littermates (Fig.1E). No genotypic difference in MA-induced locomotor activity were observed on Day 5 after the third MA injection (Fig.1F) which is potentially explained by a ceiling effect on sensitization at this dose.

In examining changes in summed locomotor activity across days, both $114 \mathrm{~kb}$ and B6J mice showed habituation to the testing apparatus as indicated by a reduction in saline-induced locomotor activity from Day 1 to Day 2 (Fig.1G). $114 \mathrm{~kb}$ congenic mice showed greater sensitization to repeated doses of MA from Day 3 to 
Day 5 (Fig.1G), due to their initially lower level of acute-MA-induced locomotor activity on Day 3 compared to B6J wild-types. In comparing summed locomotor activity over $60 \mathrm{~min}$ across the five days, the $114 \mathrm{~kb}$ congenic mice showed a significant reduction in MA-induced locomotor activity compared to B6J wild-type littermates on Day 4 (Fig.1G). Taken together, these results indicate that $114 \mathrm{~kb}$ congenic mice are less sensitive to the locomotor stimulant response to MA.

\section{Normalized, acute MA-induced locomotor activity and locomotor sensitization in 114 kb congenic mice}

Next, we examined MA-induced locomotor activity while accounting for individual differences in baseline locomotion in response to saline on Day 2 (Fig.2A-C), as well as MA-induced locomotor sensitization (Fig.2D-F), via differences in MA-induced locomotor activity between MA treatment days. When accounting for non-drug locomotor activity, we again found that $114 \mathrm{~kb}$ congenic mice showed less acute MA-induced locomotor activity relative to B6J mice (Fig.2A), as well as after repeated exposure to MA (Fig.2B-C). After two MA injections (comparing Day 4 versus Day 3 activity), 114 kb congenic mice showed a significant decrease in locomotor sensitization early post-injection (Fig.2D). After three MA injections (comparing between Day 5 and Day 3), 114 kb congenic mice showed a significant increase in locomotor sensitization, starting at 20 min post-MA (Fig.2E). Again, when comparing Day 5 versus Day 4, 114 kb congenic mice also showed significantly greater MA locomotor sensitization relative to B6J mice (Fig.2F). The more delayed, greater sensitization in $114 \mathrm{~kb}$ congenic mice during the later MA injections is likely due to their initially lower MA response which takes longer to sensitize.

\section{Transcriptome analysis of the striatum identifies differential usage of the Hnrnph1 5' UTR in $114 \mathrm{~kb}$ congenic mice}

To further understand the molecular mechanism of the $114 \mathrm{~kb}$ congenic region in reducing MA sensitivity, we performed both differential gene expression and differential exon usage analysis on RNA-seq data collected from the striatum of naïve $114 \mathrm{~kb}$ and their B6J wild-type littermates. We identified 69 differentially expressed genes ( $p<0.001$; Table 1). Enrichr analysis of these 69 genes for pathway and gene ontology (GO) terms identified enrichment for several terms potentially related to MA-induced dopamine release and behavior, including circadian entrainment, cholinergic synapse, cAMP signaling pathway, long-term potentiation, and regulation of synaptic transmission (Table 2).

Exon-level analysis of coding and noncoding exons (e.g., 5' UTR noncoding exons) identified 35 genes exhibiting differential exon usage (Table 3A,B), which is defined as the proportion of total normalized reads per gene that are counted within an exon bin for that gene. Enrichr analysis of the 35 genes for pathway analysis identified an enrichment of dopaminergic synapse and amphetamine addiction involving Ppp3ca, Calm2 and Mapk2 as well as calcium signaling and long-term potentiation involving Ppp3ca and Calm2 (Fig.3). Notably, Hnrnphl (the first protein-coding gene within the $114 \mathrm{~kb}$ congenic interval) was one of the top genes exhibiting 
differential exon usage (Table 3A), providing direct evidence at the exon level that one or more functional variants within Hnrnphl regulates exon usage and ultimately underlies differences in MA behavior. Note that Hnrnphl did not show a significant difference in overall gene-level transcript levels $\left(\log _{2} \mathrm{FC}=0.016\right.$; $\mathrm{t}(14)=$ $0.70 ; \mathrm{p}=0.49$; adjusted $\mathrm{p}=0.99$ ). Thus, any subsequent downstream functional changes that we report are not mediated by overall Hnrnphl transcript levels, but instead, by transcripts with alternative exons (either coding or noncoding; see Table 5). It should also be noted that we did not identify a significant difference in gene expression or in exon usage of Rufyl (the second protein-coding gene within the interval), thus limiting functional effects of D2J variants at the mRNA level to Hnrnphl and further supporting the candidacy of Hnrnphl as a quantitative trait gene underlying MA behavior (28).

We previously showed that mice heterozygous for a 16-bp deletion within the first coding exon of Hnrnphl (refer to as the $\mathrm{H}^{+/-}$mice) were less sensitive to the stimulant, rewarding, and reinforcing properties of MA and showed a reduction in MA-induced dopamine release $(28,32)$. To directly compare the functional effects of inheriting the deletion versus the $114 \mathrm{~kb}$ congenic region on gene expression and exon usage, we identified 21 overlapping genes that were differentially expressed in the striatum between $114 \mathrm{~kb}$ congenic mice and $\mathrm{H}^{+/-}$mice relative to their B6J wild-type littermates (Fig.4A), which was significantly greater than what would be expected by chance (Fisher's exact test: $p=9.31 \mathrm{E}-23$ ). In addition, there were 10 overlapping genes between $\mathrm{H}^{+/-}$and $114 \mathrm{~kb}$ congenic mice that showed differential exon usage, relative to their B6J littermates (Fig.4B). Again, this overlap was significantly greater than what would be expected by chance (Fisher's exact test: $p=2.96 E-07)$. Finally, in correlating differential expression for the 21 shared differentially expressed genes between $114 \mathrm{~kb}$ congenic mice and $\mathrm{H} 1^{+/-}$mice, we found a nearly perfect relationship between the magnitude and direction of change in gene expression (Table 4 and Fig.5). These results suggest functionally similar effects of the $114 \mathrm{~kb}$ region and the $\mathrm{H}^{+/-}$allele on their overlapping, convergent transcriptome.

The physical positions and exon numbers comprising differential exon usage of Hnrnphl in $114 \mathrm{~kb}$ relative to B6J mice are shown in Table 5. Note that fewer normalized reads were mapped to the junction comprising exon 3 and exon 4 in $114 \mathrm{~kb}$ congenic mice versus B6J $\left(\log _{2} \mathrm{FC}=-0.484=1.4\right.$-fold decrease; Table 5). Additionally, a greater number of normalized reads mapped to the junction comprising exons 6 and 7 , as well as the junction comprising exons 7 and 8 in the $114 \mathrm{~kb}$ congenic mice relative to B6J (Table 5). It is important to note that Hnrnph2 (homolog of Hnrnph1) did not show differential exon usage in our analysis (F = 1.330, Fstat $p=0.198$, Fstat FDR $=1$ and Simes $p=0.38$, Simes FDR $=0.998$ ). To validate differential exon usage of Hnrnphl, we performed qPCR with primers flanking those exons exhibiting significant differential exon usage. Out of the three exon junctions, $114 \mathrm{~kb}$ congenic mice showed less usage of exons 3 to 4 , but no difference in the other two exon junctions (Fig.6A). To further validate the specific exons exhibiting differential usage, we designed primers to target exon 3 (5' UTR noncoding exon) and exon 4 (first coding exon) separately. Less usage of the 5' UTR noncoding exon was detected in the $114 \mathrm{~kb}$ congenic mice (Fig.6B), with no change in the first coding exon (Fig.6C). Exons 1 to 3 are noncoding exons that comprise the 5' UTR of 
Hnrnph1 (see Fig.8). Thus, we conclude that $114 \mathrm{~kb}$ congenic mice show a reduced number of Hnrnphl transcripts that include this 5' UTR exon.

\section{Reduced hnRNP H protein expression in the striatum of $114 \mathrm{~kb}$ congenic mice}

Three different antibodies for detecting and quantifying hnRNP H protein expression between $114 \mathrm{~kb}$ congenic mice and B6J wildtype litters were used and all samples analyzed are shown in Fig.7A. A significant decrease in hnRNP H immunoreactivity was detected with all three antibodies in the $114 \mathrm{~kb}$ congenic mice as indicated by total protein stain normalized densitometry values (Supplemental Fig.1) that were in turn normalized to averaged B6J values to illustrate fold-change ( $\mathrm{p}=0.003,0.014,0.01$; Fig.7B-D). Thus, Hnrnph1 variants in $114 \mathrm{~kb}$ congenic mice are associated with both a decrease in Hnrnphl 5' UTR usage and decrease in hnRNP H protein expression.

\section{Identification of a set of 5' UTR functional variants in Hnrnph1 that decrease translation using a} luciferase reporter assay

Three SNPs and one indel between D2J and B6J are located within the 5' UTR noncoding exons and introns (Fig.8 and Table 6). Given that the 5' UTR contains a promoter element for translational regulation, we employed a luciferase reporter system to assay the strength of the Hnrnphl promoter in the presence of one or all four of the 5' UTR variants in both Human Embryonic Kidney (HEK) 293T and Neuro2a (N2a) cells. We engineered a Hnrnph1:luc2 construct by cloning 2956 bp of the B6J Hnrnph1 promoter into the pGL4.17[luc2/Neo] promoter-less vector (Supplemental Fig.2 and 3A; Fig.9A). The 2956-bp promoter increased firefly luminescence compared to the pGL4.17[luc2/Neo] vector, and this increase in signal showed a cell number dependency (Supplemental Fig.3B). Using site-directed mutagenesis, we constructed 4 Hnrnphl promoters each possessing its own D2J variant within the 5' UTR (Supplemental Table 2). In HEK293T cells, none of the four promoters with a single D2J variant showed a significant difference between the wild-type B6J Hnrnph1 promoter in driving luciferase expression (Fig.9B). However, when all four D2J variants were introduced into the promoter, there was a significant reduction in luciferase activity compared to the B6J promoter ( $p=5.68 \mathrm{E}-11$; Fig.9C). The findings were subsequently replicated in N2a cells $(p=1.19 \mathrm{E}-06$; Fig.9D-E).

Taken together, these results identify a set of functional 5' UTR variants within Hnrnphl that are associated with a decrease in usage of the 5' UTR noncoding exon 3, a decrease in hnRNP H protein expression, and that reduce Hnrnph1 5' UTR driven translation.

\section{DISCUSSION}

The $114 \mathrm{~kb}$ region containing two protein genes (Hnrnph1, Rufyl) was not only necessary (28), but was also sufficient to cause a decrease in sensitivity to the locomotor stimulant response to MA (Fig.1). Our prior 
work strongly implicated Hnrnphl and not Rufyl as the QTG responsible for the reduction in MA-induced locomotor activity (28) and we subsequently expanded the behavioral repertoire of $\mathrm{H} 1^{+/-}$mice to include reduced MA-induced reinforcement, reward, and dopamine release (32). Our exon-level transcriptome analysis and comparative differential gene expression analysis between the $114 \mathrm{~kb}$ congenics and $\mathrm{H} 1^{+/}$mice further supports Hnrnphl as the QTG underlying the reduction in MA-induced behavior (Fig.4 and Table 3).

Decreased usage of the 5' UTR noncoding exon 3 of Hnrnphl in $114 \mathrm{~kb}$ congenic mice was independently validated via qPCR (Fig.6). Approximately 13\% of genes in the mammalian transcriptome show differences in 5' UTR splicing of their transcripts (44). Inheritance of the Hnnrph1 5' UTR variants (along with the other Hnrnphl variants; Table 6) were associated with a decrease in striatal hnRNP H protein expression (Fig.7). We identified a set of four variants within and flanking the 5' UTR that decreased reporter expression in two different cell lines (Fig.9), thus identifying a set of QTVs underlying molecular regulation of Hnrnphl and likely MA behavior.

Identification of QTGs and QTVs is extremely rare in mammalian forward genetic studies, in particular for behavior (45), and especially when considering the identification of noncoding functional variants. In the recent identification of a noncoding functional variant underlying a cis-expression QTL, Mulligan and colleagues took advantage of the reduced genetic complexity of closely related C57BL/6 substrains $(46,47)$ to deduce and validate an intronic variant in Gabra2 (alpha-2 subunit of the GABA-A receptor) near a splice site that drastically reduced transcript and protein expression and modulated behavior (48). Correction of the single base deletion in C57BL/6J to the wild-type C57BL/6N allele via CRISPR/Cas9-mediated gene editing restored Gabra2 transcript and protein levels to a normal level, thus identifying the QTV (48). The vast majority of other examples that successfully identified both the QTG and the QTV involve functional coding mutations, including Cyfip2 (49), Grm2 (13), and Taarl (50). With regard to Hnrnph1, a human candidate gene association study identified a functional intronic variant in OPRMI (mRNA target of hnRNP H) that affected binding to hnRNP H to regulate splicing and was associated with the severity of heroin addiction (51).

Less than one-third of genes analyzed in human cell lines showed a direct correlation between mRNA level and protein expression $(52,53)$. Furthermore, cis-expression QTL analysis at both the mRNA and protein level in Diversity Outbred mice indicated the presence of genetic variants that regulate protein levels without affecting overall transcript levels (54). In support, our gene-level transcriptome analysis did not identify Hnrnph1 as a differentially expressed gene; however, exon-level analysis identified decreased 5' UTR noncoding exon usage of Hnrnphl in 114 kb congenic mice (Fig.6; Table 5) that was associated with decreased hnRNP H protein expression (Fig.7). Genetic variants within cis-regulatory elements located in the 5' UTR and 3' UTR of genes and trans-regulatory factors that bind to these elements (e.g. RNA-binding proteins (RBPs)) can perturb translation or overall protein abundance $(52,53,55-57)$. In our study, we identified an association between decreased 5' UTR usage and decreased hnRNP H protein expression in $114 \mathrm{~kb}$ congenic mice. The GC content, secondary structure, and length of the 5' UTR can affect translational efficiency $(52,58,58)$. Thus, the 
altered GC content within the 5' UTR of Hnrnph1 in $114 \mathrm{~kb}$ congenic mice could inhibit translation by changing the thermal stability of secondary stem loop structure (52). Because the length of the 5' UTR determines the amount of energy needed for the ribosome to reach the AUG start site (55), a change in length of the 5' UTR in Hnrnphl caused by the set of $114 \mathrm{~kb}$ variants could also alter protein synthesis. Also, a change in binding sites for RBPs to regulate translation could contribute to reduced hnRNP H protein in $114 \mathrm{~kb}$ congenic mice $(59,60)$. RBPs recognizes specific motifs in the 5' UTRs, and thus, a change in the sequence of these motifs induced by these variants could alter the association of RBPs with the translation machinery at the 5' UTR of Hnnrphl to control expression. The RBPDB database (61) indicates that several RBPs are predicted to bind to the 5' UTR of Hnrnphl, though notably not hnRNP H itself (Supplementary Table 3).

The hnRNP family of RBPs act in concert to regulate RNA metabolism and gene expression of other RBPs (62). Downregulation of hnRNP H protein in $114 \mathrm{~kb}$ congenic mice (Fig.7) could affect complexing of hnRNP H with other RBPs to regulate expression and in turn, alter recruitment of RBPs involved in splicing of the 5' UTR of Hnrnphl. As an example, hnRNP A1 is predicted to bind to the 5' UTR of Hnrnphl (61) and this RBP is known to cooperate with hnRNP H in mediating gene splicing (63). Thus, although Hnrnphl is not predicted to be a direct target of hnRNP H, reduced hnRNP H protein could alter the expression of and coordination with other RBPs to regulate 5' UTR usage of Hnrnph1.

To summarize, we provide further causal behavioral and molecular evidence for Hnrnphl as a QTG for MA sensitivity by demonstrating that inheritance of a small, $114 \mathrm{~kb}$ chromosomal region was not only necessary (28) but also sufficient to induce the behavioral phenotype. We provide functional evidence for a set of four QTVs within the 5' UTR that could plausibly reduce 5' UTR usage and the amount of hnRNP H protein; however, demonstrating that these four variants are sufficient alone to induce these functional effects on Hnrnph1 molecular regulation and behavior would require the generation of a mouse model containing only these four variants. The relatively subtle effect of the $114 \mathrm{~kb}$ region on behavior raises the question of whether modeling these variants in vivo is worth the effort - convergent evidence provides strong evidence that we have identified a set of QTVs underlying functional molecular and behavioral changes. Future studies involving cell type-specific knockdown of Hnrnphl using the Cre-loxP system will efficiently and more selectively model the effects of reduced hnRNP H protein expression on MA-induced behavior.

\section{AUTHOR CONTRIBUTIONS}

Q. T. Ruan, N. Yazdani, K.K. Szumlinski, P. E. A. Ash, B. Wolozin, and C. D. Bryant designed research; Q. T. Ruan, N. Yazdani, and E. R. Reed analyzed data; Q. T. Ruan, N. Yazdani, J. A. Beierle, L. P. Peterson, and K. P. Luttik performed research; P. E. A. Ash and B. Wolozin contributed new reagents or analytical tools; Q.T. Ruan and C. D. Bryant wrote the paper. 


\section{FIGURE LEGENDS}

Figure 1. MA-induced locomotor activity in the $114 \mathrm{~kb}$ congenic mice. (A): Congenic mice containing an introgressed $114 \mathrm{~kb}$ region on chromosome 11 from the D2J strain on an isogenic B6J background were identified via backcrossing and screening for a recombination event at rs254771403 $(50,486,998$ bp; mm10) while monitoring for the retention of polymorphic rs29383600 (50,373,006 bp; mm10) and polymorphic rs29459915 (50,484,260 bp; mm10), and. Mice were then backcrossed again to B6J to generate additional heterozygotes for intercrossing (heterozygous-heterozygous breeding) which yielded heterozygous offspring as well as offspring homozygous for the $114 \mathrm{~kb}$ region (homozygous D2J) and wild-type homozygous B6J littermates. Behavioral analysis and results are shown for the homozygous genotypes. The $114 \mathrm{~kb}$ region contains two protein-coding genes: Hnrnphl and Rufyl. Mice were injected on Days 1 to 2 with saline (i.p.; panels B and C) and on Days 3, 4, and 5 with $2 \mathrm{mg} / \mathrm{kg} \mathrm{MA} \mathrm{(panels} \mathrm{D,} \mathrm{E,} \mathrm{and} \mathrm{F).} \mathrm{Locomotor} \mathrm{activity} \mathrm{was} \mathrm{video-}$ recorded for $60 \mathrm{~min}$ on each day and is presented in 5-min bins over $60 \mathrm{~min}$. (B,C): No genotypic differences were observed in distance traveled in response to a saline injection on Day 1 [mixed ANOVA: $F(1,46)_{\text {Genotype }}=$ $1.48, \mathrm{p}=0.229 ; \mathrm{F}(11,506)_{\text {Genotype } \mathrm{x} \text { Time }}=1.48, \mathrm{p}=0.133$ ] or Day $2\left[\operatorname{mixed}\right.$ ANOVA: $\mathrm{F}(1,46)_{\text {Genotype }}=0.003, \mathrm{p}=$ 0.958; $\left.\mathrm{F}(11,506)_{\text {Genotype } \mathrm{x} \text { Time }}=1,29, \mathrm{p}=0.227\right]$. A main effect of Sex was detected for both Days 1 and 2 $\left[\mathrm{F}(1,46)_{\text {Day1 }}=10.52, \mathrm{p}=0.002 ; \mathrm{F}(1,46)_{\text {Day2 }}=9.83, \mathrm{p}=0.003\right]$. However, there was no significant Genotype $\mathrm{x}$ Sex interaction for Day 1 or Day $2\left[\mathrm{~F}(1,46)_{\text {Day } 1}=0.32, \mathrm{p}=0.576 ; \mathrm{F}(1,46)_{\text {Day } 2}=2.32, \mathrm{p}=0.134\right]$. (D): Locomotor activity on Day 3 in response to MA is shown in 5-min bins over $60 \mathrm{~min} .114 \mathrm{~kb}$ congenic mice showed reduced acute MA-induced locomotor activity relative to B6J wild-type littermates [mixed ANOVA: $\mathrm{F}(1,46)_{\text {Genotype }}=3.41, \mathrm{p}=0.071 ; \mathrm{F}(11,506)_{\text {Genotype } \mathrm{x} \text { Time }}=2.80, \mathrm{p}=0.002$; unpaired $\mathrm{t}$-test for each 5-min bin: $\left.\mathrm{t}(48)_{30 \min }=2.17,{ }^{*} \mathrm{p}=0.035 ; \mathrm{t}(48)_{50 \min }=2.05,{ }^{*} \mathrm{p}=0.045\right]$. A main effect of Sex was also detected $[\mathrm{F}(1,46)=$ 4.32, $\mathrm{p}=0.043]$, however, there was no significant Genotype $x$ Sex interaction $[F(1,46)=2.74, p=0.104]$. $(E)$ : MA-induced locomotor activity on Day 4 is shown in 5-min bins over $60 \mathrm{~min} .114 \mathrm{~kb}$ congenic mice showed reduced MA-induced locomotor activity relative to B6J mice [mixed ANOVA: F $(1,46)_{\text {Genotype }}=5.40, \mathrm{p}=$ 0.025; $\mathrm{F}(11,506)_{\text {Genotype } \times \text { Time }}=1.96, \mathrm{p}=0.031 ;$ unpaired $\mathrm{t}$-test for each 5-min bin: $\mathrm{t}(48)_{15 \min }=2.43, * \mathrm{p}=0.019$; $\left.\mathrm{t}(48)_{20 \min }=3.10,{ }^{*} \mathrm{p}=0.003 ; \mathrm{t}(48)_{25 \min }=2.90,{ }^{*} \mathrm{p}=0.006 ; \mathrm{t}(48)_{30 \min }=2.22, * \mathrm{p}=0.031\right]$. A main effect of Sex was also detected $[\mathrm{F}(1,46)=7.33, \mathrm{p}=0.009]$ but no significant Genotype $x$ Sex interaction $[\mathrm{F}(1,46)=2.05, \mathrm{p}=$ 0.159]. (F): MA-induced locomotor activity is shown for Day 5 in 5-min bins over 60 min. $114 \mathrm{~kb}$ congenic mice showed no difference in MA-induced locomotor activity compared to B6J [mixed ANOVA: $\left.\mathrm{F}(11,506)_{\text {Genotype } x \text { Time }}=0.59, \mathrm{p}=0.841\right]$. A main effect of Sex was detected $[\mathrm{F}(1,46)=6.09, \mathrm{p}=0.017]$, however, there was no significant Genotype $x$ Sex interaction $[F(1,46)=0.39, p=0.535]$. (G): Locomotor activity summed over $60 \mathrm{~min}$ is shown for Days 1 and 2 (saline) and on Days 3, 4, and 5 (MA). In examining habituation via changes in locomotor activity in response to saline injections on Day 1 versus Day 2, both B6J and $114 \mathrm{~kb}$ showed similar degree of habituation [mixed ANOVA: $\mathrm{F}(1,46)_{\text {Genotype }}=0.47, \mathrm{p}=0.496 ; \mathrm{F}(1,46)_{\text {Day }}$ $=225.51, \mathrm{p}<2 \mathrm{E}-16 ; \mathrm{F}(1,46)_{\text {Genotype } x \text { Day }}=1.35, \mathrm{p}=0.252 ;$ unpaired t-test for each day: $\mathrm{t}(50)_{\text {Day } 1}=6.34,{ }^{\#} \mathrm{p}=$ 
3.26E-04; $\left.\mathrm{t}(46)_{\text {Day } 2}=6.64,{ }^{*} \mathrm{p}=1.55 \mathrm{E}-04\right]$. In examining sensitization of MA-induced locomotor activity across Day 3, Day 4, and Day 5, $114 \mathrm{~kb}$ congenic mice showed increased locomotor sensitization relative to B6J [mixed ANOVA: F $(1,46)_{\text {Genotype }}=2.74, \mathrm{p}=0.105 ; \mathrm{F}(2,92)_{\text {Day }}=65.71, \mathrm{p}<2 \mathrm{E}-16 ; \mathrm{F}(2,92)_{\text {Genotype } \mathrm{x} \text { Day }}=$ $5.03, \mathrm{p}=0.009]$. Only the $114 \mathrm{~kb}$ congenic mice showed an increase in MA-induced locomotor activity across the three MA treatment days [Bonferroni's multiple comparison tests (adjusted for 3 comparisons in $114 \mathrm{~kb}$ congenics and B6J group separately): Day 3 versus D4: $\mathrm{t}(50)_{\mathrm{B} 6 \mathrm{~J}}=2.40, \mathrm{p}=0.120 ; \mathrm{t}(46)_{114 \mathrm{~kb}}=2.76,{ }^{*} \mathrm{p}=0.050$; Day 3 versus D5: $\mathrm{t}(50)_{\mathrm{B} 6 \mathrm{~J}}=2.45, \mathrm{p}=0.108 ; \mathrm{t}(46)_{114 \mathrm{~kb}}=4.52,{ }^{*} \mathrm{p}=2.57 \mathrm{E}-04$; Day 4 versus D5: $\mathrm{t}(50)_{\mathrm{B} 6 \mathrm{~J}}=0.12$, $\left.\mathrm{p}=0.999 ; \mathrm{t}(46)_{114 \mathrm{~kb}}=1.92, \mathrm{p}=0.368\right]$. In addition, $114 \mathrm{~kb}$ congenic mice showed reduced MA-induced locomotor activity compared to B6J mice on Day 4 when compared across all five days [mixed ANOVA: $\mathrm{F}(4,184)_{\text {Genotype } x \text { Day }}=3.96, \mathrm{p}=0.004$; unpaired t-test for each day: $\left.\mathrm{t}(48)_{\text {Day } 4}=2.16,{ }^{\%} \mathrm{p}=0.036\right]$. A main effect of Sex was detected $[F(1,46)=9.17, p=0.004]$ but there was no significant Genotype $x$ Sex interaction $[F(1,46)=2.14, p=0.150]$. Data are represented as the mean \pm S.E.M.

\section{Figure 2. Normalized MA-induced locomotor activity and locomotor sensitization in 114 kb congenic}

mice. Mice were injected (i.p.) with saline on Days 1 to 2 and with $2 \mathrm{mg} / \mathrm{kg}$ MA on Days 3, 4, and 5.

Locomotor activity was recorded for $60 \mathrm{~min}$. (A): Day 3 - Day 2 distance traveled represents the acute locomotor response to MA while accounting for individual differences in non-drug, saline-induced locomotor activity. $114 \mathrm{~kb}$ congenic mice showed less acute MA-induced locomotor activity relative to B6J wild-type littermates [mixed ANOVA: $\mathrm{F}(1,46)_{\text {Genotype }}=3.43, \mathrm{p}=0.070 ; \mathrm{F}(11,506)_{\text {Genotype } \times \text { Time }}=2.36, \mathrm{p}=0.008$; unpaired $\mathrm{t}$-test for each 5-min bin: $\left.\mathrm{t}(48)_{25 \min }=2.30,{ }^{*} \mathrm{p}=0.033 ; \mathrm{t}(48)_{30 \min }=2.18,{ }^{*} \mathrm{p}=0.035\right]$. (B): Day $4-$ Day 2 distance traveled represents the locomotor response to the second, repeated dose of MA while accounting for individual differences in non-drug, saline-induced locomotor activity. $114 \mathrm{~kb}$ congenic mice showed less MAinduced locomotor activity relative to B6J [mixed ANOVA: $\mathrm{F}(1,46)_{\text {Genotype }}=5.25, \mathrm{p}=0.027 ; \mathrm{F}(11,506)_{\text {Genotype } \mathrm{x}}$ Time $=1.76, \mathrm{p}=0.058$; unpaired t-test for each 5-min bin: $\mathrm{t}(48)_{10 \min }=2.15,{ }^{*} \mathrm{p}=0.037 ; \mathrm{t}(48)_{15 \min }=2.47,{ }^{*} \mathrm{p}=$ $\left.0.017 ; \mathrm{t}(48)_{20 \min }=2.80, * \mathrm{p}=0.007 ; \mathrm{t}(48)_{25 \min }=3.34, * \mathrm{p}=0.002 ; \mathrm{t}(48)_{30 \min }=2.24, * \mathrm{p}=0.030\right]$. (C): Day $5-$ Day 2 distance traveled represents locomotor response to the third, repeated dose of MA while accounting for individual differences in saline locomotor activity. No genotypic difference in locomotor activity was observed in response to the third dose of MA [mixed ANOVA: $\mathrm{F}(1,46)_{\text {Genotype }}=0.17, \mathrm{p}=0.680 ; \mathrm{F}(11,506)_{\text {Genotype } \mathrm{x} \text { Time }}=$ 0.92, $\mathrm{p}=0.523$ ]. (D): Day 4 - Day 3 distance traveled is shown to represent locomotor sensitization from the first to the second MA injection. $114 \mathrm{~kb}$ congenic mice showed a decrease in locomotor sensitization during the first 15 min [mixed ANOVA: $\mathrm{F}(1,46)_{\text {Genotype }}=0.47, \mathrm{p}=0.495 ; \mathrm{F}(11,506)_{\text {Genotype } \mathrm{x} \text { Time }}=3.09, \mathrm{p}=4.92 \mathrm{e}-5$; unpaired t-test for each 5-min bin: $\left.\mathrm{t}(48)_{5 \min }=2.47{ }^{*} \mathrm{p}=0.017 ; \mathrm{t}(48)_{15 \min }=2.47,{ }^{*} \mathrm{p}=0.017\right]$. (E): Day $5-$ Day 3 distance traveled is shown to indicate the degree of sensitization observed following the third MA injection relative to the first MA exposure. $114 \mathrm{~kb}$ congenic mice showed an increase in locomotor sensitization relative to B6J [mixed ANOVA: $\mathrm{F}(1,46)_{\text {Genotype }}=5.35, \mathrm{p}=0.025 ; \mathrm{F}(11,506)_{\text {Genotype } \mathrm{x} \text { Time }}=1.95, \mathrm{p}=0.032$; unpaired $\mathrm{t}$ test for each 5-min bin: $\mathrm{t}(48)_{20 \min }=2.30, \mathrm{p}=* 0.026 ; \mathrm{t}(48)_{25 \min }=2.07, * \mathrm{p}=0.044 ; \mathrm{t}(48)_{30 \min }=2.11, * \mathrm{p}=0.040$; 
$\left.\mathrm{t}(48)_{45 \min }=2.27,{ }^{*} \mathrm{p}=0.028 ; \mathrm{t}(48)_{50 \min }=2.80, \mathrm{p}=0.007\right] .(\mathbf{F}): \mathrm{D} 5-\mathrm{D} 4$ distance traveled is shown to indicate which genotype continued to sensitize from the second MA injection to the third MA injection. Again, $114 \mathrm{~kb}$ congenic mice showed increased locomotor sensitization relative to B6J [mixed ANOVA: $\mathrm{F}(1,46)_{\text {Genotype }}=8.50$, $\mathrm{p}=0.006 ; \mathrm{F}(11,506)_{\text {Genotype } \mathrm{x} \text { Time }}=1.75, \mathrm{p}=0.061 ;$ unpaired t-test for each 5-min bin: $\mathrm{t}(48) 5 \mathrm{~min}=2.67,{ }^{*} \mathrm{p}=$ $0.010 ; \mathrm{t}(48) 15 \mathrm{~min}=3.28,{ }^{*} \mathrm{p}=0.002 ; \mathrm{t}(48) 20 \mathrm{~min}=4.59,{ }^{*} \mathrm{p}=3.17 \mathrm{E}-05 ; \mathrm{t}(48) 25 \mathrm{~min}=3.43,{ }^{*} \mathrm{p}=0.001$; $\mathrm{t}(48) 35 \mathrm{~min}=2.24, * \mathrm{p}=0.030]$. No main effect of Sex was detected for any locomotor sensitization measures (panels A-F) $\left[\mathrm{F}(1,46)_{\mathrm{Sex}}<0.8\right.$, all p's $\left.>0.3\right]$. Data are represented as the mean \pm S.E.M.

Figure 3. Pathway analysis of the top genes with differential exon usage. We identified 35 genes showing differential exon usage between $114 \mathrm{~kb}$ and B6J mice ( $\mathrm{p}$ 0.001). The top 10 enriched KEGG pathways along with the five genes overlapping with each of these pathways are shown in the clustergram. The enriched pathways are shown in columns and input genes are shown in the rows and cells (in orange) in the matrix to indicate if a gene is associated with a pathway.

Figure 4. Overlap in differentially expressed genes and genes exhibiting differential exon usage between $114 \mathrm{~kb}$ congenic mice and $\mathrm{H1}^{+/-}$mice. (A): Venn diagram showing the number of differentially expressed genes (DEGs) in $114 \mathrm{~kb}(\mathrm{p}<0.001)$ versus $\mathrm{H} 1^{+/-}$mice $(\mathrm{p}<0.001)$. The 21 DEGs that were shared between the two are significantly greater than what would be expected by chance (Fisher's exact test: $\mathrm{p}=9.31 \mathrm{E}-23$ ) as it represents nearly $1 / 2$ of the 48 total DEGs identified in $114 \mathrm{~kb}$ congenic mice. (B): Venn diagram shows the number of non-overlapping and overlapping genes with differential exon usage in $114 \mathrm{~kb}$ congenic mice $(\mathrm{p}<$ $0.001)$ versus $\mathrm{H}^{+/-}$mice $(\mathrm{p}<0.001)$. Ten genes showed differential exon usage in both the $114 \mathrm{~kb}$ congenic mice and the $\mathrm{H}^{+/-}$mice which is significantly greater than chance (Fisher's exact test: $\mathrm{p}=2.96 \mathrm{E}-07$ ) and include Ppp3ca, Cdhr4, Hnrnph1, Mapk9, Hnrnpm, Ptpn5, Ip6k1, Uba7, Slc8a3, and Mtap4.

Figure 5. Correlation of differential expression between $114 \mathrm{~kb}$ congenic mice and $\mathrm{H1}^{+/-}$mice. The direction and the magnitude of change in gene expression relative to B6J wildtype were nearly identical between the $114 \mathrm{~kb}$ congenics and $\mathrm{H} 1^{+/-}$mice for every gene [Pearson correlation: $\mathrm{r}=0.960, \mathrm{R}^{2}=0.922, \mathrm{p}=$ 5.41E-12].

\section{Figure 6. Decreased 5' UTR noncoding exon 3 usage of Hnrnph1 in striatal tissue of 114 kb congenic}

mice. Hnrnphl was one of the top-ranked genes showing differential exon usage as indicated via the proportion of total normalized reads counted within an exon bin between $114 \mathrm{~kb}$ congenic mice versus B6J wild-type littermates. To validate differential exon usage, we conducted a set of qPCR experiments targeting the exon junction or the individual exons. Primer sequences, as well as the exon junctions or individual exons they target are provided in Supplemental Table 1. (A) Decreased usage of the junction comprising exons 3 and 4 was detected in $114 \mathrm{~kb}$ congenic mice [unpaired t-test for each exon junction: $\mathrm{t}(13)_{\text {exon } 3-4}=5.65,{ }^{*} \mathrm{p}=7.9 \mathrm{e}-5 ; \mathrm{t}(6)_{\text {exon }}$ $\left.6-7=0.58, \mathrm{p}=0.585 ; \mathrm{t}(6)_{\text {exon } 7-8}=0.20, \mathrm{p}=0.846\right]$. (B-C) To further test specific exons, primers targeting either exon 3 or 4 of Hnrnphl were used to demonstrate that $114 \mathrm{~kb}$ congenic mice showed decreased usage of the 5' 
UTR noncoding exon 3 [unpaired t-test: $\mathrm{t}(13)=3.25,{ }^{*} \mathrm{p}=0.006$ ] but no difference in the first coding exon, exon 4 [unpaired t-test: $\mathrm{t}(13)=1.53, \mathrm{p}=0.150$ ]. Data are represented as the mean \pm S.E.M.

Figure 7. Decrease in hnRNP $H$ protein expression in the striatum of $114 \mathbf{k b}$ congenic mice. The striatum (left and right whole striatum) were dissected from the mice and protein lysates were extracted for protein quantification of hnRNP H using three anti-hnRNP H antibodies from three different companies. (A): Immunoblots showing hnRNP H protein expression in the striatum of $114 \mathrm{~kb}$ congenics and B6J mice. Three antibodies specific for hnRNP H were used. The hnRNP H antibody from Bethyl recognizes the C-terminus of the protein and the one from Santa Cruz recognizes the N-terminus. The epitope site for the antibody from Proteintech is unknown. (B-D): Quantification of the immunoblots shown in A showing a significant decrease in hnRNP $\mathrm{H}$ protein expression in the $114 \mathrm{~kb}$ congenic mice relative to the $\mathrm{B} 6 \mathrm{~J}$ mice when assessed with all three anti-hnRNP H antibodies [unpaired t-test: $\mathrm{t}(10)_{\text {Bethyl }}=5.06,{ }^{*} * \mathrm{p}=0.003 ; \mathrm{t}(10)_{\text {Santa Cruz }}=2.99,{ }^{*} \mathrm{p}=0.014$; $\left.\mathrm{t}(10)_{\text {Proteintech }}=3.02, * \mathrm{p}=0.013\right]$. The expression values for hnRNP H were normalized to total protein staining by ponceau S as a loading control (See Supplemental Figure 1 for ponceau S staining images and densitometry quantification values). The normalized values were normalized to the average of B6J expression values to examine fold-change in expression relative to B6J wild-type. Data are represented as the mean \pm S.EM.

Figure 8. Hnrnph1 variants between the B6J and D2J parental strains. (A): Schematic representation of the position of SNPs and indels in Hnrnphl with the exon numbers listed. The exon with decreased usage in $114 \mathrm{~kb}$ congenic mice is boxed in red. (B): Genomic sequence for part of the Hnrnphl 5' UTR with positions of the three noncoding exons highlighted in green and positions of the 4 variants.

\section{Figure 9. Luciferase reporter assay for the Hnrnph1 promoter in HEK293T and N2a cells to test the}

functional effect of 5 ' UTR variants. Firefly luciferase was used as a reporter to assess the activity of B6JHnrnph1:luc2 versus promoters containing individual 5' UTR variants from the D2J strain. Renilla luciferase was used as an internal control reporter. (A): Schematic representation of the Hnrnph1:luc2 reporter construct that was transfected to HEK293T (B and C) or N2a (D and E) cells. (B): Single D2J variants were engineered within the 5' UTR of the Hnrnphl promoter and had no effect on the luciferase reporter signal in HEK293T cells [one-way ANOVA comparing B6J-Hnnrph1:luc2 against the single D2J variants: $\mathrm{F}(4,50)=3.03$, $\mathrm{p}=$ 0.025; Dunnett's multiple comparison test with comparing each of the four variants with the B6J-Hnnrph1:luc2 control group: $\mathrm{D}_{\text {Dunnett }(\mathrm{T} 7288 \mathrm{C})}=0.36, \mathrm{p}=0.988 ; \mathrm{D}_{\text {Dunnett(GA7546G) }}=1.88, \mathrm{p}=0.199 ;$ DDunnett(T7795G) $=2.11, \mathrm{p}=$ $0.125 ; \mathrm{D}_{\text {Dunnett(G7937C) }}=2.14, \mathrm{p}=0.117$ ]. Data points represent the normalized luciferase signal from 2 independent replicates. (C): Engineering of all four D2J variants (D2J-Hnrnph1:luc2) in the promoter of Hnrnph1 decreased luciferase luminescence relative to B6J-Hnrnph1:luc2 in HEK293T cells [unpaired t-test, $\mathrm{t}(34)=9.39, * \mathrm{p}=5.68 \mathrm{E}-11]$. Data points represent the normalized luciferase signal from 3 independent replicates. (D): Singly engineered D2J variants within the promoter had no effect on luciferase reporter signal in N2a cells [one-way ANOVA comparing B6J-Hnnrph1:luc2 against the single D2J variants: $\mathrm{F}(4,75)=4.42, \mathrm{p}=$ 
0.003; Dunnett's multiple comparison test with comparing each of the four variants with the B6J-Hnnrph1:luc2 control group: $\mathrm{D}_{\text {Dunnett }(\mathrm{T7288C})}=1.18, \mathrm{p}=0.584 ; \mathrm{D}_{\text {Dunnett }(\mathrm{GA7546G})}=2.20, \mathrm{p}=0.100 ; \mathrm{D}_{\text {Dunnett(T7795G) }}=0.18, \mathrm{p}=$ 0.999; $\mathrm{D}_{\text {Dunnett(G7937C) }}=1.79, \mathrm{p}=0.229$ ]. Data points represent the normalized luciferase signal from 2 independent replicates. (E): Engineering all four D2J variants (D2J-Hnrnph1:luc2) within the Hnrnph1 promoter decreased luciferase luminescence relative to the B6J-Hnrnph1:luc2 promoter in N2a cells [unpaired $\mathrm{t}$-test, $\left.\mathrm{t}(46)=5.59,{ }^{*} \mathrm{p}=1.19 \mathrm{E}-06\right]$. Data points are normalized luciferase signal from 3 independent replicates. Data are represented as the mean \pm S.E.M.

Table 1. Differentially expressed genes in the striatum of $114 \mathbf{~ k b}$ congenic mice. This table shows the 69 genes that are differentially expressed in the striatum of $114 \mathrm{~kb}$ congenic mice relative to the B6J wild-type littermates $(\mathrm{p}<0.001)$.

Table 2. Pathway and gene ontology analysis of differential gene expression in $114 \mathrm{~kb}$ congenic mice. This table shows the top 5 KEGG pathways (A) and the top 5 Gene Ontology (GO) biological processes (B) pathways when considering the 69 differentially expressed genes $(\mathrm{p}<0.001)$ between $114 \mathrm{~kb}$ congenic and B6J mice.

Table 3. Genes exhibiting differential exon usage in $114 \mathbf{k b}$ congenic mice. The table shows 35 genes exhibiting differential exon usage in striatal tissue from $114 \mathrm{~kb}$ congenic mice relative to their B6J wild-type littermates $(\mathrm{p}<0.001)$. Differential exon usage was detected using either an F-test $(\mathbf{A})$ or a Simes test $(\mathbf{B})$ in limma (35).

Table 4. Correlation of differential expression between $114 \mathbf{k b}$ congenic and $\mathrm{H1}^{+/-}$mice. Table showing the $\log _{2} \mathrm{FC}$ values for the 21 overlapping genes in the $114 \mathrm{~kb}$ and $\mathrm{H}^{+/-}$. The change in gene expression (up/down) is relative to B6J wild-type littermates.

Table 5. Differential exon usage of Hnrnphl in $114 \mathrm{~kb}$ congenic mice. Table showing the four exon positions of Hnrnphl that display differential exon usage in $114 \mathrm{~kb}$ congenic mice relative to B6J wild-type littermates with $\mathrm{p}<0.05$ using the Simes test. Exon usage was defined as the proportion of total normalized reads per gene that were counted within an exon bin for that gene.

Table 6. SNPs and indels in Hnrnph1 between B6J and D2J. A query for Hnrnph1 genetic variants (SNPs plus indels) between the B6J and D2J parental strains was conducted using the Sanger database query tool (mm10, REL-1505). The variants highlighted in orange are located in close proximity to the 5' UTR noncoding exon 3 and were cloned and tested for functional significance in the luciferase reporter assay. 


\section{REFERENCES}

1. Fogger, S. A. (2019) Methamphetamine Use: A New Wave in the Opioid Crisis? J Addict Nurs 30, 219223

2. Pierce, R. C., Fant, B., Swinford-Jackson, S. E., Heller, E. A., Berrettini, W. H., and Wimmer, M. E. (2018) Environmental, genetic and epigenetic contributions to cocaine addiction.

Neuropsychopharmacology 43, 1471-1480

3. Jensen, K. P. (2016) A Review of Genome-Wide Association Studies of Stimulant and Opioid Use Disorders. Mol.Neuropsychiatry 2, 37-45

4. Gelernter, J., Sherva, R., Koesterer, R., Almasy, L., Zhao, H., Kranzler, H. R., and Farrer, L. (2014) Genome-wide association study of cocaine dependence and related traits: FAM53B identified as a risk gene. Mol.Psychiatry 19, 717-723

5. Dickson, P. E., Miller, M. M., Calton, M. A., Bubier, J. A., Cook, M. N., Goldowitz, D., Chesler, E. J., and Mittleman, G. (2015) Systems genetics of intravenous cocaine self-administration in the BXD recombinant inbred mouse panel. Psychopharmacology (Berl)

6. Harkness, J. H., Shi, X., Janowsky, A., and Phillips, T. J. (2015) Trace Amine-Associated Receptor 1 Regulation of Methamphetamine Intake and Related Traits. Neuropsychopharmacology 40, 2175-2184

7. Miner, N. B., Elmore, J. S., Baumann, M. H., Phillips, T. J., and Janowsky, A. (2017) Trace amineassociated receptor 1 regulation of methamphetamine-induced neurotoxicity. Neurotoxicology 63, 57-69

8. Reed, C., Baba, H., Zhu, Z., Erk, J., Mootz, J. R., Varra, N. M., Williams, R. W., and Phillips, T. J. (2017) A Spontaneous Mutation in Taar1 Impacts Methamphetamine-Related Traits Exclusively in DBA/2 Mice from a Single Vendor. Front Pharmacol 8, 993

9. Shi, X., Walter, N. A. R., Harkness, J. H., Neve, K. A., Williams, R. W., Lu, L., Belknap, J. K., Eshleman, A. J., Phillips, T. J., and Janowsky, A. (2016) Genetic Polymorphisms Affect Mouse and Human Trace Amine-Associated Receptor 1 Function. PLoS ONE 11, e0152581

10. Shi, X., Walter, N. A., Harkness, J. H., Neve, K. A., Williams, R. W., Lu, L., Belknap, J. K., Eshleman, A. J., Phillips, T. J., and Janowsky, A. (2016) Genetic Polymorphisms Affect Mouse and Human Trace Amine-Associated Receptor 1 Function. PLoS One 11, e0152581

11. Loftis, J. M., Lasarev, M., Shi, X., Lapidus, J., Janowsky, A., Hoffman, W. F., and Huckans, M. (2019) Trace amine-associated receptor gene polymorphism increases drug craving in individuals with methamphetamine dependence. PLOS ONE 14, e0220270

12. Nelson, E. C., Agrawal, A., Heath, A. C., Bogdan, R., Sherva, R., Zhang, B., Al-Hasani, R., Bruchas, M. R., Chou, Y. L., Demers, C. H., Carey, C. E., Conley, E. D., Fakira, A. K., Farrer, L. A., Goate, A., Gordon, S., Henders, A. K., Hesselbrock, V., Kapoor, M., Lynskey, M. T., Madden, P. A., Moron, J. A., Rice, J. P., Saccone, N. L., Schwab, S. G., Shand, F. L., Todorov, A. A., Wallace, L., Wang, T., Wray, N. R., Zhou, X., Degenhardt, L., Martin, N. G., Hariri, A. R., Kranzler, H. R., Gelernter, J., Bierut, L. J., 
Clark, D. J., and Montgomery, G. W. (2016) Evidence of CNIH3 involvement in opioid dependence.

Mol.Psychiatry 21, 608-614

13. Zhou, Z., Karlsson, C., Liang, T., Xiong, W., Kimura, M., Tapocik, J. D., Yuan, Q., Barbier, E., Feng, A., Flanigan, M., Augier, E., Enoch, M. A., Hodgkinson, C. A., Shen, P. H., Lovinger, D. M., Edenberg, H. J., Heilig, M., and Goldman, D. (2013) Loss of metabotropic glutamate receptor 2 escalates alcohol consumption. Proc.Natl.Acad.Sci.U.S.A. 110, 16963-16968

14. Hovatta, I., Tennant, R. S., Helton, R., Marr, R. A., Singer, O., Redwine, J. M., Ellison, J. A., Schadt, E. E., Verma, I. M., Lockhart, D. J., and Barlow, C. (2005) Glyoxalase 1 and glutathione reductase 1 regulate anxiety in mice. Nature 438, 662-666

15. Williams, R., Lim, J. E., Harr, B., Wing, C., Walters, R., Distler, M. G., Teschke, M., Wu, C., Wiltshire, T., Su, A. I., Sokoloff, G., Tarantino, L. M., Borevitz, J. O., and Palmer, A. A. (2009) A common and unstable copy number variant is associated with differences in Glo1 expression and anxiety-like behavior. PLoS ONE 4, e4649

16. Distler, M. G., Plant, L. D., Sokoloff, G., Hawk, A. J., Aneas, I., Wuenschell, G. E., Termini, J., Meredith, S. C., Nobrega, M. A., and Palmer, A. A. (2012) Glyoxalase 1 increases anxiety by reducing GABAA receptor agonist methylglyoxal. J. Clin. Invest. 122, 2306-2315

17. McMurray, K. M. J., Du, X., Brownlee, M., and Palmer, A. A. (2016) Neuronal overexpression of Glo1 or amygdalar microinjection of methylglyoxal is sufficient to regulate anxiety-like behavior in mice. Behav.

Brain Res. 301, 119-123

18. de Guglielmo, G., Conlisk, D. E., Barkley-Levenson, A. M., Palmer, A. A., and George, O. (2018) Inhibition of Glyoxalase 1 reduces alcohol self-administration in dependent and nondependent rats. Pharmacol. Biochem. Behav. 167, 36-41

19. McMurray, K. M. J., Sidhu, P. S., Cook, J. M., Arnold, L. A., and Palmer, A. A. (2017) Genetic and pharmacological manipulation of glyoxalase 1 regulates voluntary ethanol consumption in mice. Addict Biol 22, 381-389

20. McMurray, K. M. J., Ramaker, M. J., Barkley-Levenson, A. M., Sidhu, P. S., Elkin, P. K., Reddy, M. K., Guthrie, M. L., Cook, J. M., Rawal, V. H., Arnold, L. A., Dulawa, S. C., and Palmer, A. A. (2018) Identification of a novel, fast-acting GABAergic antidepressant. Mol. Psychiatry 23, 384-391

21. Distler, M. G., Gorfinkle, N., Papale, L. A., Wuenschell, G. E., Termini, J., Escayg, A., Winawer, M. R., and Palmer, A. A. (2013) Glyoxalase 1 and its substrate methylglyoxal are novel regulators of seizure susceptibility. Epilepsia 54, 649-657

22. Wise, R. A. and Bozarth, M. A. (1987) A psychomotor stimulant theory of addiction. Psychological review 94, 469-492 
23. Di Chiara, G. and Imperato, A. (1988) Drugs abused by humans preferentially increase synaptic dopamine concentrations in the mesolimbic system of freely moving rats. Proceedings of the National Academy of Sciences of the United States of America 85, 5274-5278

24. Deminiere, J. M., Piazza, P. V., Le Moal, M., and Simon, H. (1989) Experimental approach to individual vulnerability to psychostimulant addiction. Neurosci.Biobehav.Rev. 13, 141-147

25. Bryant, C. D., Parker, C. C., Zhou, L., Olker, C., Chandrasekaran, R. Y., Wager, T. T., Bolivar, V. J., Loudon, A. S., Vitaterna, M. H., Turek, F. W., and Palmer, A. A. (2012) Csnk1e is a genetic regulator of sensitivity to psychostimulants and opioids. Neuropsychopharmacology 37, 1026-1035

26. Bryant, C. D., Graham, M. E., Distler, M. G., Munoz, M. B., Li, D., Vezina, P., Sokoloff, G., and Palmer, A. A. (2009) A role for casein kinase 1 epsilon in the locomotor stimulant response to methamphetamine. Psychopharmacology 203, 703-711

27. Goldberg, L. R., Kirkpatrick, S. L., Yazdani, N., Luttik, K. P., Lacki, O. A., Babbs, R. K., Jenkins, D. F., Johnson, W. E., and Bryant, C. D. (2017) Casein kinase 1-epsilon deletion increases mu opioid receptordependent behaviors and binge eating1. Genes Brain Behav. 16, 725-738

28. Yazdani, N., Parker, C. C., Shen, Y., Reed, E. R., Guido, M. A., Kole, L. A., Kirkpatrick, S. L., Lim, J. E., Sokoloff, G., Cheng, R., Johnson, W. E., Palmer, A. A., and Bryant, C. D. (2015) Hnrnph1 Is A Quantitative Trait Gene for Methamphetamine Sensitivity. PLoS Genet. 11, e1005713

29. Ruan, Q. T., Yazdani, N., Blum, B. C., Beierle, J. A., Lin, W., Coelho, M. A., Fultz, E. K., Healy, A. F., Shahin, J. R., Kandola, A. K., Luttik, K. P., Zheng, K., Smith, N. J., Cheung, J., Mortazavi, F., Apicco, D. J., Ragu Varman, D., Ramamoorthy, S., Ash, P. E. A., Rosene, D. L., Emili, A., Wolozin, B., Szumlinski, K. K., and Bryant, C. D. (2020) A Mutation in Hnrnph1 That Decreases Methamphetamine-Induced Reinforcement, Reward, and Dopamine Release and Increases Synaptosomal hnRNP H and Mitochondrial Proteins. J. Neurosci. 40, 107-130

30. Parker, C. C., Cheng, R., Sokoloff, G., and Palmer, A. A. (2012) Genome-wide association for methamphetamine sensitivity in an advanced intercross mouse line. Genes Brain Behav. 11, 52-61

31. Iakoubova, O. A., Olsson, C. L., Dains, K. M., Ross, D. A., Andalibi, A., Lau, K., Choi, J., Kalcheva, I., Cunanan, M., Louie, J., Nimon, V., Machrus, M., Bentley, L. G., Beauheim, C., Silvey, S., Cavalcoli, J., Lusis, A. J., and West, D. B. (2001) Genome-tagged mice (GTM): two sets of genome-wide congenic strains. Genomics 74, 89-104

32. Ruan, Q. T., Yazdani, N., Blum, B. C., Beierle, J. A., Lin, W., Coelho, M. A., Fultz, E. K., Healy, A. F., Shahin, J. R., Kandola, A. K., Luttik, K. P., Zheng, K., Smith, N. J., Cheung, J., Mortazavi, F., Apicco, D. J., Ragu Varman, D., Ramamoorthy, S., Ash, P. E. A., Rosene, D. L., Emili, A., Wolozin, B., Szumlinski, K. K., and Bryant, C. D. (2019) A mutation in Hnrnph1 that decreases methamphetamine-induced reinforcement, reward, and dopamine release and increases synaptosomal hnRNP H and mitochondrial proteins. J. Neurosci. 
33. Trapnell, C., Roberts, A., Goff, L., Pertea, G., Kim, D., Kelley, D. R., Pimentel, H., Salzberg, S. L., Rinn, J. L., and Pachter, L. (2012) Differential gene and transcript expression analysis of RNA-seq experiments with TopHat and Cufflinks. Nat.Protoc. 7, 562-578

34. Anders, S., Pyl, P. T., and Huber, W. (2015) HTSeq--a Python framework to work with high-throughput sequencing data. Bioinformatics 31, 166-169

35. Ritchie, M. E., Phipson, B., Wu, D., Hu, Y., Law, C. W., Shi, W., and Smyth, G. K. (2015) limma powers differential expression analyses for RNA-sequencing and microarray studies. Nucleic Acids Res. 43, e47

36. Smyth, G. K., Michaud, J., and Scott, H. S. (2005) Use of within-array replicate spots for assessing differential expression in microarray experiments. Bioinformatics 21, 2067-2075

37. Chen, E. Y., Tan, C. M., Kou, Y., Duan, Q., Wang, Z., Meirelles, G. V., Clark, N. R., and Ma'ayan, A. (2013) Enrichr: interactive and collaborative HTML5 gene list enrichment analysis tool. BMC Bioinformatics 14, 128-2105-14-128

38. Kuleshov, M. V., Jones, M. R., Rouillard, A. D., Fernandez, N. F., Duan, Q., Wang, Z., Koplev, S., Jenkins, S. L., Jagodnik, K. M., Lachmann, A., McDermott, M. G., Monteiro, C. D., Gundersen, G. W., and Ma'ayan, A. (2016) Enrichr: a comprehensive gene set enrichment analysis web server 2016 update. Nucleic Acids Res. 44, W90-97

39. Anders, S., Reyes, A., and Huber, W. (2012) Detecting differential usage of exons from RNA-seq data. Genome Res. 22, 2008-2017

40. Schmittgen, T. D. and Livak, K. J. (2008) Analyzing real-time PCR data by the comparative C(T) method. Nature protocols 3, 1101-1108

41. Rueden, C. T., Schindelin, J., Hiner, M. C., DeZonia, B. E., Walter, A. E., Arena, E. T., and Eliceiri, K. W. (2017) ImageJ2: ImageJ for the next generation of scientific image data. BMC Bioinformatics 18, 529

42. Gilda, J. E. and Gomes, A. V. (2013) Stain-Free total protein staining is a superior loading control to $\beta$ actin for Western blots. Anal. Biochem. 440, 186-188

43. Aldridge, G. M., Podrebarac, D. M., Greenough, W. T., and Weiler, I. J. (2008) The use of total protein stains as loading controls: an alternative to high-abundance single-protein controls in semi-quantitative immunoblotting. J. Neurosci. Methods 172, 250-254

44. Carninci, P., Kasukawa, T., Katayama, S., Gough, J., Frith, M. C., Maeda, N., Oyama, R., Ravasi, T., Lenhard, B., Wells, C., Kodzius, R., Shimokawa, K., Bajic, V. B., Brenner, S. E., Batalov, S., Forrest, A. R. R., Zavolan, M., Davis, M. J., Wilming, L. G., Aidinis, V., Allen, J. E., Ambesi-Impiombato, A., Apweiler, R., Aturaliya, R. N., Bailey, T. L., Bansal, M., Baxter, L., Beisel, K. W., Bersano, T., Bono, H., Chalk, A. M., Chiu, K. P., Choudhary, V., Christoffels, A., Clutterbuck, D. R., Crowe, M. L., Dalla, E., Dalrymple, B. P., de Bono, B., Della Gatta, G., di Bernardo, D., Down, T., Engstrom, P., Fagiolini, M., Faulkner, G., Fletcher, C. F., Fukushima, T., Furuno, M., Futaki, S., Gariboldi, M., Georgii-Hemming, P., Gingeras, T. R., Gojobori, T., Green, R. E., Gustincich, S., Harbers, M., Hayashi, Y., Hensch, T. K., 
Hirokawa, N., Hill, D., Huminiecki, L., Iacono, M., Ikeo, K., Iwama, A., Ishikawa, T., Jakt, M., Kanapin, A., Katoh, M., Kawasawa, Y., Kelso, J., Kitamura, H., Kitano, H., Kollias, G., Krishnan, S. P. T., Kruger, A., Kummerfeld, S. K., Kurochkin, I. V., Lareau, L. F., Lazarevic, D., Lipovich, L., Liu, J., Liuni, S., McWilliam, S., Madan Babu, M., Madera, M., Marchionni, L., Matsuda, H., Matsuzawa, S., Miki, H., Mignone, F., Miyake, S., Morris, K., Mottagui-Tabar, S., Mulder, N., Nakano, N., Nakauchi, H., Ng, P., Nilsson, R., Nishiguchi, S., Nishikawa, S., Nori, F., Ohara, O., Okazaki, Y., Orlando, V., Pang, K. C., Pavan, W. J., Pavesi, G., Pesole, G., Petrovsky, N., Piazza, S., Reed, J., Reid, J. F., Ring, B. Z., Ringwald, M., Rost, B., Ruan, Y., Salzberg, S. L., Sandelin, A., Schneider, C., Schönbach, C., Sekiguchi, K., Semple, C. a. M., Seno, S., Sessa, L., Sheng, Y., Shibata, Y., Shimada, H., Shimada, K., Silva, D., Sinclair, B., Sperling, S., Stupka, E., Sugiura, K., Sultana, R., Takenaka, Y., Taki, K., Tammoja, K., Tan, S. L., Tang, S., Taylor, M. S., Tegner, J., Teichmann, S. A., Ueda, H. R., van Nimwegen, E., Verardo, R., Wei, C. L., Yagi, K., Yamanishi, H., Zabarovsky, E., Zhu, S., Zimmer, A., Hide, W., Bult, C., Grimmond, S. M., Teasdale, R. D., Liu, E. T., Brusic, V., Quackenbush, J., Wahlestedt, C., Mattick, J. S., Hume, D. A., Kai, C., Sasaki, D., Tomaru, Y., Fukuda, S., Kanamori-Katayama, M., Suzuki, M., Aoki, J., Arakawa, T., Iida, J., Imamura, K., Itoh, M., Kato, T., Kawaji, H., Kawagashira, N., Kawashima, T., Kojima, M., Kondo, S., Konno, H., Nakano, K., Ninomiya, N., Nishio, T., Okada, M., Plessy, C., Shibata, K., Shiraki, T., Suzuki, S., Tagami, M., Waki, K., Watahiki, A., Okamura-Oho, Y., Suzuki, H., Kawai, J., Hayashizaki, Y., FANTOM Consortium, and RIKEN Genome Exploration Research Group and Genome Science Group (Genome Network Project Core Group). (2005) The transcriptional landscape of the mammalian genome. Science 309, 1559-1563

45. Yalcin, B. and Flint, J. (2012) Association studies in outbred mice in a new era of full-genome sequencing. Mamm.Genome

46. Bryant, C. D., Ferris, M. T., De Villena,F. P. M., Damaj, M. I., Kumar, V., and Mulligan, M. K. (2018) Reduced complexity cross design for behavioral genetics. In Molecular-Genetic and Statistical Techniques for Behavioral and Neural Research (Gerlai, R. T., ed) pp. 165-190,

47. Bryant, C. D. (2011) The blessings and curses of C57BL/6 substrains in mouse genetic studies. Ann.N.Y.Acad.Sci. 1245, 31-33

48. Mulligan, M. K., Abreo, T., Neuner, S. M., Parks, C., Watkins, C. E., Houseal, M. T., Shapaker, T. M., Hook, M., Tan, H., Wang, X., Ingels, J., Peng, J., Lu, L., Kaczorowski, C. C., Bryant, C. D., Homanics, G. E., and Williams, R. W. (2019) Identification of a functional non-coding variant in the GABAA receptor $\alpha 2$ subunit of the C57BL/6J mouse reference genome: Major implications for neuroscience research.

\section{Frontiers in Genetics 540211}

49. Kumar, V., Kim, K., Joseph, C., Kourrich, S., Yoo, S. H., Huang, H. C., Vitaterna, M. H., de Villena, F. P., Churchill, G., Bonci, A., and Takahashi, J. S. (2013) C57BL/6N mutation in Cytoplasmic FMRP interacting protein 2 regulates cocaine response. Science 342, 1508-1512 
50. Stafford, A. M., Reed, C., Baba, H., Walter, N. A., Mootz, J. R., Williams, R. W., Neve, K. A., Fedorov, L. M., Janowsky, A. J., and Phillips, T. J. (2019) Taar1 gene variants have a causal role in methamphetamine intake and response and interact with Oprm1. Elife 8

51. Xu, J., Lu, Z., Xu, M., Pan, L., Deng, Y., Xie, X., Liu, H., Ding, S., Hurd, Y. L., Pasternak, G. W., Klein, R. J., Cartegni, L., Zhou, W., and Pan, Y. X. (2014) A heroin addiction severity-associated intronic single nucleotide polymorphism modulates alternative pre-mRNA splicing of the mu opioid receptor gene OPRM1 via hnRNPH interactions. J.Neurosci. 34, 11048-11066

52. Araujo, P. R., Yoon, K., Ko, D., Smith, A. D., Qiao, M., Suresh, U., Burns, S. C., and Penalva, L. O. F. (2012) Before It Gets Started: Regulating Translation at the 5' UTR. Comp. Funct. Genomics 2012, 475731

53. Vogel, C., Abreu, R. de S., Ko, D., Le, S.-Y., Shapiro, B. A., Burns, S. C., Sandhu, D., Boutz, D. R., Marcotte, E. M., and Penalva, L. O. (2010) Sequence signatures and mRNA concentration can explain two-thirds of protein abundance variation in a human cell line. Mol. Syst. Biol. 6, 400

54. Chick, J. M., Munger, S. C., Simecek, P., Huttlin, E. L., Choi, K., Gatti, D. M., Raghupathy, N., Svenson, K. L., Churchill, G. A., and Gygi, S. P. (2016) Defining the consequences of genetic variation on a proteome-wide scale. Nature 534, 500-505

55. Chatterjee, S. and Pal, J. K. (2009) Role of 5'- and 3'-untranslated regions of mRNAs in human diseases. Biol. Cell 101, 251-262

56. Kim, Y., Lee, G., Jeon, E., Sohn, E. J., Lee, Y., Kang, H., Lee, D. W., Kim, D. H., and Hwang, I. (2014) The immediate upstream region of the 5'-UTR from the AUG start codon has a pronounced effect on the translational efficiency in Arabidopsis thaliana. Nucleic Acids Res. 42, 485-498

57. Dvir, S., Velten, L., Sharon, E., Zeevi, D., Carey, L. B., Weinberger, A., and Segal, E. (2013) Deciphering the rules by which 5'-UTR sequences affect protein expression in yeast. Proc. Natl. Acad. Sci. U.S.A. 110, E2792-2801

58. Jackson, R. J., Hellen, C. U. T., and Pestova, T. V. (2010) The mechanism of eukaryotic translation initiation and principles of its regulation. Nat. Rev. Mol. Cell Biol. 11, 113-127

59. Steri, M., Idda, M. L., Whalen, M. B., and Orrù, V. (2018) Genetic variants in mRNA untranslated regions. Wiley Interdiscip Rev RNA 9, e1474

60. Dassi, E. (2017) Handshakes and Fights: The Regulatory Interplay of RNA-Binding Proteins. Front Mol Biosci 4, 67

61. Cook, K. B., Kazan, H., Zuberi, K., Morris, Q., and Hughes, T. R. (2011) RBPDB: a database of RNAbinding specificities. Nucleic Acids Res. 39, D301-308

62. Huelga, S. C., Vu, A. Q., Arnold, J. D., Liang, T. Y., Liu, P. P., Yan, B. Y., Donohue, J. P., Shiue, L., Hoon, S., Brenner, S., Ares, M., Jr, and Yeo, G. W. (2012) Integrative genome-wide analysis reveals cooperative regulation of alternative splicing by hnRNP proteins. Cell.Rep. 1, 167-178 
bioRxiv preprint doi: https://doi.org/10.1101/2020.01.11.902908; this version posted April 16, 2020. The copyright holder for this preprint (which was not certified by peer review) is the author/funder, who has granted bioRxiv a license to display the preprint in perpetuity. It is made available under aCC-BY-NC-ND 4.0 International license.

63. Fisette, J. F., Toutant, J., Dugre-Brisson, S., Desgroseillers, L., and Chabot, B. (2010) hnRNP A1 and hnRNP H can collaborate to modulate 5' splice site selection. RNA 16, 228-238 
Table 1. Differentially expressed genes in the striatum of $114 \mathbf{~ k b}$ congenic mice. This table shows the 69 genes that are differentially expressed in the striatum of $114 \mathrm{~kb}$ congenic mice relative to the B6J wild-type littermates $(\mathrm{p}<0.001)$.

\begin{tabular}{|c|c|c|c|c|c|c|}
\hline Gene & $\log F C$ & AveExpr & $\mathbf{t}$ & p value & Adjusted p value & B \\
\hline Baiap3 & -0.534 & 4.730 & -5.500 & $1.14 \mathrm{E}-06$ & 0.0162 & 5.180 \\
\hline Hapl & -0.302 & 7.192 & -5.065 & $5.36 \mathrm{E}-06$ & 0.0271 & 3.919 \\
\hline$W d r 6$ & -0.348 & 5.830 & -5.047 & $5.72 \mathrm{E}-06$ & 0.0271 & 3.856 \\
\hline Zcchc12 & -0.225 & 7.100 & -4.726 & $1.75 \mathrm{E}-05$ & 0.0623 & 2.815 \\
\hline Trpc4 & -0.562 & 3.444 & -4.556 & $3.13 \mathrm{E}-05$ & 0.0713 & 1.838 \\
\hline Tmem130 & -0.270 & 7.087 & -4.545 & $3.26 \mathrm{E}-05$ & 0.0713 & 2.237 \\
\hline Prkcd & -0.524 & 4.363 & -4.523 & $3.51 \mathrm{E}-05$ & 0.0713 & 2.076 \\
\hline Trp53inp2 & 0.183 & 8.099 & 4.399 & $5.33 \mathrm{E}-05$ & 0.0857 & 1.752 \\
\hline Wnkl & 0.123 & 8.451 & 4.347 & $6.35 \mathrm{E}-05$ & 0.0857 & 1.578 \\
\hline$S c d 1$ & 0.184 & 7.767 & 4.338 & $6.55 \mathrm{E}-05$ & 0.0857 & 1.568 \\
\hline Zicl & -0.630 & 4.393 & -4.317 & $7.03 \mathrm{E}-05$ & 0.0857 & 1.482 \\
\hline Cacng5 & -0.454 & 3.203 & -4.291 & $7.65 \mathrm{E}-05$ & 0.0857 & 1.005 \\
\hline Col6a3 & -0.892 & 2.255 & -4.259 & $8.51 \mathrm{E}-05$ & 0.0857 & 0.249 \\
\hline Kcnj2 & 0.201 & 6.042 & 4.259 & $8.53 \mathrm{E}-05$ & 0.0857 & 1.378 \\
\hline Ecell & -0.187 & 5.713 & -4.203 & 0.000102 & 0.0857 & 1.220 \\
\hline Fos & 0.994 & 2.801 & 4.201 & 0.000103 & 0.0857 & 0.773 \\
\hline Lbhd2 & -2.694 & -0.765 & -4.196 & 0.000105 & 0.0857 & -1.978 \\
\hline Magel2 & -0.704 & 1.965 & -4.186 & 0.000108 & 0.0857 & 0.001 \\
\hline Zic2 & -0.692 & 2.885 & -4.118 & 0.000136 & 0.0986 & 0.386 \\
\hline Osbpl8 & 0.115 & 8.486 & 4.099 & 0.000144 & 0.0986 & 0.808 \\
\hline$Q k$ & 0.152 & 8.422 & 4.097 & 0.000145 & 0.0986 & 0.805 \\
\hline Gatm & 0.193 & 7.062 & 4.056 & 0.000166 & 0.1074 & 0.730 \\
\hline Nrp2 & -0.391 & 3.477 & -4.005 & 0.000196 & 0.1127 & 0.423 \\
\hline $\operatorname{Itm} 2 c$ & -0.089 & 10.023 & -4.001 & 0.000198 & 0.1127 & 0.461 \\
\hline$E z r$ & -0.170 & 6.308 & -3.982 & 0.000211 & 0.1127 & 0.537 \\
\hline Zic4 & -0.971 & 1.787 & -3.980 & 0.000213 & 0.1127 & -0.702 \\
\hline Ermn & 0.240 & 6.924 & 3.978 & 0.000214 & 0.1127 & 0.502 \\
\hline Zcchcl8 & -0.103 & 8.156 & -3.954 & 0.000231 & 0.1175 & 0.381 \\
\hline Pnmal2 & -0.226 & 7.963 & -3.925 & 0.000253 & 0.1216 & 0.300 \\
\hline Fth1 & 0.169 & 10.805 & 3.922 & 0.000256 & 0.1216 & 0.196 \\
\hline Dlxl & -0.701 & 3.098 & -3.895 & 0.000279 & 0.1252 & -0.051 \\
\hline Icam5 & -0.104 & 8.147 & -3.891 & 0.000283 & 0.1252 & 0.195 \\
\hline Sept7 & 0.107 & 8.420 & 3.883 & 0.000290 & 0.1252 & 0.162 \\
\hline Pcdh8 & -0.391 & 3.388 & -3.853 & 0.000319 & 0.1337 & 0.027 \\
\hline Ttll7 & 0.104 & 7.896 & 3.840 & 0.000332 & 0.1346 & 0.055 \\
\hline Rasdl & -0.842 & 1.393 & -3.830 & 0.000344 & 0.1346 & -1.180 \\
\hline Tspan2 & 0.175 & 7.668 & 3.824 & 0.000350 & 0.1346 & 0.019 \\
\hline Slc22a17 & -0.120 & 9.192 & -3.810 & 0.000366 & 0.1371 & -0.082 \\
\hline Gpm6b & 0.091 & 10.728 & 3.777 & 0.000406 & 0.1378 & -0.233 \\
\hline Tрpp & 0.091 & 9.176 & 3.775 & 0.000409 & 0.1378 & -0.184 \\
\hline Cadm2 & 0.134 & 7.765 & 3.764 & 0.000423 & 0.1378 & -0.161 \\
\hline
\end{tabular}




\begin{tabular}{|c|c|c|c|c|c|c|}
\hline Gprasp1 & -0.102 & 9.355 & -3.762 & 0.000426 & 0.1378 & -0.230 \\
\hline Adcyl & 0.111 & 8.611 & 3.761 & 0.000426 & 0.1378 & -0.201 \\
\hline Npas4 & 0.694 & 4.629 & 3.758 & 0.000431 & 0.1378 & -0.052 \\
\hline Rapgef4 & 0.146 & 9.876 & 3.744 & 0.000451 & 0.1378 & -0.299 \\
\hline Tro & -0.103 & 7.983 & -3.744 & 0.000451 & 0.1378 & -0.233 \\
\hline Grin2a & 0.232 & 4.844 & 3.736 & 0.000462 & 0.1378 & -0.111 \\
\hline Scn5a & -0.522 & 2.614 & -3.734 & 0.000465 & 0.1378 & -0.572 \\
\hline Maged1 & -0.152 & 8.935 & -3.694 & 0.000526 & 0.1528 & -0.410 \\
\hline Kcna2 & 0.109 & 8.165 & 3.684 & 0.000543 & 0.1547 & -0.410 \\
\hline Ano3 & 0.105 & 9.169 & 3.668 & 0.000571 & 0.1594 & -0.493 \\
\hline Slit1 & -0.361 & 4.198 & -3.652 & 0.000601 & 0.1645 & -0.361 \\
\hline Oip5os1 & 0.146 & 6.009 & 3.621 & 0.000661 & 0.1747 & -0.483 \\
\hline Lpgat1 & 0.090 & 8.070 & 3.620 & 0.000663 & 0.1747 & -0.589 \\
\hline Ptprd & 0.143 & 7.600 & 3.602 & 0.000700 & 0.1812 & -0.619 \\
\hline Ngb & -0.792 & 1.543 & -3.596 & 0.000714 & 0.1815 & -1.419 \\
\hline Rgs7bp & 0.118 & 9.071 & 3.589 & 0.000729 & 0.1821 & -0.716 \\
\hline Camk4 & 0.101 & 9.316 & 3.583 & 0.000744 & 0.1825 & -0.743 \\
\hline Thsd7a & 0.117 & 7.467 & 3.561 & 0.000793 & 0.1892 & -0.728 \\
\hline Hipk2 & 0.191 & 5.988 & 3.560 & 0.000798 & 0.1892 & -0.651 \\
\hline Pnck & -0.209 & 5.758 & -3.542 & 0.000843 & 0.1968 & -0.686 \\
\hline Camk2n1 & 0.106 & 10.768 & 3.519 & 0.000904 & 0.2022 & -0.979 \\
\hline Ret & -0.589 & 2.081 & -3.516 & 0.000911 & 0.2022 & -1.307 \\
\hline Zeb2 & 0.142 & 6.285 & 3.512 & 0.000922 & 0.2022 & -0.798 \\
\hline Bcas1 & 0.185 & 8.413 & 3.507 & 0.000937 & 0.2022 & -0.920 \\
\hline Samd5 & 0.260 & 3.992 & 3.507 & 0.000937 & 0.2022 & -0.747 \\
\hline S100b & 0.206 & 7.036 & 3.498 & 0.000964 & 0.2033 & -0.884 \\
\hline Gpc3 & -0.594 & 1.672 & -3.495 & 0.000971 & 0.2033 & -1.579 \\
\hline Gpi1 & -0.136 & 9.102 & -3.488 & 0.000991 & 0.2045 & -1.003 \\
\hline & & & & & & \\
\hline
\end{tabular}


Table 2. Pathway and gene ontology analysis of differential gene expression in $114 \mathbf{~ k b}$ congenic mice. This table shows the top 5 KEGG pathways (A) and the top 5 Gene Ontology (GO) biological processes (B) pathways when considering the 69 differentially expressed genes $(p<0.001)$ between $114 \mathrm{~kb}$ congenic and B6J mice.

\begin{tabular}{|c|c|c|c|}
\hline \multicolumn{4}{|l|}{ (A): KEGG Pathways } \\
\hline Name & p value & Overlap & Genes \\
\hline Oxytocin signaling pathway & $1.92 \mathrm{E}-04$ & $5 / 154$ & $\begin{array}{l}\text { Camk4, Fos, Adcyl, Kcnj2, } \\
\text { Cacng5 }\end{array}$ \\
\hline Circadian entrainment & $3.82 \mathrm{E}-04$ & $4 / 99$ & Grin2a, Rasdl, Fos, Adcyl \\
\hline Cholinergic synapse & $6.29 \mathrm{E}-04$ & $4 / 113$ & Camk4, Fos, Adcyl, Kcnj2 \\
\hline cAMP signaling pathway & 8.10E-04 & $5 / 211$ & $\begin{array}{l}\text { Grin2a, Camk4, Fos, Adcyl, } \\
\text { Rapgef4 }\end{array}$ \\
\hline Long-term potentiation & $1.71 \mathrm{E}-03$ & $3 / 67$ & Grin $2 a$, Camk4, Adcyl \\
\hline \multicolumn{4}{|l|}{ (B): GO Biological Processes } \\
\hline Name & p value & Overlap & Genes \\
\hline $\begin{array}{c}\text { peptidyl-threonine } \\
\text { phosphorylation (GO:0018107) }\end{array}$ & $1.92 \mathrm{E}-04$ & $4 / 68$ & Pnck, Wnkl, Prkcd, Hipk2 \\
\hline $\begin{array}{l}\text { regulation of non-motile cilium } \\
\text { assembly (GO:1902855) }\end{array}$ & $3.82 \mathrm{E}-04$ & $2 / 6$ & Sept7, Hapl \\
\hline $\begin{array}{l}\text { peptidyl-threonine modification } \\
\text { (GO:0018210) }\end{array}$ & $6.29 \mathrm{E}-04$ & $4 / 89$ & Pnck, Wnkl, Prkcd, Hipk2 \\
\hline $\begin{array}{c}\text { regulation of synaptic } \\
\text { transmission, GABAergic } \\
\text { (GO:0032228) }\end{array}$ & $8.10 \mathrm{E}-04$ & $2 / 11$ & Npas4, Hapl \\
\hline brain development (GO:0007420) & $1.71 \mathrm{E}-03$ & $4 / 119$ & Grin2a, Zic2, Zic1, Hapl \\
\hline
\end{tabular}


Table 3. Genes exhibiting differential exon usage in $114 \mathrm{~kb}$ congenic mice. The table shows 35 genes exhibiting differential exon usage in striatal tissue from $114 \mathrm{~kb}$ congenic mice relative to their B6J wild-type littermates $(\mathrm{p}<0.001)$. Differential exon usage was detected using either an F-test (A) or a Simes test (B) in limma (35).

\begin{tabular}{|c|c|c|c|c|c|}
\hline \multicolumn{6}{|l|}{ (A): F-test $(p<0.001)$} \\
\hline Gene & Fstat & Fstat_P & Fstat_FDR & Simes_P & Simes_FDR \\
\hline Рpp3ca & 2.87 & $5.12 \mathrm{E}-07$ & 0.0092 & $1.30 \mathrm{E}-09$ & $2.30 \bar{E}-05$ \\
\hline $\begin{array}{l}\text { Cdhr4, Ip6k1, Uba7, } \\
\text { Gm20661, Gm20662 }\end{array}$ & 1.65 & $1.36 \mathrm{E}-06$ & 0.012 & 0.0015 & 1 \\
\hline Hnrnphl & 2.19 & $7.50 \mathrm{E}-06$ & 0.045 & 0.0055 & 1 \\
\hline Mrps 14 & 4.92 & $2.67 \mathrm{E}-05$ & 0.1 & $4.10 \mathrm{E}-05$ & 0.19 \\
\hline Pfdn5, Mygl & 2.1 & $2.89 \mathrm{E}-05$ & 0.1 & 0.028 & 1 \\
\hline Scn3a & 2.14 & $4.26 \mathrm{E}-05$ & 0.13 & 0.002 & 1 \\
\hline Chn2 & 2.53 & $5.58 \mathrm{E}-05$ & 0.14 & 0.026 & 1 \\
\hline Myo5b & 1.89 & $7.13 \mathrm{E}-05$ & 0.16 & 0.036 & 1 \\
\hline Mapk9 & 2.33 & $1.20 \mathrm{E}-04$ & 0.21 & 0.022 & 1 \\
\hline Calm2 & 3.6 & $1.30 \mathrm{E}-04$ & 0.21 & 0.0024 & 1 \\
\hline Hnrnpm, March2 & 1.83 & $1.40 \mathrm{E}-04$ & 0.21 & 0.014 & 1 \\
\hline$C d c 42 b p a$ & 1.75 & $1.40 \mathrm{E}-04$ & 0.21 & 0.18 & 1 \\
\hline Arrdcl & 2.11 & $1.90 \mathrm{E}-04$ & 0.26 & 0.21 & 1 \\
\hline Igbpl & 3.98 & $3.50 \mathrm{E}-04$ & 0.43 & 0.014 & 1 \\
\hline Sptbn1 & 1.84 & $3.60 \mathrm{E}-04$ & 0.43 & 0.017 & 1 \\
\hline$T m 4 s f 1$ & 3.64 & $4.30 \mathrm{E}-04$ & 0.49 & 0.018 & 1 \\
\hline Ptpn5 & 1.94 & $5.60 \mathrm{E}-04$ & 0.6 & 0.2 & 1 \\
\hline \multicolumn{6}{|l|}{ (B): Simes $(p<0.001)$} \\
\hline Gene & Fstat & Fstat_P & Fstat_FDR & Simes_P & Simes_FDR \\
\hline Ppp3ca & 2.87 & $5.12 \mathrm{E}-07$ & 0.0092 & $1.30 \mathrm{E}-09$ & $2.30 \mathrm{E}-05$ \\
\hline Tspan32 & 2.96 & 0.0013 & 1 & $2.27 \mathrm{E}-05$ & 0.19 \\
\hline Mrps14 & 4.92 & $2.67 \mathrm{E}-05$ & 0.1 & $4.09 \mathrm{E}-05$ & 0.19 \\
\hline Txn2 & 1.59 & 0.048 & 1 & $4.13 \mathrm{E}-05$ & 0.19 \\
\hline Map2 & 1.6 & 0.0018 & 1 & $1.50 \mathrm{E}-04$ & 0.53 \\
\hline Map4, Mtap4 & 1.57 & 0.007 & 1 & $1.80 \mathrm{E}-04$ & 0.54 \\
\hline Slc8a3 & 2.88 & 0.0011 & 1 & $2.20 \mathrm{E}-04$ & 0.57 \\
\hline Alpk3 & 1.76 & 0.052 & 1 & $3.80 \mathrm{E}-04$ & 0.81 \\
\hline Jaml & 2.74 & 0.006 & 1 & $4.10 \mathrm{E}-04$ & 0.81 \\
\hline Dph1, Ovca2 & 1.29 & 0.15 & 1 & $4.90 \mathrm{E}-04$ & 0.87 \\
\hline $\operatorname{Rab21}$ & 2.69 & 0.15 & 1 & $5.40 \mathrm{E}-04$ & 0.89 \\
\hline Usp24 & 0.83 & 0.86 & 1 & $9.70 \mathrm{E}-04$ & 1 \\
\hline
\end{tabular}


Table 4. Correlation of differential expression between $114 \mathrm{~kb}$ congenic and $\mathrm{H1}^{+/-}$mice. Table showing the $\log _{2} \mathrm{FC}$ values for the 21 overlapping genes in the $114 \mathrm{~kb}$ and $\mathrm{H}^{+/-}$. The change in gene expression (up/down) is relative to B6J wild-type littermates.

\begin{tabular}{|c|c|c|}
\hline Gene & $\begin{array}{c}\mathbf{1 1 4} \mathbf{~ k b} \\
\mathbf{l o g}_{2} \mathbf{F C}\end{array}$ & $\begin{array}{c}\mathbf{H}^{+/-} \\
\mathbf{l o g}_{2} \mathbf{F C}\end{array}$ \\
\hline Magel2 & -0.704 & -0.857 \\
\hline Dlx1 & -0.701 & -0.686 \\
\hline Zic2 & -0.692 & -0.811 \\
\hline Zic1 & -0.630 & -0.897 \\
\hline Trpc4 & -0.562 & -0.786 \\
\hline Prkcd & -0.524 & -0.528 \\
\hline Wdr6 & -0.348 & -0.420 \\
\hline Hap1 & -0.302 & -0.380 \\
\hline Zcchc12 & -0.225 & -0.297 \\
\hline Pnck & -0.209 & -0.353 \\
\hline Ecel1 & -0.187 & -0.596 \\
\hline Zcchc18 & -0.103 & -0.154 \\
\hline Camk4 & 0.101 & 0.311 \\
\hline Ano3 & 0.105 & 0.212 \\
\hline Kcna2 & 0.109 & 0.247 \\
\hline Osbpl8 & 0.115 & 0.129 \\
\hline Thsd7a & 0.117 & 0.303 \\
\hline Rgs7bp & 0.118 & 0.335 \\
\hline Wnk1 & 0.123 & 0.220 \\
\hline Cadm2 & 0.134 & 0.192 \\
\hline Oip5os1 & 0.146 & 0.369 \\
\hline
\end{tabular}


Table 5. Differential exon usage of Hnrnphl in $114 \mathrm{~kb}$ congenic mice. Table showing the four exon positions of Hnrnphl that display differential exon usage in $114 \mathrm{~kb}$ congenic mice relative to B6J wild-type littermates with $\mathrm{p}<0.05$ using the Simes test. Exon usage was defined as the proportion of total normalized reads per gene that were counted within an exon bin for that gene.

\begin{tabular}{|c|c|c|c|c|}
\hline Position (mm10) & $\begin{array}{c}\text { Corresponding } \\
\text { exon junction }\end{array}$ & $\log _{2}$ FC & p value & FDR \\
\hline chr11:50,377,719-50,377,750 & $3-4$ & -0.484 & 0.018 & 1 \\
\hline chr11:50,380,191-50,380,825 & $6-7$ & 0.137 & 0.001 & 1 \\
\hline chr11:50,381,598-50,382,137 & $7-8$ & 0.094 & 0.017 & 1 \\
\hline $\operatorname{chr} 11: 50,382,138-50,382,536$ & $7-8$ & 0.167 & $3.80 \mathrm{E}-04$ & 1 \\
\hline
\end{tabular}


Table 6. SNPs and indels in Hnrnph1 between B6J and D2J. A query for Hnrnph1 genetic variants (SNPs plus indels) between the B6J and D2J parental strains was conducted using the Sanger database query tool (mm10, REL-1505). The variants highlighted in orange are located in close proximity to the 5' UTR noncoding exon 3 and were cloned and tested for functional significance in the luciferase reporter assay.

\begin{tabular}{|c|c|c|c|c|}
\hline $\begin{array}{c}\text { Position } \\
(\mathbf{m m 1 0})\end{array}$ & dbSNP & C57BL/6J & DBA/2J & Type \\
\hline $50,377,288$ & rs29411274 & T & $\mathrm{C}^{*}$ & SNP; intron variant \\
\hline $50,377,546$ & $\mathrm{rs} 221962608 ; \mathrm{rs} 224352813$ & $\mathrm{GA}$ & $\mathrm{G}^{*}$ & Indel; intron variant \\
\hline $50,377,795$ & $\mathrm{rs} 29475617$ & $\mathrm{~T}$ & $\mathrm{G}^{*}$ & SNP; 5'UTR variant \\
\hline $50,377,937$ & $\mathrm{rs} 257760362$ & $\mathrm{G}$ & $\mathrm{C}^{*}$ & SNP; intron variant \\
\hline $50,378,499$ & $\mathrm{rs} 245024332$ & $\mathrm{~T}$ & $\mathrm{C}^{*}$ & SNP; intron variant \\
\hline $50,379,377$ & $\mathrm{rs} 387789478 ; \mathrm{rs} 233140941$ & $\mathrm{GTT}$ & $\mathrm{GT}^{*}$ & Indel; intron variant \\
\hline $50,383,262$ & $\mathrm{rs} 13481018$ & $\mathrm{C}$ & $\mathrm{T}^{*}$ & SNP; synonymous variant \\
\hline $50,383,443$ & $\mathrm{rs} 226185912$ & $\mathrm{ATG}$ & $\mathrm{A}^{*}$ & Indel; intron variant \\
\hline $50,383,487$ & $\mathrm{rs} 211965589$ & $\mathrm{~T}$ & $\mathrm{TA} *$ & Indel; intron variant \\
\hline $50,384,116$ & $\mathrm{rs} 13461679$ & $\mathrm{G}$ & $\mathrm{A}^{*}$ & SNP; intron variant \\
\hline $50,384,175$ & $\mathrm{rs} 263842089$ & $\mathrm{~T}$ & $\mathrm{TAGATG}$ & Indel; intron variant \\
\hline $50,384,378$ & $\mathrm{rs} 29466249$ & $\mathrm{~A}$ & $\mathrm{~T}^{*}$ & SNP; intron variant \\
\hline $50,385,052$ & $\mathrm{rs} 247364036$ & $\mathrm{GTT}$ & $\mathrm{G}^{*}$ & Indel; intron variant \\
\hline $50,385,066$ & $\mathrm{rs} 51675672$ & $\mathrm{G}$ & $\mathrm{T}^{*}$ & SNP; intron variant \\
\hline $50,386,305$ & $\mathrm{rs} 229280897$ & $\mathrm{~T}$ & $\mathrm{t} / \mathrm{c}^{*}$ & SNP; 3'UTR variant \\
\hline $50,386,341$ & $\mathrm{rs} 211943719 ; \mathrm{rs} 240064076$ & $\mathrm{CTT}$ & $\mathrm{CTTT}^{*}$ & Indel; 3'UTR variant \\
\hline
\end{tabular}


A $114 \mathrm{~kb}$ congenic

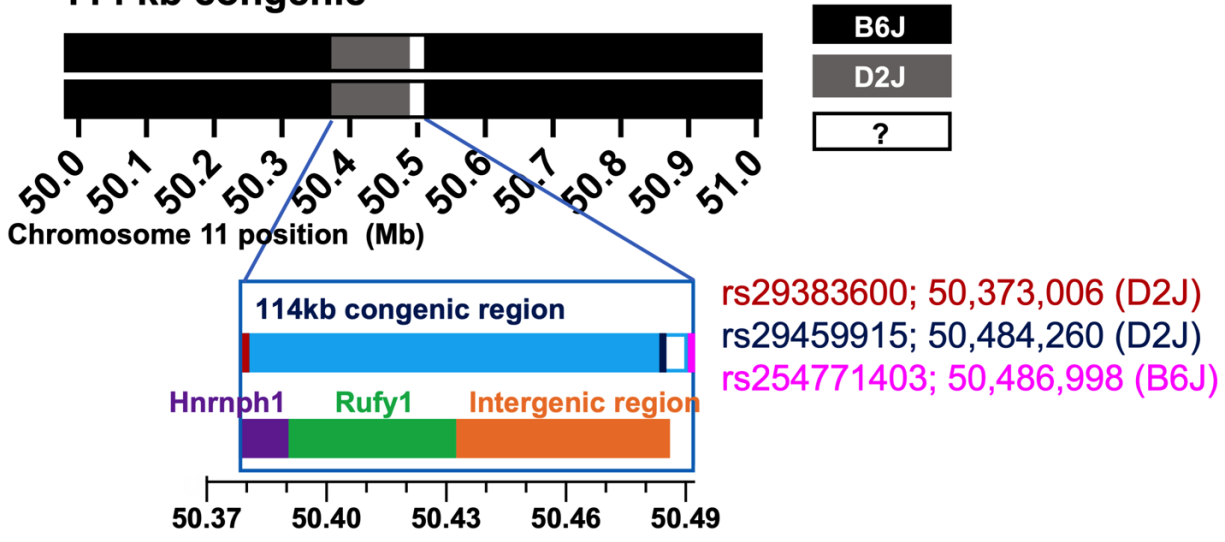

B

Day 1

ह

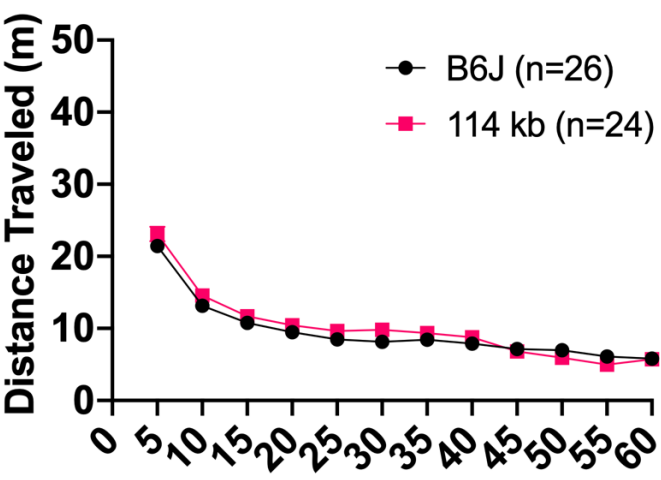

Time (min) Post Injection

E

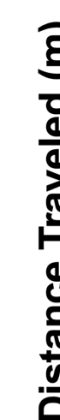

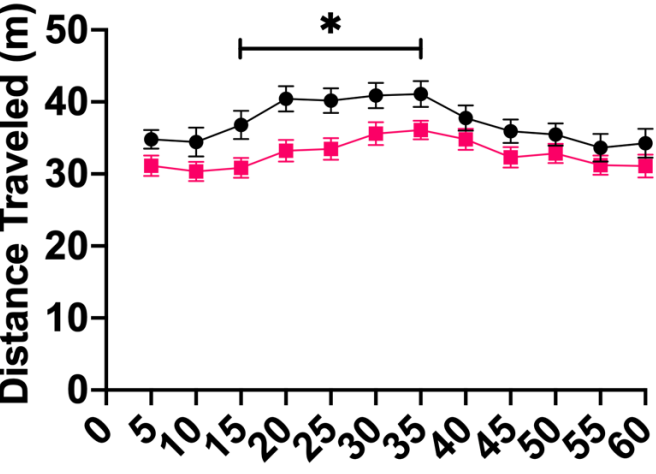

Time (min) Post Injection
C Day 2

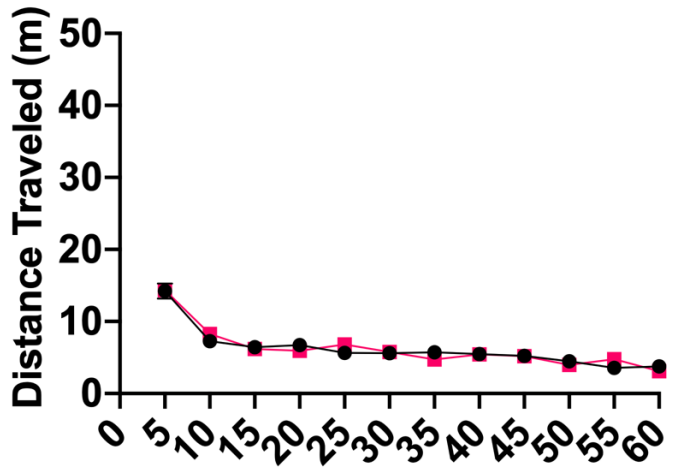

Time (min) Post Injection

F

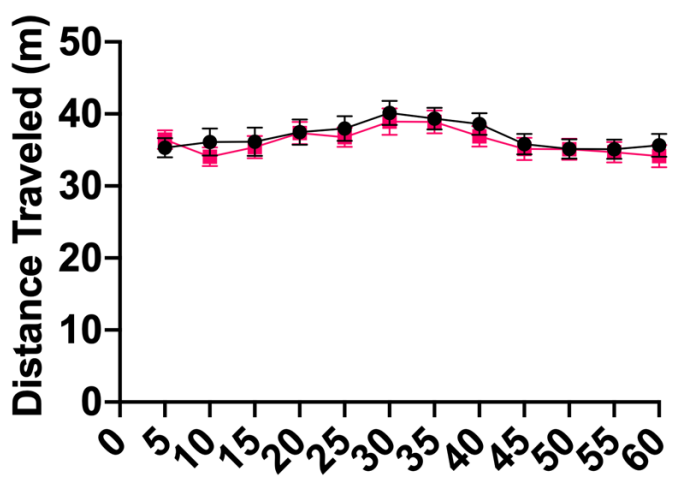

Time (min) Post Injection
D Day 3

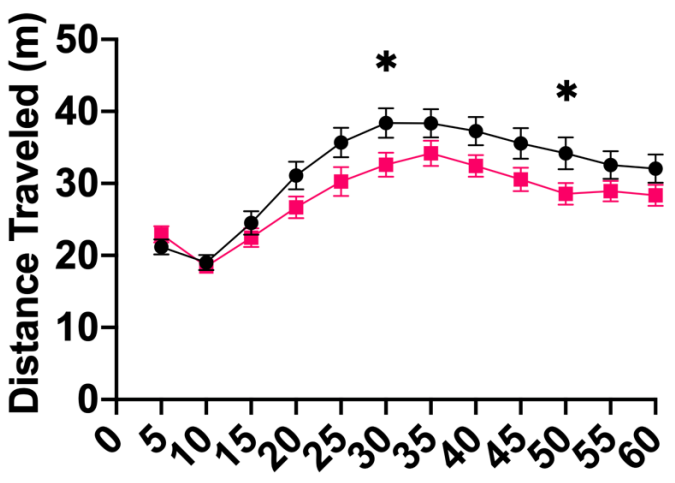

Time (min) Post Injection

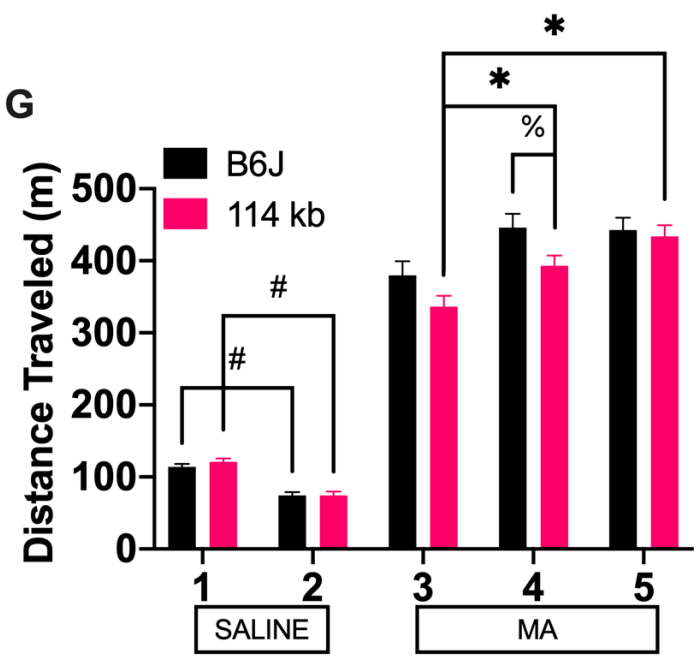

Day 


\section{Enriched Terms}

Ppp3ca

\author{
Calm2
}

MAPK2

SLC8A3

Txn2

\section{$\begin{array}{llllllllll}1 & 2 & 3 & 4 & 5 & 6 & 7 & 8 & 9 & 10\end{array}$}

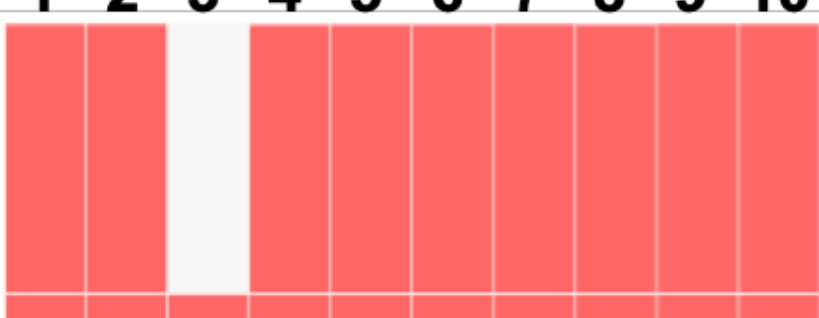

1. C-type lectin receptor signaling pathway $(p=9.82 E-04)$

2. Dopaminergic synapse $(p=1.68 \mathrm{E}-03)$

3. Fluid shear stress and atherosclerosis $(p=1.98 E-03)$

4. cGMP-PKG signaling pathway $(p=3.34 \mathrm{E}-03)$

5. Tuberculosis $(p=3.68 \mathrm{E}-03)$

6. Calcium signaling pathway $(p=4.35 E-03)$

7. Long-term potentiation $(p=6.13 \mathrm{E}-03)$

8. Amphetamine addiction ( $p=6.30 \mathrm{E}-03)$

9. Kaposi sarcoma-associated herpesvirus infection $(p=6.30 \mathrm{E}-03)$

10. Renin secretion ( $p=7.82 E-03)$ 
bioRxiv preprint doi: https://doi.org/10.1101/2020.01.11.902\$08;"thisversian_poste/ April 16, 2020. The copyright holder for this preprint (which was not certified by peer review) is the author/funder, wh $\mathrm{h}$. nd available under aCC-BUN 4.0 International license.

A

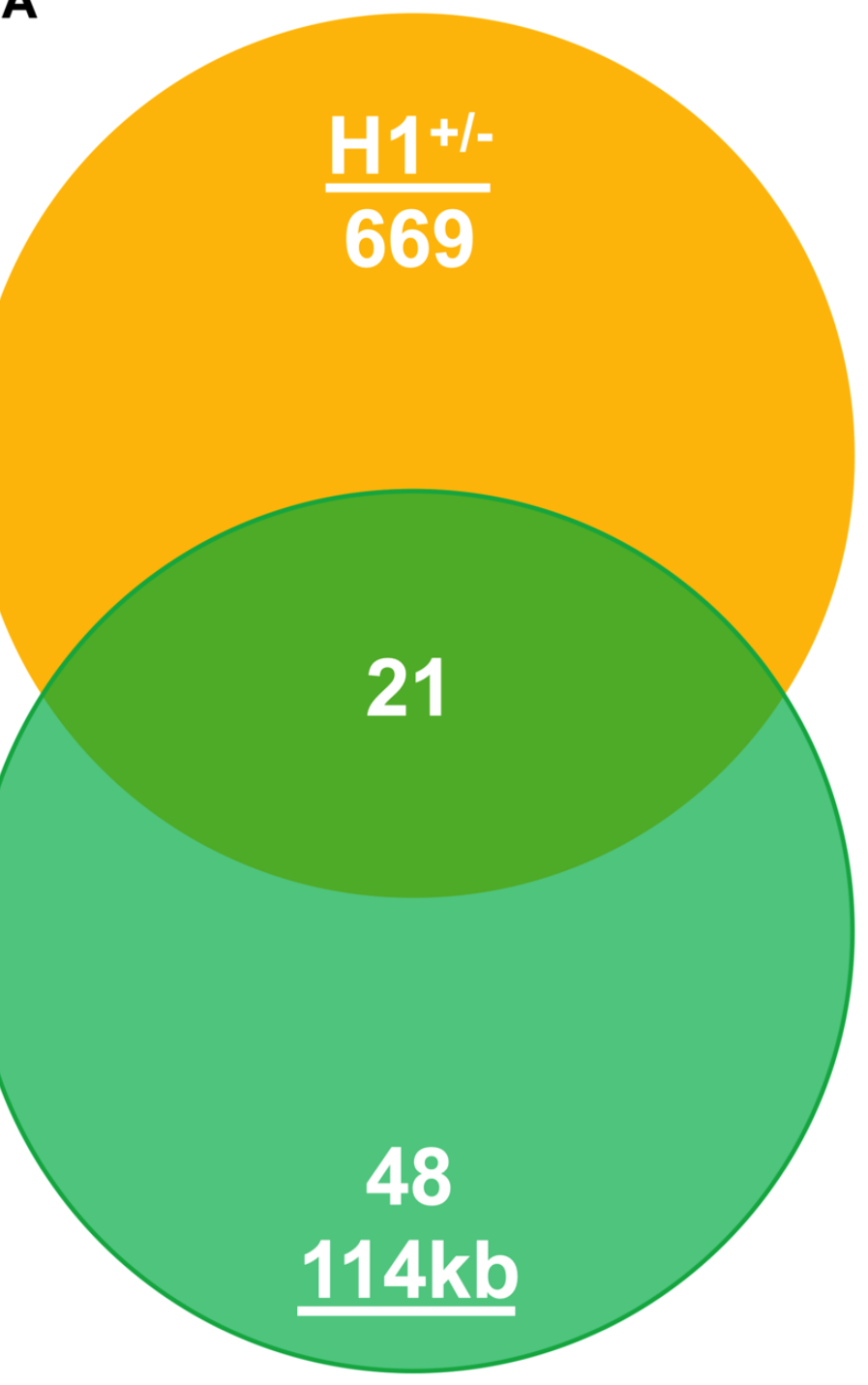

B

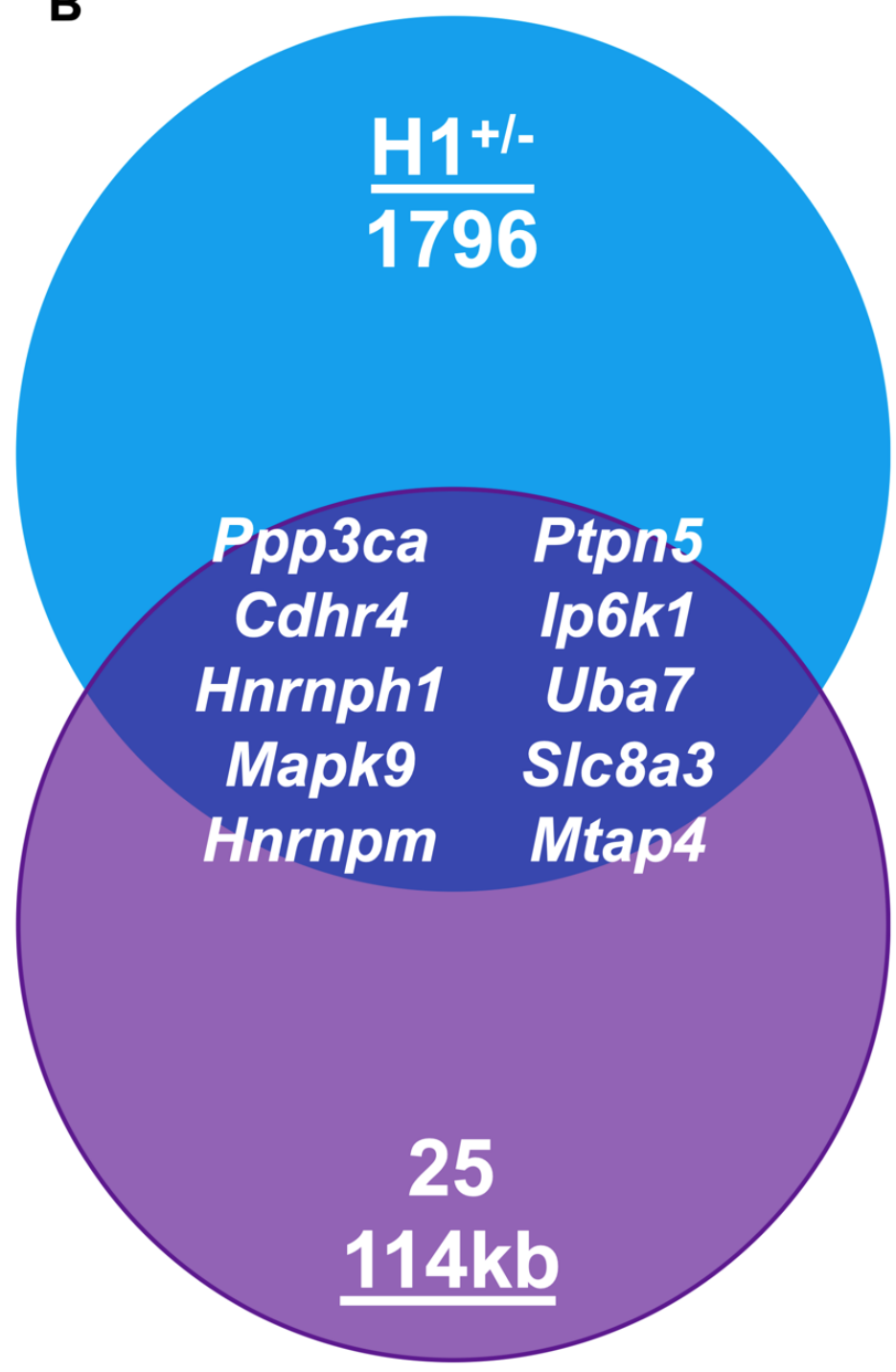




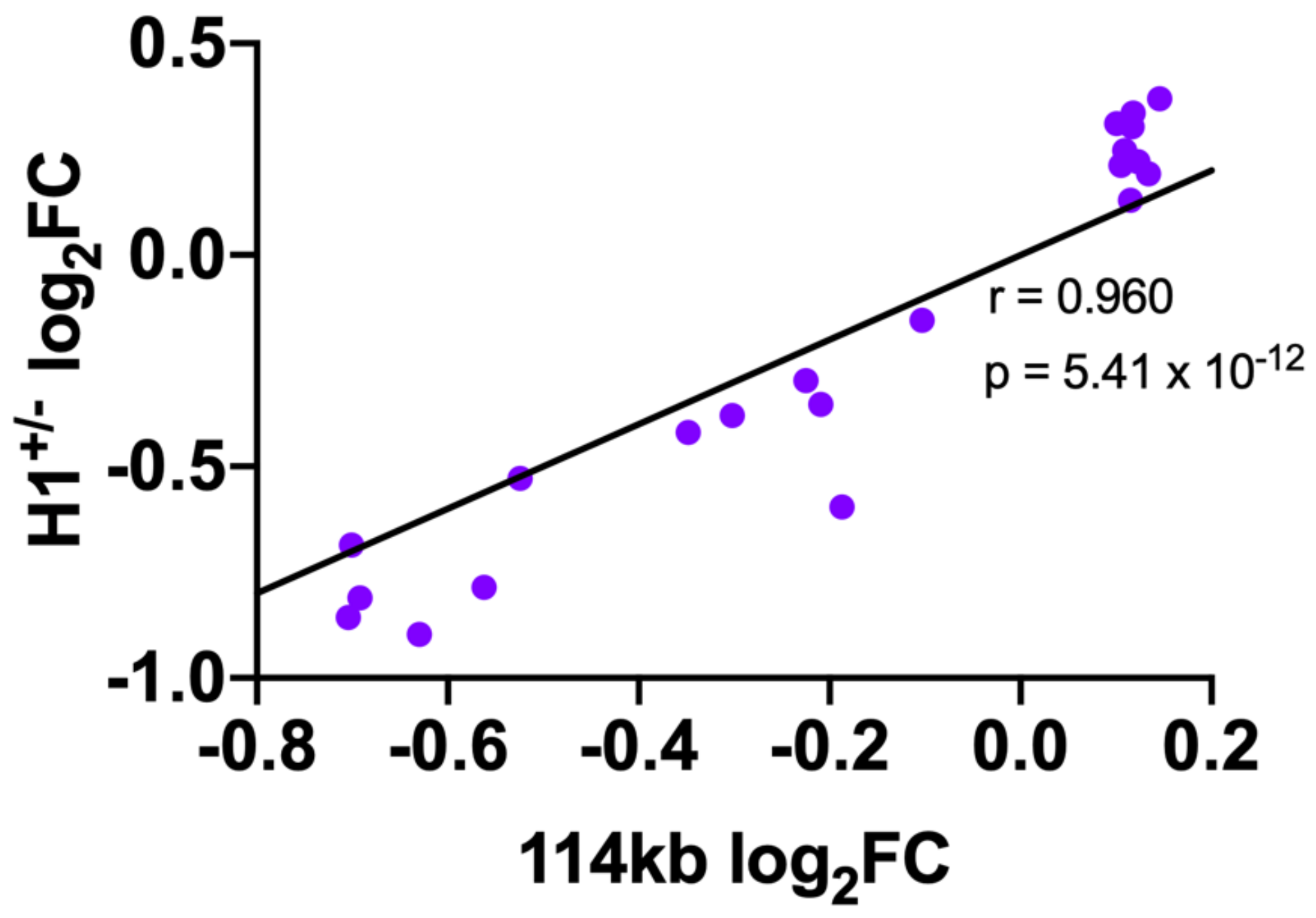


A

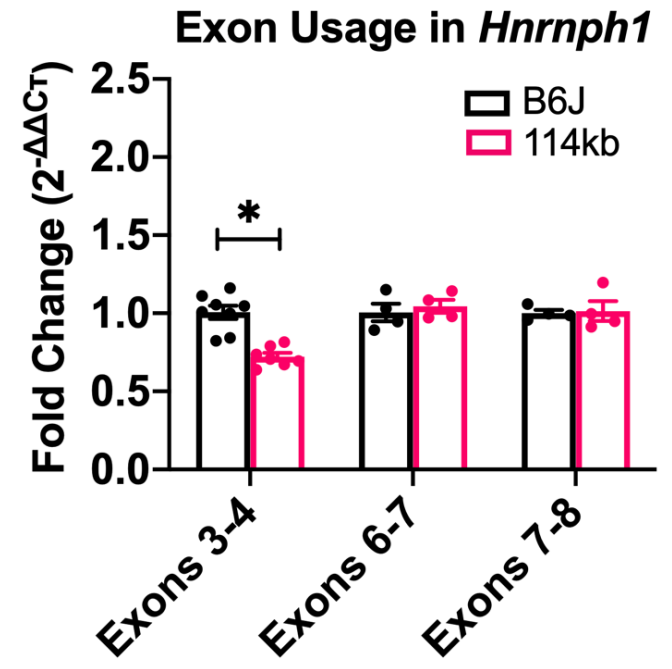

B
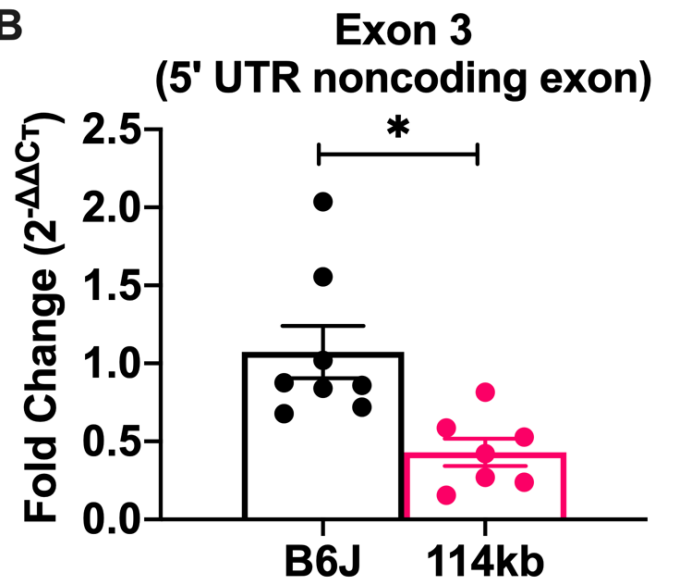

C

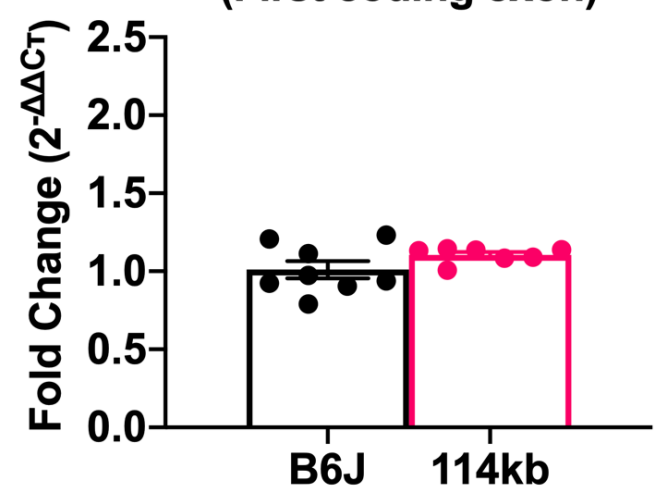


A $\square \square \square \square \square \square \square \square \square \square \square \square$
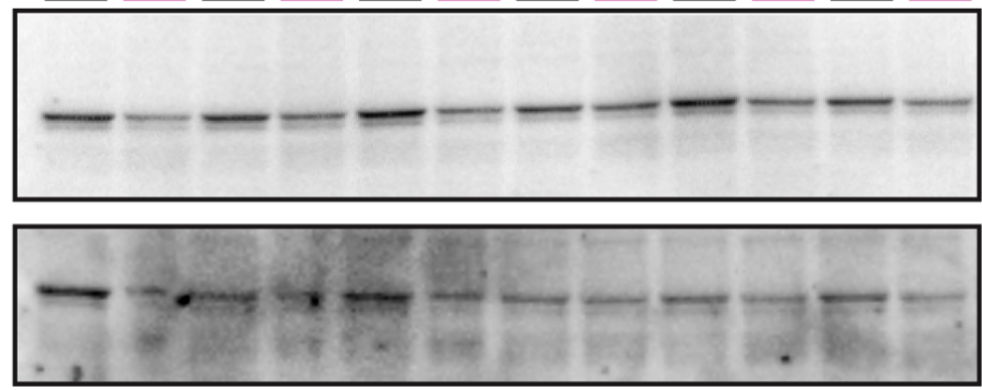

hnRNP H (Santa Cruz)

hnRNP H (Proteintech)
B

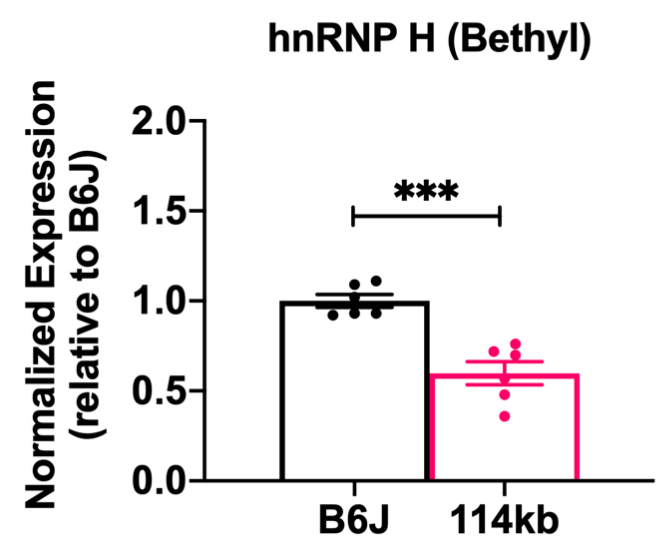

C

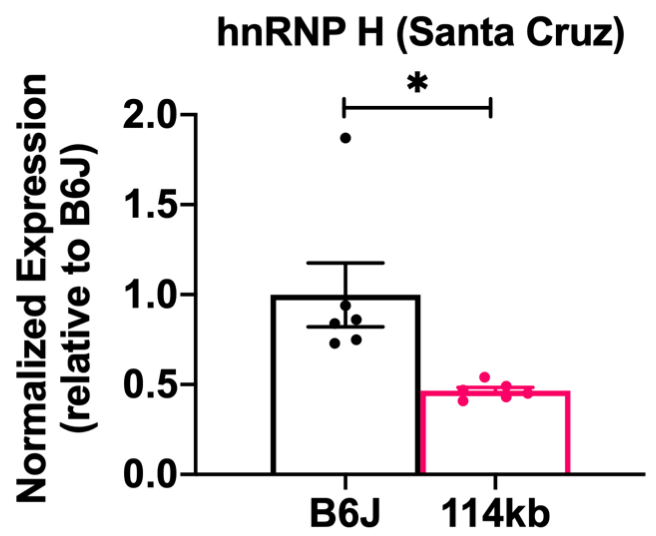

hnRNP H (Proteintech)

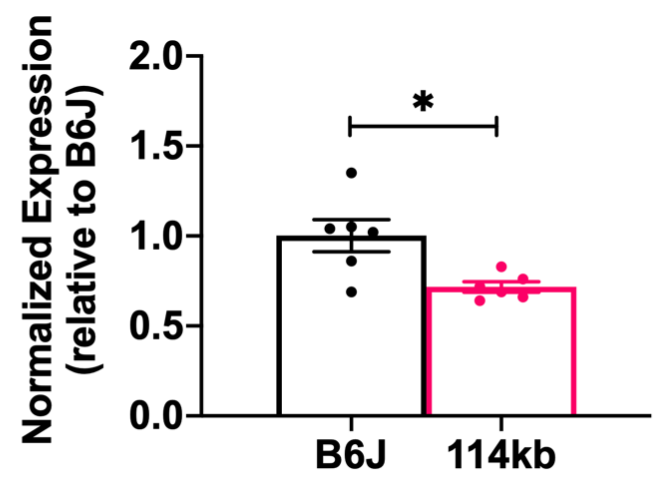


A $\quad|50,378,000| 50,379,000|50,380,000| 50,381,000|50,382,000| 50,383,000|50,384,000| 50,385,000 \mid 50,386,000$ |

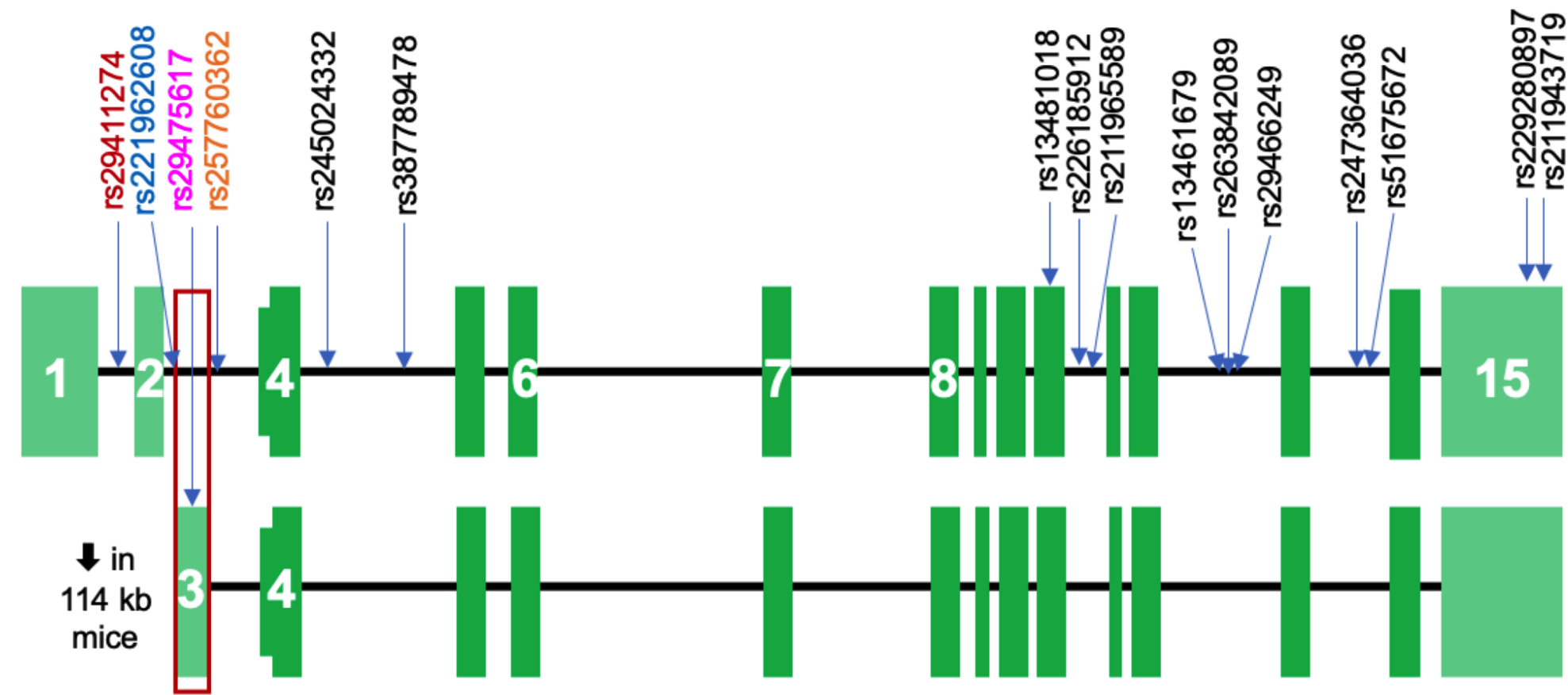

5'UTR

Coding regions

CTTCGCGCCCCTGGCAGTCTCAGCCTTCCCTCGCGAGGCGCCGCACACCG AGCGCCTCTCGTGCAAGGGCGAGGGGTTCGTAGAGTGCGAGTCCGTTAGG CAAAGTGGGGTACAGGACTAGCTCGGGCACTGGCAGCCCATGTGGGTCGG GACTGACCCCCTAAAGCGGGCAGGTAAGGGGACTGGTCCCAGGCGCCCCA CGGAGATCGGGGATTTGGGCGCAGGGGGCGGGGCGGTACCCAGAGGAGGT TTGGCACAACCCGGCCCTCCAGCTCCTACGCGTTCTGAGGAGAAAGGGCA TGGCTTCCTTTTCTTCGTGGTGTCTTTCAAAACCGACAGGAGCGCGGATG AAAAGCTGCGGATTAAGGGTAGAACTACCGCCCCTGCAAACCTGAACGAA CTCTGGATTACTACCCAGTCCCTGCGGGGAGCTGATTAGCGCCATTCCCC TCCCCCACTCCGGCGGGTAGGTCTAGAGAACGGTTTGAAGGTAGCCGCAT GCGCATTAAGTAAAACAAGAAACCGCTGAGACGCCAAGCGCAATAATTGC AAAAAGGCGCAGGCGCAGAAAGAAAAAAAAAAAACAACCAAAAACACCTC GGTCAGTTTATGAAGAGGGCTGAGCCCAAACGCATGCGTGTAATAATAGG ACGGCGGGAGAGAGCTCGGGGTTTCTTAATACGCATGCGTCCAATCTCTC TGTGACGCAAGTGGGGCGGGGCCGGCAACAGGGTGCGCGTGCGCAGAGCT TGCTGGAAGGGCTTTATTTAGCCTGCGCAGGCGCCCGCTTATCATTTCTC CTCAGCCACGCCGAGGCTTTITGTGGAGGTGAGTGACTTTCCGTCTTCGA CTGCTGCCCGAGCTCTCCACGGACACCTCTTTGGGTGACGATTGCTTGTC GCTGAGCTTAGGTTCTAACCTGAGGGGCCGTGGCAGGCGCAGGCTGCCCC TGGGAGCCGCGAGTGTCTCGCCGGCGTGGCAGCGCCGCCTAGGCCTGCAG
$50,377,024$ $50,377,074$ $50,377,124$ $50,377,174$ $50,377,224$ $50,377,274$ $50,377,324$ $50,377,374$ $50,377,424$ $50,377,475$ $50,377,524$ $50,377,574$ $50,377,624$ $50,377,674$ $50,377,724$ $50,377,774$ $50,377,824$ $50,377,874$ $50,377,924$ $50,377,974$ 


\section{A Hnrnph1 promoter (2956 bp) luc2 (1653 bp)}

B

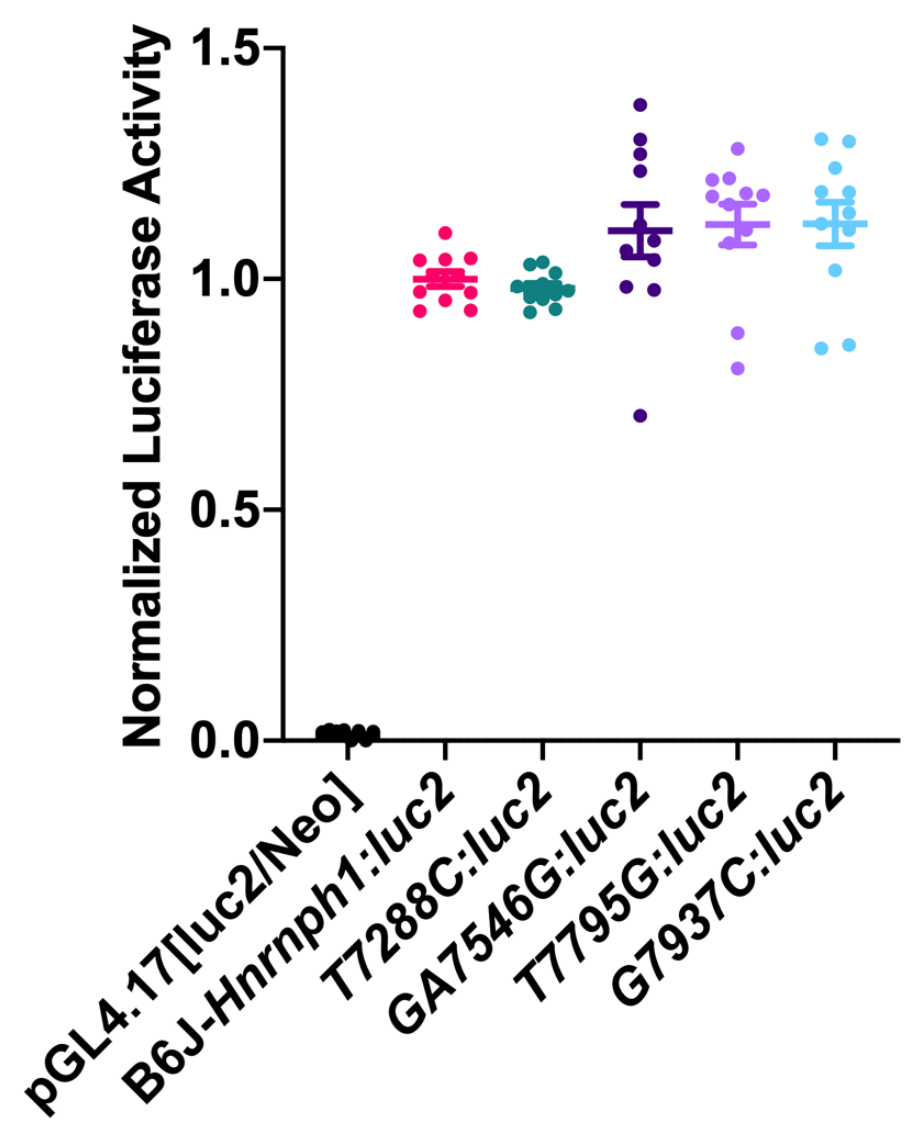

D

N2a

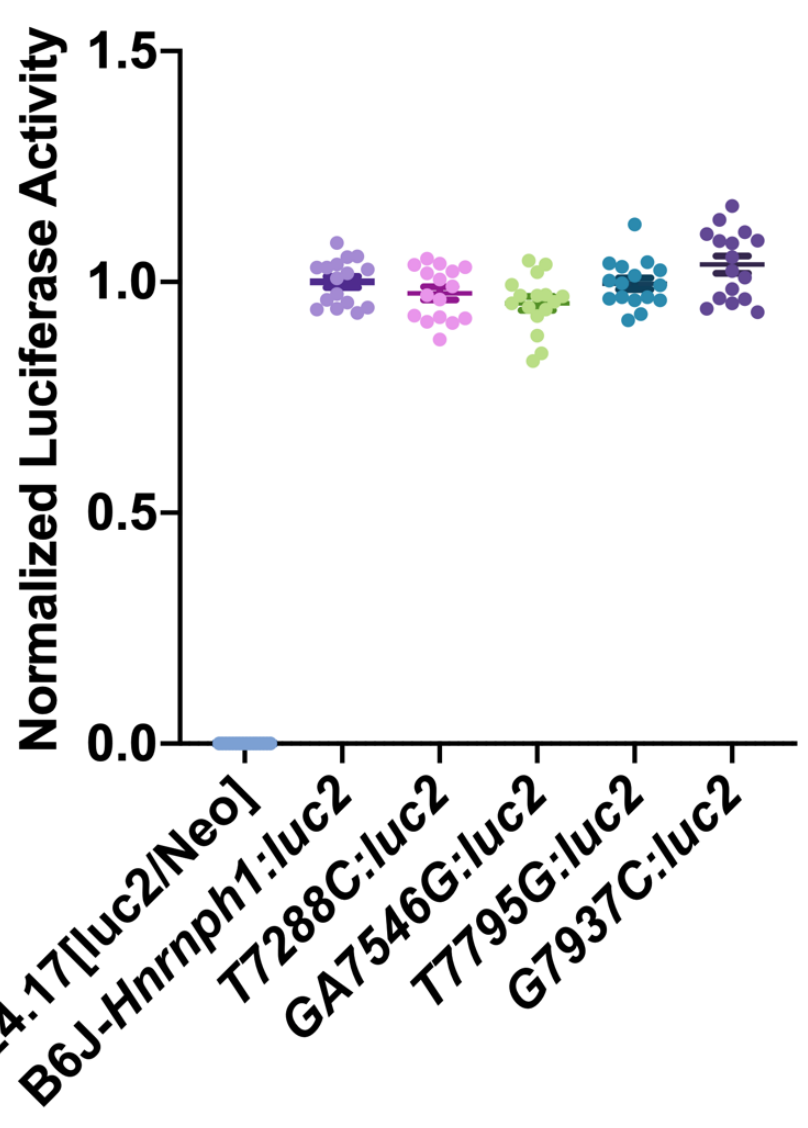

C

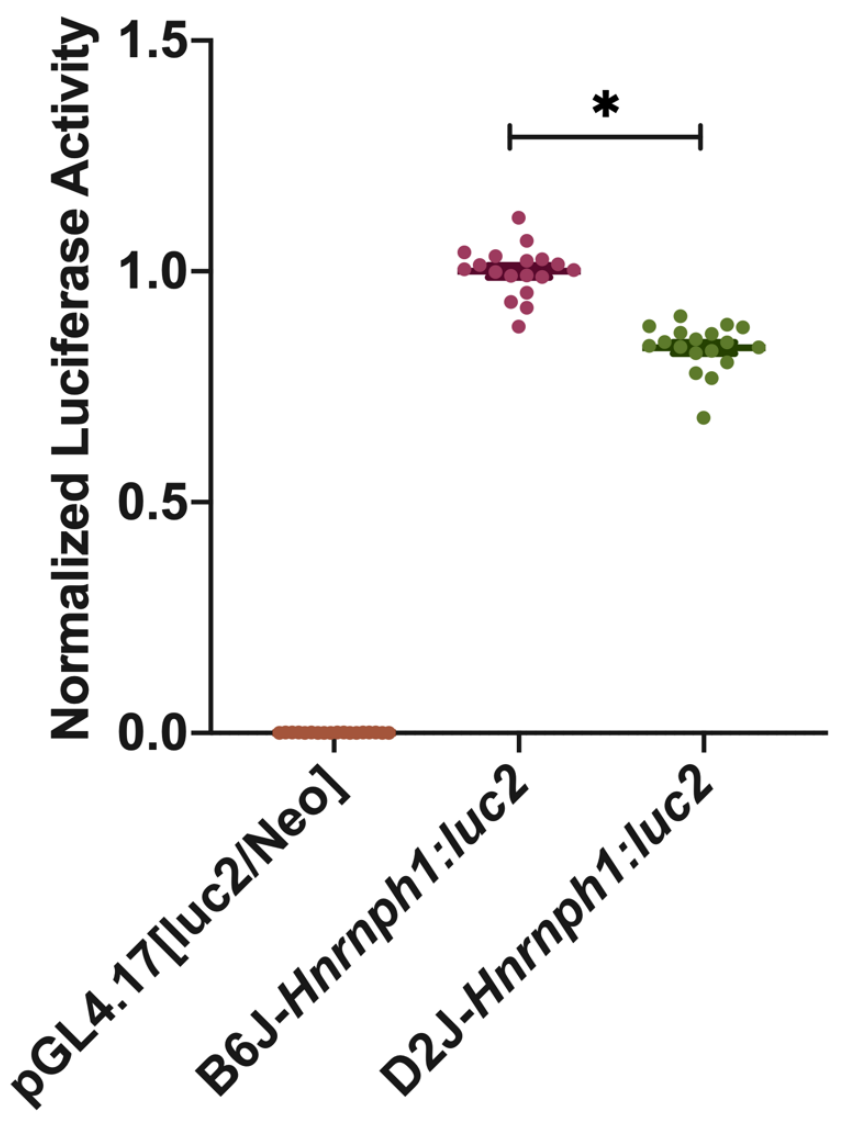

E

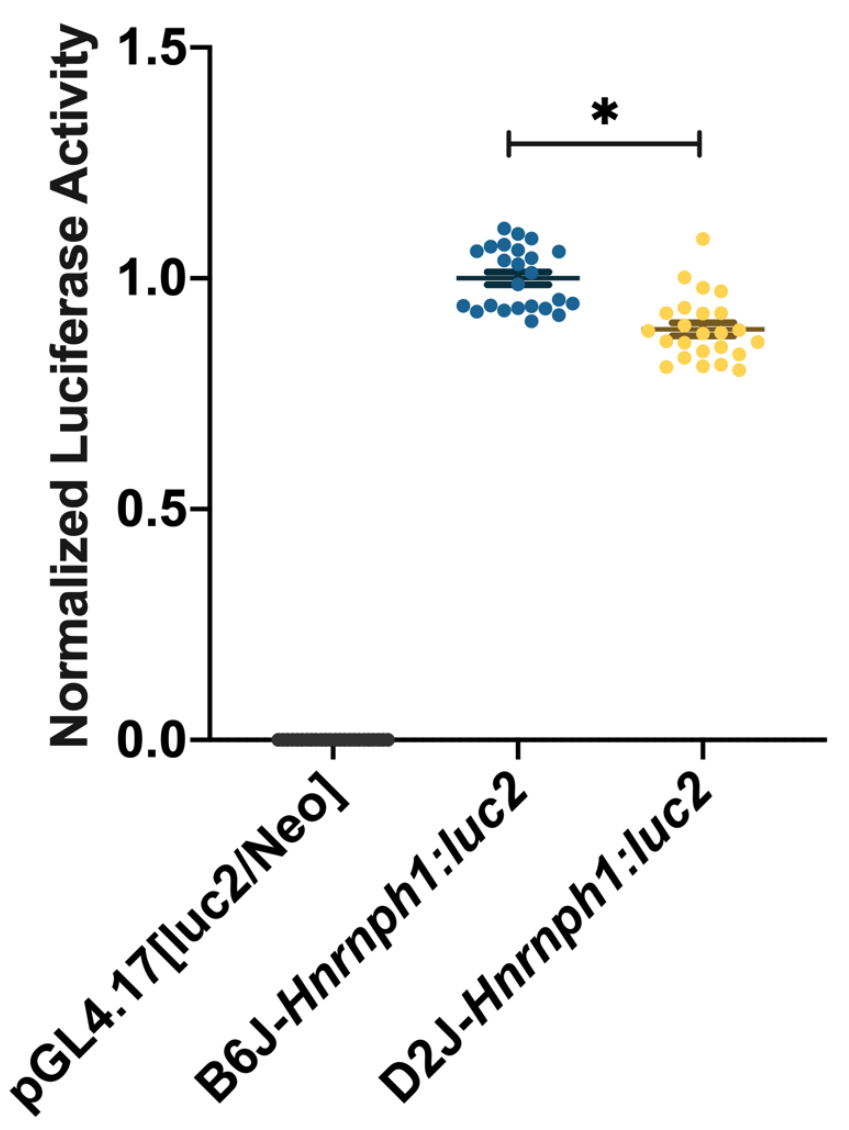




\section{Supplemental Data}

Supplemental Figure 1. Ponceau S staining for total protein normalization used in immunoblot quantification. Total protein stains via ponceau $\mathrm{S}$ instead of a housekeeping gene were used as loading controls. The densitometry value for the total protein stains in each lane is indicated below each immunoblot. These are the values that were used for normalization. (A-C): Ponceau $S$ total protein staining for quantification hnRNP H protein expression.

Supplemental Figure 2. DNA sequence of the cloned Hnrnph1 promoter. The promoter contains the DNA sequence 2956 bp upstream of transcription start site which corresponds to chromosome 11 nucleotide position $50,375,375$ to 50,378,330 ( $\mathrm{mm} 10)$. The nucleotides indicated in different colors represent the positions of the SNPs, and the nucleotides indicated in blue represent the positions of the indels. The exons are highlighted in green.

Supplemental Figure 3. Hnrnph1:luc2 reporter assay in HEK293T cells. (A): Schematic representation of the procedure for cloning the Hnrnphl promoter into pGL4.17[luc2/Neo]. The promoter region of Hnrnph1 was PCR-amplified followed by restriction enzyme digest by XhoI and HindIII for insertion into pGL4.17[luc2/Neo]. The Hnrnph1 promoter was defined as $2956 \mathrm{bp}$ upstream of the transcriptional start site of Hnrnphl and was fused to the firefly luciferase (luc2) to make the Hnrnphl:luc2 reporter. (B): Different numbers of HEK293T cells were seeded to determine whether the cloned Hnrnph1 promoter could drive expression of firefly luciferase, $l u c 2$. Firefly luminescence increased as the cell number increased [two-way ANOVA: $\mathrm{F}(3,16)=64.19, \mathrm{p}=3.86 \mathrm{E}-09$; Bonferroni's multiple comparison test: $\mathrm{t}(16)_{10,000}=1.15, \mathrm{p}>1$; $\left.\mathrm{t}(16)_{20,000}=2.94, * \mathrm{p}=0.005 ; \mathrm{t}(16)_{30,000}=8.35, * \mathrm{p}=1.25 \mathrm{e}-6 ; \mathrm{t}(16)_{50,000}=19.36, * \mathrm{p}=6.30 \mathrm{e}-12\right]$. Data are represented as the mean \pm S.E.M.

\section{Supplemental Table 1. RT-qPCR primers for exon usage.}

\section{Supplemental Table 2. Primers used for site directed mutagenesis.}

\section{Supplemental Table 3. Predicted RNA binding proteins (RBPs) associated with the 5' UTR of Hnrnph1.}

The 5' UTR Hnrnph1 sequence was loaded into RBPDB (61) where the sequence was scanned for putative sites for binding of RBPs. A list of RBPs that are predicted to bind to Hnrnphl and the binding sites on Hnrnph1 associated with the RBP are shown. The start and end positions refer to the nucleotide position for the sequence in Supplemental Figure 1. 


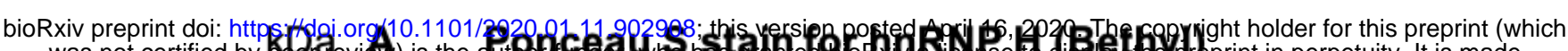

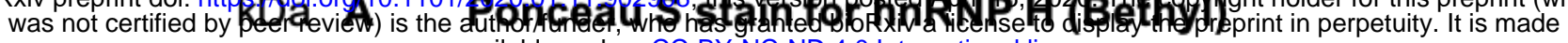

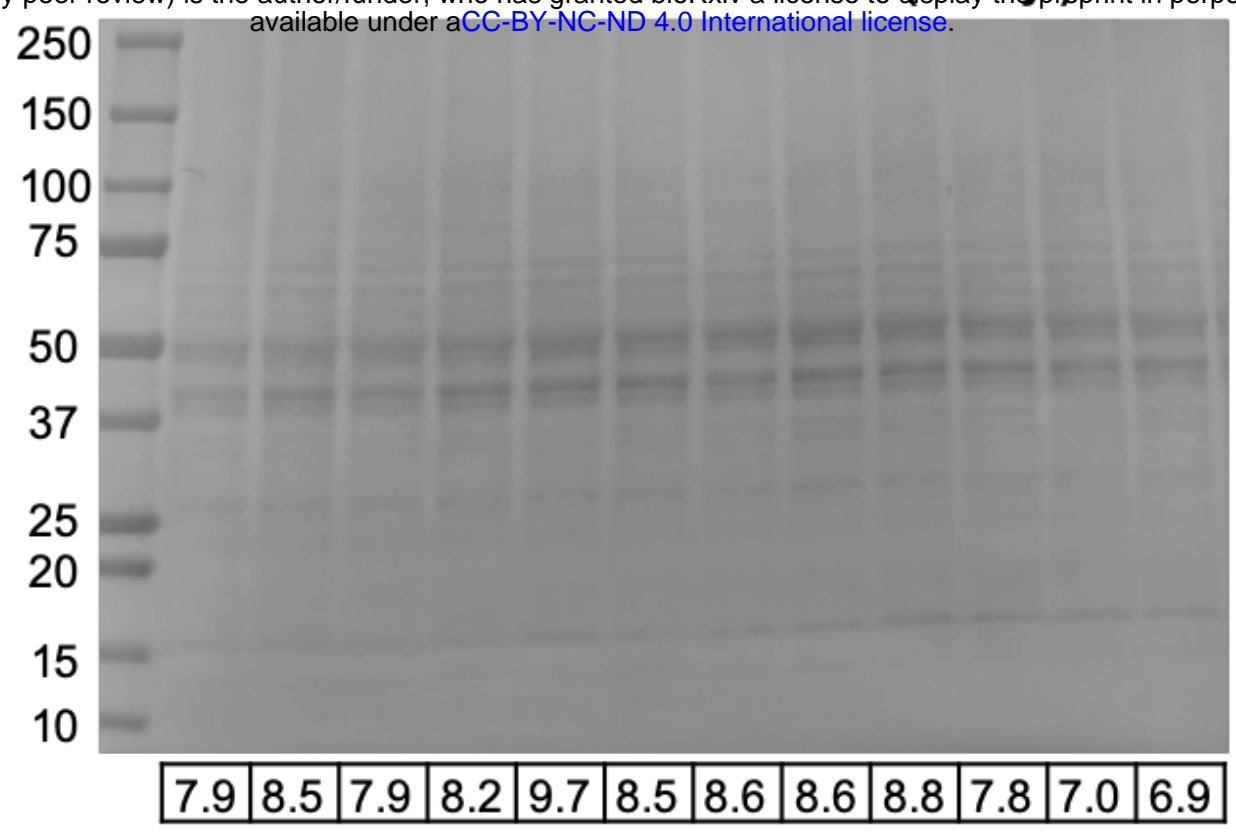

kDa B Ponceau S stain for hnRNP H (Santa Cruz) 250 150

100

75

50

37

25

20

15

10

\begin{tabular}{|l|l|l|l|l|l|l|l|l|l|l|l|}
\hline 8.0 & 6.7 & 7.2 & 9.0 & 8.5 & 8.2 & 6.8 & 7.9 & 8.1 & 8.6 & 7.7 & 7.9 \\
\hline
\end{tabular}

kDa C Ponceau S stain for hnRNP H (Proteintech)

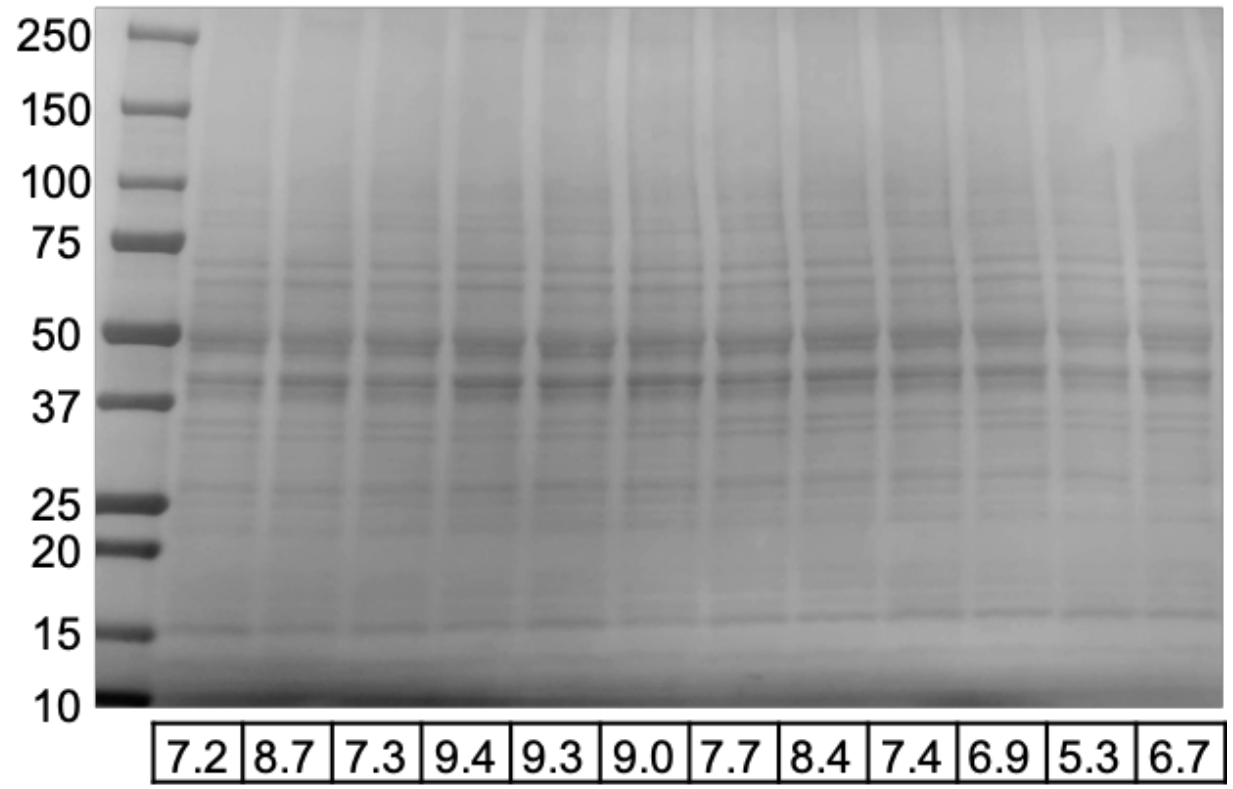




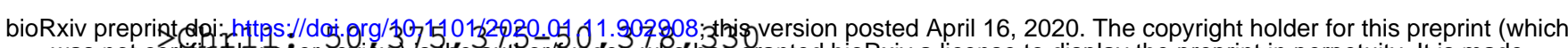
was not certified by peer reviews) is the author/funder, who has granted bioRxiv a license to display the preprint in perpetuity. It is made

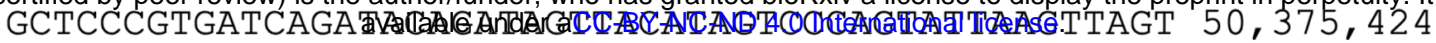

AAgGATTAAAAGAAAGGAAAgCCCATGTAGTGAAAGTCAGGCGTTTGCA 50, 375,474 GCCCTTGTACACAAAAGGATCTTCAAATCCTTCCATTGTTAGAAATTACA 50, 375, 524

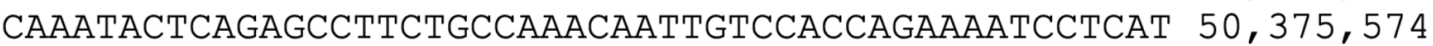
TGCGTGTGGTGGCACACACACTTTAATCCTGTCATTCTGGAGGCGGATGA 50, 375,624 TCAAACACTTGAGACCATGCATGACTGCAAGGGGAGTTTGAGGCCGGCCT 50, 375,674 GGGATGTGTGCAATCAGGACTCAAAACAATAAGGAAAGGACACAATAAGG 50, 375, 724 AAAGATAAAAGTTTTATCTATGATTATACACTGCATTTTTCTCTTACGA 50, 375,774 TGGAAAAATAACCTCCCATACAACTAGAATAGAATTTAGAGAAACATCGT 50, 375,824 AGGAATGTGGTTGTGTTGTCAGAAGGGAAACATTTCCCCCCCTTCAGGTG 50,375,874 AGAGACCTGGATTGCTAAGTTGCAGTGACTCTCCCATCTCAGCATCTCAA 50, 375, 924 GTAGATGGGACTACAGGCACATTACTGTGCAAAGTGAAAAAAGATGATTC 50, 375, 974 AAACAAAAAACGGTGTGTGTGTGTGAAAATATAGTTGAGTGGTAGGACTG 50, 376, 024 GTTTGCTCAAAGCCTTTCTAGTATGCATTGCTCTTCCCATACATCTAACC 50, 376, 074 AACGATCGCAGGTCATCTAATAAGTATAGGGCTCTCAAATGGTGTGAATT AGCTAAAGAAGAGTAATCTTAGTTTCTTGGTAATCAATCTCATGTCCCAA GACCATGTAGGGGGAAATATACATGTTAAGCAAGCTCTCTACCACTACTA TTTCTCTTGTCTTCTTTTTGAGACAGGCTTTCAGTAAATTTCCCAGGCTG CCTTGAACGCACTCTGTTGCTCAGGCAAGTCTTGAAGTTGCAGTTCTCCT CGGCTGGGCTTGTGTTCTTGCCTTTCACCCACCTCCTGGCCTGGAGACTT GGGAGTTCTCACTTTTCGATGATCTAAACTAGTGTTTTCTGTCTCCTCTA GATAGATCCTTTGCAGGTGAGGTCATGTGCAGTTATTCTCCCAGCCTGTC TCATCCGAGTTTCCCTTACACCTGAAGGTTCACGTTACACAGCTCCTGTT GCTCTCTTGAAGTCTTGTGATGCCCTTCTACTTAACACCCTTGCGCAGAC TTAAAAGGTCTGAGTTCTGCACGCAGTCTCTGCACCTTTCCTTTGATGAC ACCCCCСССTTTTAАAAAACAAACTGTTCAAACTGGATTTAGCCTCCTCA ATGTTGCACTTGAAAGAAAAGCGTATTTTTGCCTGTAACCTCTTGTGATG GCTTTCAGAGGCTTACCAATTGTGGTACCTACCGTGGCACCGCCCAAACA ATAACTCTTATTGTTAATTTCTAGGGTAGGTCAGTCAGATTCGGAGAAAC TCGGGACATCATCCGTATTCTGCTATGTTGCAGGAATTCTCTTAAACGTC ACCCATTTACCTCTGTAAGGGCACACGGGATGACCCGGGCGTGTCTCCAC CTTGGGAGAGGCCCGTTGGTCGGTCGGGCGCAGCGCTCTGGGGCTGCGTC CTTCGCGCCCCTGGCAGTCTCAGCCTTCCCTCGCGAGGCGCCGCACACCG AGCGCCTCTCGTGCAAGGGCGAGGGGTTCGTAGAGTGCGAGTCCGTTAGG CAAAGTGGGGTACAGGACTAGCTCGGGCACTGGCAGCCCATGTGGGTCGG GACTGACCCCCTAAAGCGGGCAGGTAAGGGGACTGGTCCCAGGCGCCCCA CGGAGATCGGGGATTTGGGCGCAGGGGGCGGGGCGGTACCCAGAGGAGGT TTGGCACAACCCGGCCCTCCAGCTCCTACGCGTTCTGAGGAGAAAGGGCA TGGCTTCCTTTTCTTCGTGGTGTCTTTCAAAACCGACAGGAGCGCGGATG AAAAGCTGCGGATTAAGGGTAGAACTACCGCCCCTGCAAACCTGAACGAA СTCTGGATTACTACCCAGTCCCTGCGGGGAGCTGATTAGCGCCATTCCCC TCCCCCACTCCGGCGGGTAGGTCTAGAGAACGGTTTGAAGGTAGCCGCAT GCGCATTAAGTAAAACAAGAAACCGCTGAGACGCCAAGCGCAATAATTGC AAAAAGGCGCAGGCGCAGAAAGAAAAAAAAAAAACAACCAAAAACACCTC GGTCAGTTTATGAAGAGGGCTGAGCCCAAACGCATGCGTGTAATAATAGG ACGGCGGGAGAGAGCTCGGGGTTTCTTAATACGCATGCGTCCAATCTCTC TGTGACGCAAGTGGGGCGGGGCCGGCAACAGGGTGCGCGTGCGCAGAGCT TGCTGGAAGGGCTTTATTTAGCCTGCGCAGGCGCCCGCTTATCATTTCTC СTCAGCCACGCCGAGGCTTTTTGTGGAGGTGAGTGACTTTCCGTCTTCGA CTGCTGCCCGAGCTCTCCACGGACACCTCTTTGGGTGACGATTGCTTGTC GCTGAGCTTAGGTTCTAACCTGAGGGGCCGTGGCAGGCGCAGGCTGCCCC TGGGAGCCGCGAGTGTCTCGCCGGCGTGGCAGCGCCGCCTAGGCCTGCAG GCCGCGCCGCTTTCTATTGTGTGAGATGTCTGAGGAGGCGGAGCGGAAGC GGCGGCCGCCATTTCCTCGTCTCAACCGTGGCTGTGGGCCAGGGTCTTAT TAGCTTGGCGCCTCGGCCCTGGGCGCACTGGGCGGCTTTGGGCATCGGGT CGCTAGCCGAGGCCGGGTTGCATGCTTGAGTCTCCGGGGCCCAGGCATCC TGACGGGCGGGACTCGCATGGCGGCGCCCGGTGCCCGCTGTGCGCCGTGA AGTGGGAGGGCCATTTAAATGCCTGTTTTCTCAGACGCGTTCCTGACCCC CACCCCCACCCCGCAGCCCCGCAATCTGTGTGGACGCCAGGACCACCGAA GGGACG $50,376,124$ $50,376,174$ $50,376,224$ $50,376,274$ $50,376,324$ $50,376,374$ $50,376,424$ $50,376,474$ $50,376,524$ $50,376,574$ $50,376,624$ $50,376,674$ $50,376,724$ $50,376,774$ $50,376,824$ $50,376,874$ $50,376,924$ $50,376,974$ $50,377,024$ $50,377,074$ $50,377,124$ $50,377,174$ $50,377,224$ $50,377,274$ $50,377,324$ $50,377,374$ $50,377,424$ $50,377,475$ $50,377,524$ $50,377,574$ $50,377,624$ $50,377,674$ $50,377,724$ $50,377,774$ $50,377,824$ $50,377,874$ $50,377,924$ $50,377,974$ $50,378,024$ $50,378,074$ $50,378,124$ $50,378,174$ $50,378,224$ $50,378,274$ $50,378,324$ $50,378,330$ 
A

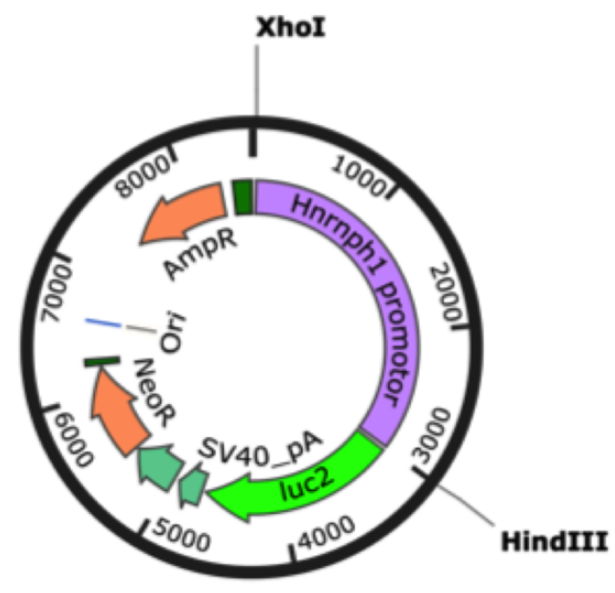

B6J-Hnrnph1:luc2
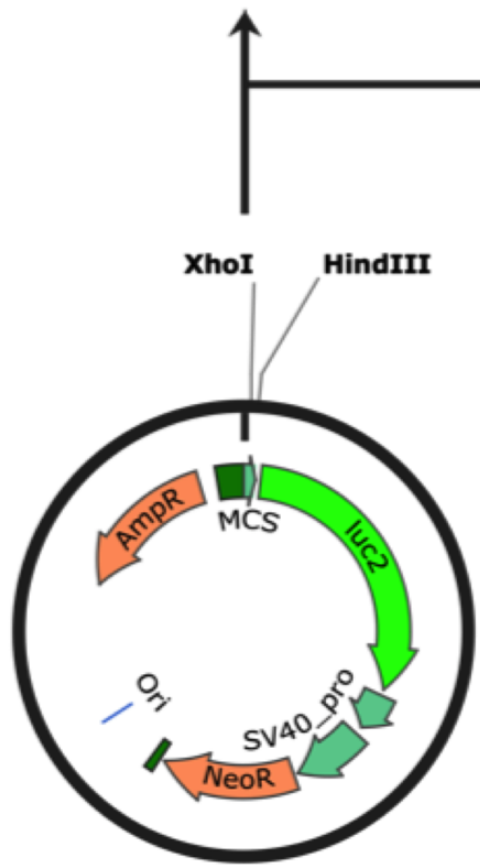

pGL4.17[luc2/Neo]
B

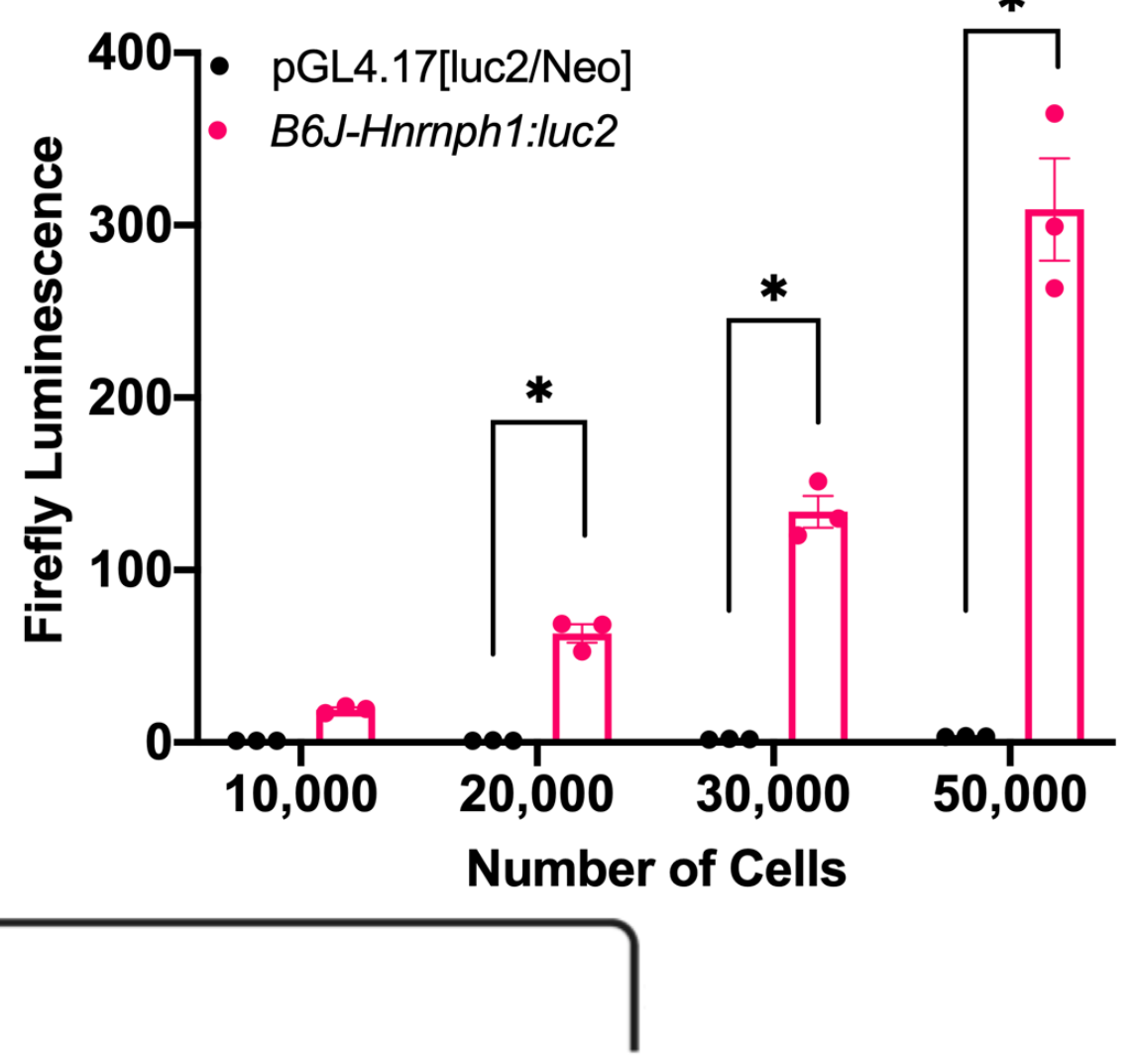


Supplemental Table 1. RT-qPCR primers for exon usage.

\begin{tabular}{|c|c|c|}
\hline Gene & $\begin{array}{c}\text { Targeted } \\
\operatorname{exon}(\mathbf{s})\end{array}$ & Sequences \\
\hline \multirow[t]{2}{*}{ Hnrnphl } & \multirow{2}{*}{$3-4$} & Forward: 5'-CGCCCGCTTATCATTTCTCC-3' \\
\hline & & Reverse: 5'-CTTCACCACGAAGCCCTCT-3' \\
\hline \multirow[t]{2}{*}{ Hnrnphl } & \multirow[t]{2}{*}{$6-7$} & Forward: 5'-ACGGCTTAGAGGACTCCCTTT-3' \\
\hline & & Reverse: 5'-CGTACTCCTCCCCTGGAAGT-3' \\
\hline \multirow[t]{2}{*}{ Hnrnphl } & \multirow[t]{2}{*}{$7-8$} & Forward: 5'-CAGGAAATAGCTGAAAAGGCTCTA-3' \\
\hline & & Reverse: 5'-GCCATAAGTTTTCGTGGTGG-3' \\
\hline \multirow[t]{2}{*}{ Hnrnphl } & \multirow[t]{2}{*}{3} & Forward: 5'-AGCTTGCTGGAAGGGCTT-3' \\
\hline & & Reverse: 5'-ACCTCCACAAAAAGCCTCG-3' \\
\hline \multirow[t]{2}{*}{ Hnrnphl } & \multirow[t]{2}{*}{4} & Forward: 5'-GACCACCGAAGGGACGAT-3' \\
\hline & & Reverse: 5'-AAAAAGCGCTGCACTTCATC-3' \\
\hline \multirow[t]{2}{*}{ GAPDH } & \multirow[t]{2}{*}{$5-6$} & Forward: 5'-GCCTTCCGTGTTCCTACC-3’' \\
\hline & & Reverse: 5'-CCTCAGTGTAGCCCAAGATG-3' \\
\hline
\end{tabular}


Supplemental Table 2. Primers used for site directed mutagenesis.

\begin{tabular}{|c|c|c|}
\hline \multirow[t]{2}{*}{ Mutation } & Position & \multirow[t]{2}{*}{ Mutagenesis primer Sequences } \\
\hline & SNP/Indel & \\
\hline \multirow[t]{2}{*}{$\mathrm{T} 7288 \mathrm{C}$} & $50,377,288$ & Forward: 5'-tgaaagacaccacgaggaaaaggaagccatgccc-3' \\
\hline & rs29411274 & Reverse: 5'-gggcatggcttccttttcctcgtggtgtctttca-3' \\
\hline \multirow[t]{2}{*}{ GA7546G } & $50,377,546$ & Forward: 5'-gtttttggttgtttttttttttctttctgcgcctgcgcetttt-3' \\
\hline & rs221962608 & Reverse: 5'-aaaaggcgcaggcgcagaaagaaaaaaaaaaacaaccaaaaac-3' \\
\hline \multirow[t]{2}{*}{ T7795G } & $50,377,795$ & Forward: 5'-cacctccacacaaagcctcggcgtggctga-3' \\
\hline & rs29475617 & Reverse: 5'-tcagccacgccgaggctttgtgtggaggtg-3' \\
\hline \multirow[t]{2}{*}{ G7937C } & $50,377,937$ & Forward: 5'-cggcgagacagtcgcggctccca-3' \\
\hline & rs 257760362 & Reverse: 5'-tgggagccgcgactgtctcgccg-3' \\
\hline \multirow{6}{*}{$\begin{array}{c}\text { All four } \\
\text { mutations } \\
\text { (GA7546G:luc2 } \\
\text { mutant used as } \\
\text { template for } \\
\text { multi-site } \\
\text { mutagenesis) }\end{array}$} & & Forward1: 5'-gggcatggcttccttttcctcgtggtgtctttca-3' \\
\hline & & Reverse1: 5'-tgaaagacaccacgaggaaaaggaagccatgccc-3' \\
\hline & & Forward2: 5'-tcagccacgccgaggctttgtgtggaggtg-3' \\
\hline & & Reverse2: 5'-cacctccacacaaagcctcggcgtggctga-3' \\
\hline & & Forward3: 5'-tgggagccgcgactgtctcgecg-3' \\
\hline & & Reverse3: 5'-cggcgagacagtcgcggctccca-3' \\
\hline
\end{tabular}


Supplemental Table 3. Predicted RNA binding proteins (RBPs) associated with the 5' UTR of Hnrnph1. The 5' UTR Hnrnphl sequence was loaded into RBPDB (61) where the sequence was scanned for putative sites for binding of RBPs. A list of RBPs that are predicted to bind to Hnrnphl and the binding sites on Hnrnphl associated with the RBP are shown. The start and end positions refer to the nucleotide position for the sequence in Supplemental Figure 1.

\begin{tabular}{|c|c|c|c|}
\hline RBP & Start & End & Matching sequence \\
\hline ZFP36 & 328 & 338 & AAUAAGGAAAG \\
\hline ZFP36 & 344 & 354 & AAUAAGGAAAG \\
\hline KHSRP & 1252 & 1259 & СCCСCCCC \\
\hline A2BP1 & 268 & 273 & UGCAUG \\
\hline A2BP1 & 2769 & 2774 & UGCAUG \\
\hline ZRANB2 & 1772 & 1777 & AGGUAA \\
\hline HNRNPA1 & 1422 & 1427 & UAGGGU \\
\hline$y b \times 2-a$ & 443 & 448 & AACAUC \\
\hline$y b \times 2-a$ & 443 & 448 & AACAUC \\
\hline EIF4B & 2807 & 2813 & GCGGGAC \\
\hline NONO & 2950 & 2954 & AGGGA \\
\hline NONO & 65 & 69 & AGGGA \\
\hline NONO & 474 & 478 & AGGGA \\
\hline sap-49 & 742 & 747 & GUGUGA \\
\hline sap-49 & 2619 & 2624 & GUGUGA \\
\hline sap-49 & 621 & 626 & GUGUGA \\
\hline PABPC1 & 605 & 609 & AAAAA \\
\hline PABPC1 & 2151 & 2155 & AAAAA \\
\hline PABPC1 & 2180 & 2184 & AAAAA \\
\hline PABPC1 & 2173 & 2177 & AAAAA \\
\hline PABPC1 & 2179 & 2183 & AAAAA \\
\hline PABPC1 & 2190 & 2194 & AAAAA \\
\hline PABPC1 & 2178 & 2182 & AAAAA \\
\hline PABPC1 & 588 & 592 & AAAAA \\
\hline PABPC1 & 587 & 591 & AAAAA \\
\hline PABPC1 & 2175 & 2179 & AAAAA \\
\hline PABPC1 & 2177 & 2181 & AAAAA \\
\hline PABPC1 & 2174 & 2178 & AAAAA \\
\hline PABPC1 & 1264 & 1268 & AAAAA \\
\hline PABPC1 & 606 & 610 & AAAAA \\
\hline PABPC1 & 2176 & 2180 & AAAAA \\
\hline PABPC1 & 1265 & 1269 & AAAAA \\
\hline PABPC1 & 404 & 408 & AAAAA \\
\hline RBMY1A1 & 546 & 550 & CUCAA \\
\hline
\end{tabular}




\begin{tabular}{|c|c|c|c|}
\hline RBMY1A1 & 2671 & 2675 & CUCAA \\
\hline RBMY1A1 & 320 & 324 & CUCAA \\
\hline RBMY1A1 & 656 & 660 & CUCAA \\
\hline RBMY1A1 & 1297 & 1301 & CUCAA \\
\hline RBMY1A1 & 734 & 738 & CUCAA \\
\hline a2bp1 & 2816 & 2820 & GCAUG \\
\hline a2bp1 & 2770 & 2774 & GCAUG \\
\hline a2bp1 & 2232 & 2236 & GCAUG \\
\hline a2bp1 & 269 & 273 & GCAUG \\
\hline a2bp1 & 2097 & 2101 & GCAUG \\
\hline a2bp1 & 2283 & 2287 & GCAUG \\
\hline a2bp1 & 1898 & 1902 & GCAUG \\
\hline RBMY1A1 & 546 & 550 & CUCAA \\
\hline RBMY1A1 & 2671 & 2675 & CUCAA \\
\hline RBMY1A1 & 320 & 324 & CUCAA \\
\hline RBMY1A1 & 656 & 660 & CUCAA \\
\hline RBMY1A1 & 1297 & 1301 & CUCAA \\
\hline RBMY1A1 & 734 & 738 & CUCAA \\
\hline EIF4B & 449 & 455 & GUAGGAA \\
\hline PABPC1 & 150 & 156 & ACAAAUA \\
\hline RBMY1A1 & 341 & 345 & CACAA \\
\hline RBMY1A1 & 1855 & 1859 & CACAA \\
\hline RBMY1A1 & 110 & 114 & CACAA \\
\hline RBMY1A1 & 149 & 153 & CACAA \\
\hline sap-49 & 1165 & 1170 & UUGUGA \\
\hline sap-49 & 1343 & 1348 & UUGUGA \\
\hline FUS & 208 & 211 & GGUG \\
\hline FUS & 2484 & 2487 & GGUG \\
\hline FUS & 2332 & 2335 & GGUG \\
\hline FUS & 2428 & 2431 & GGUG \\
\hline FUS & 1066 & 1069 & GGUG \\
\hline FUS & 497 & 500 & GGUG \\
\hline FUS & 2830 & 2833 & GGUG \\
\hline FUS & 612 & 615 & GGUG \\
\hline FUS & 741 & 744 & GGUG \\
\hline FUS & 1919 & 1922 & GGUG \\
\hline Pum2 & 106 & 109 & UGUA \\
\hline Pum2 & 77 & 80 & UGUA \\
\hline Pum2 & 1334 & 1337 & UGUA \\
\hline
\end{tabular}




\begin{tabular}{|c|c|c|c|}
\hline Pum2 & 806 & 809 & UGUA \\
\hline Pum2 & 2239 & 2242 & UGUA \\
\hline Pum2 & 1514 & 1517 & UGUA \\
\hline SNRPA & 1303 & 1309 & GUUGCAC \\
\hline SFRS9 & 316 & 320 & AGGAC \\
\hline SFRS9 & 337 & 341 & AGGAC \\
\hline SFRS9 & 1714 & 1718 & AGGAC \\
\hline SFRS9 & 2248 & 2252 & AGGAC \\
\hline SFRS9 & 2939 & 2943 & AGGAC \\
\hline SFRS9 & 644 & 648 & AGGAC \\
\hline ACO1 & 523 & 528 & CAGUGA \\
\hline SFRS9 & 1888 & 1892 & AGGAG \\
\hline SFRS9 & 1844 & 1848 & AGGAG \\
\hline SFRS9 & 2633 & 2637 & AGGAG \\
\hline SFRS9 & 1938 & 1942 & AGGAG \\
\hline MBNL1 & 513 & 516 & UGCU \\
\hline MBNL1 & 918 & 921 & UGCU \\
\hline MBNL1 & 2351 & 2354 & UGCU \\
\hline MBNL1 & 679 & 682 & UGCU \\
\hline MBNL1 & 654 & 657 & UGCU \\
\hline MBNL1 & 1471 & 1474 & UGCU \\
\hline MBNL1 & 2493 & 2496 & UGCU \\
\hline MBNL1 & 2452 & 2455 & UGCU \\
\hline MBNL1 & 1150 & 1153 & UGCU \\
\hline MBNL1 & 2773 & 2776 & UGCU \\
\hline EIF4B & 2355 & 2358 & GGAA \\
\hline EIF4B & 1483 & 1486 & GGAA \\
\hline EIF4B & 452 & 455 & GGAA \\
\hline EIF4B & 476 & 479 & GGAA \\
\hline EIF4B & 2645 & 2648 & GGAA \\
\hline EIF4B & 402 & 405 & GGAA \\
\hline EIF4B & 67 & 70 & GGAA \\
\hline EIF4B & 349 & 352 & GGAA \\
\hline EIF4B & 333 & 336 & GGAA \\
\hline EIF4B & 813 & 816 & GGAA \\
\hline KHSRP & 1786 & 1789 & GUCC \\
\hline KHSRP & 1598 & 1601 & GUCC \\
\hline KHSRP & 181 & 184 & GUCC \\
\hline KHSRP & 32 & 35 & GUCC \\
\hline
\end{tabular}




\begin{tabular}{|c|c|c|c|}
\hline KHSRP & 2289 & 2292 & GUCC \\
\hline KHSRP & 2018 & 2021 & GUCC \\
\hline KHSRP & 794 & 797 & GUCC \\
\hline KHSRP & 1691 & 1694 & GUCC \\
\hline YBX1 & 2021 & 2026 & CCUGCG \\
\hline YBX1 & 2372 & 2377 & CCUGCG \\
\hline MBNL1 & 2751 & 2754 & CGCU \\
\hline MBNL1 & 2608 & 2611 & CGCU \\
\hline MBNL1 & 2500 & 2503 & CGCU \\
\hline MBNL1 & 1584 & 1587 & CGCU \\
\hline MBNL1 & 2386 & 2389 & CGCU \\
\hline MBNL1 & 2836 & 2839 & CGCU \\
\hline MBNL1 & 2124 & 2127 & CGCU \\
\hline Vts1 & 2597 & 2603 & GCAGGCC \\
\hline YTHDC1 & 2277 & 2282 & UAAUAC \\
\hline YTHDC1 & 2770 & 2775 & GCAUGC \\
\hline YTHDC1 & 2232 & 2237 & GCAUGC \\
\hline YTHDC1 & 2097 & 2102 & GCAUGC \\
\hline YTHDC1 & 2283 & 2288 & GCAUGC \\
\hline Vts1 & 2377 & 2383 & GCAGGCG \\
\hline Vts1 & 2159 & 2165 & GCAGGCG \\
\hline Vts1 & 2533 & 2539 & GCAGGCG \\
\hline Vts1 & 1766 & 1772 & GCGGGCA \\
\hline YBX1 & 1593 & 1598 & GCUGCG \\
\hline YBX1 & 1955 & 1960 & GCUGCG \\
\hline YTHDC1 & 1683 & 1688 & GAGUGC \\
\hline Vts1 & 2539 & 2545 & GCAGGCU \\
\hline Vts1 & 2807 & 2813 & GCGGGAC \\
\hline Vts1 & 1828 & 1834 & GCGGGGC \\
\hline Vts1 & 2316 & 2322 & GCGGGGC \\
\hline QKI & 2513 & 2522 & UUCUAACCUG \\
\hline YTHDC1 & 2337 & 2342 & GCGUGC \\
\hline RBMX & 2937 & 2940 & CCAG \\
\hline RBMX & 893 & 896 & $\mathrm{CCAG}$ \\
\hline RBMX & 2015 & 2018 & $\mathrm{CCAG}$ \\
\hline RBMX & 1789 & 1792 & CCAG \\
\hline RBMX & 1840 & 1843 & CCAG \\
\hline RBMX & 2689 & 2692 & $\mathrm{CCAG}$ \\
\hline RBMX & 1091 & 1094 & CCAG \\
\hline
\end{tabular}


bioRxiv preprint doi: https://doi.org/10.1101/2020.01.11.902908; this version posted April 16, 2020. The copyright holder for this preprint (which was not certified by peer review) is the author/funder, who has granted bioRxiv a license to display the preprint in perpetuity. It is made available under aCC-BY-NC-ND 4.0 International license.

\begin{tabular}{|c|c|c|c|}
\hline RBMX & 1869 & 1872 & CCAG \\
\hline RBMX & 35 & 38 & CCAG \\
\hline RBMX & 2791 & 2794 & CCAG \\
\hline RBMX & 186 & 189 & CCAG \\
\hline SFRS13A & 335 & 341 & AAAGGAC \\
\hline SFRS13A & 1893 & 1899 & AAAGGGC \\
\hline
\end{tabular}

